Andrews University

Digital Commons @ Andrews University

\title{
A Strategy for the Motivation of the Uninvolved Church Member: A Pilot Project in the Gloucester Seventh-day Adventist Church
}

Michael G. Hamilton

Andrews University

Follow this and additional works at: https://digitalcommons.andrews.edu/dmin

Part of the Practical Theology Commons

\section{Recommended Citation}

Hamilton, Michael G., "A Strategy for the Motivation of the Uninvolved Church Member: A Pilot Project in the Gloucester Seventh-day Adventist Church" (2005). Professional Dissertations DMin. 695.

https://dx.doi.org/10.32597/dmin/695

https://digitalcommons.andrews.edu/dmin/695

This Project Report is brought to you for free and open access by the Graduate Research at Digital Commons @ Andrews University. It has been accepted for inclusion in Professional Dissertations DMin by an authorized administrator of Digital Commons @ Andrews University. For more information, please contact repository@andrews.edu. 


\begin{abstract}
STRATEGY FOR THE MOTIVATION OF THE UNINVOLVED CHURCH MEMBER: A PILOT PROJECT IN THE GLOUCESTER SEVENTH-DAY

ADVENTIST CHURCH
\end{abstract}

By

Michael G. Hamilton

Advisers: Bruce L. Bauer, Rudi Maier 


\title{
ABSTRACT OF GRADUATE STUDENT RESEARCH
}

Dissertation

\author{
Andrews University
}

Seventh-day Adventist Theological Seminary

\section{Title: STRATEGY FOR THE MOTIVATION OF THE UNINVOLVED CHURCH MEMBER: A PILOT STUDY IN THE GLOUCESTER SEVENTH-DAY ADVENTIST CHURCH}

Name of researcher: Michael G. Hamilton

Name and degree of faculty advisers: Bruce Bauer, D.Miss., and Rudi Maier, Ph.D.

Date completed: June 2005

\section{Problem}

In the average Seventh-day Adventist church in the South England Conference the pastor is often not equipped with the time and the resources to conduct an adequate training and education program for the uninvolved member. Spiritual Gifts seminars, outreach, and witnessing seminars are often conducted away from the local church and are largely supported only by those who are already deeply committed, but the shy, introverted, and uninformed member is increasingly uninvolved in the work of soul 
winning and the local ministries, and is not involved in the training activities of the church.

\section{Method}

A church involvement survey was conducted in three churches to measure the level of involvement and to gather data necessary for the completion of the project. Literature review on the subject of lay involvement was conducted, and a strategy of conducting a series of seminars to increase knowledge of personality types and spiritual gifts was developed. A seminar in understanding God's values and personal values was conducted for the purpose of a positive change of attitude toward involvement in local ministry. Training seminars will be conducted to prepare local leaders to mentor uninvolved members into more involvement in local ministries.

\section{Results}

Despite time and budgetary restraints three seminars were completed with an average of twenty persons attending each seminar. Evaluations of seminars indicate positive results in the change of attitude of the participants. The project is ongoing and the local church board is supportive of the project.

\section{Conclusions}

Uninvolved church members generally need personal invitations to participate in training events. However, the vast majority of members are keen to be trained to become more involved in local church ministries. The success of this project is dependent on other factors relating to the general health of the local church and its ministry structures. 
Andrews University

Seventh-day Adventist Theological Seminary

\title{
A STRATEGY FOR THE MOTIVATION OF THE UNINVOLVED CHURCH MEMBER: A PILOT PROJECT IN THE GLOUCESTER SEVENTH-DAY \\ ADVENTIST CHURCH
}

\author{
A Dissertation \\ Presented in Partial Fulfillment \\ of the Requirements for the Degree \\ Doctor of Ministry
}

by

Michael G. Hamilton

June 2005 


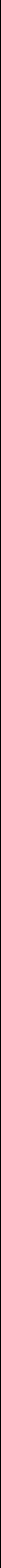




\title{
A STRATEGY FOR THE MOTIVATION OF THE UNINVOLVED CHURCH MEMBER: A PILOT PROJECT IN THE GLOUCESTER SEVENTH-DAY ADVENTIST CHURCH
}

\author{
A dissertation \\ presented in partial fulfillment \\ of the requirements for the degree \\ Doctor of Ministry
}

By

Michael G. Hamilton

APPROVAL BY THE COMMITTEE:

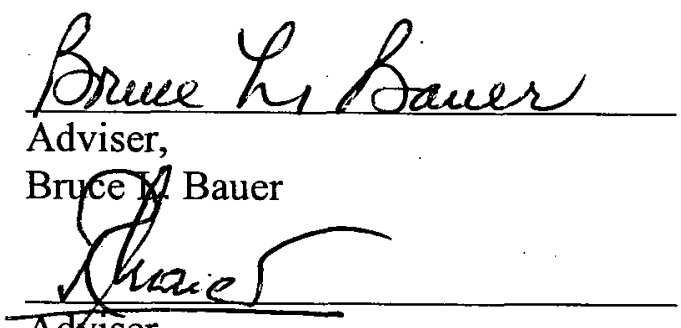

Adviser, Rudi Maier

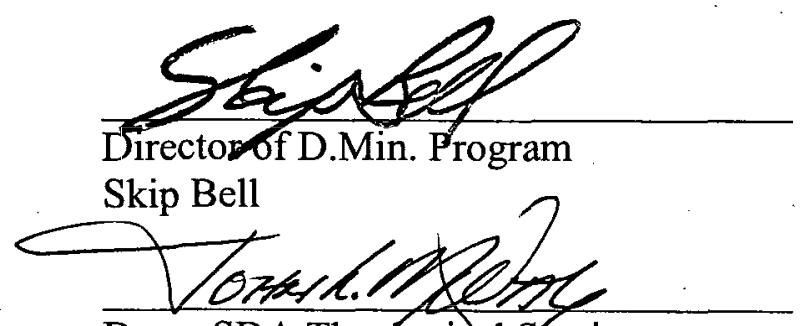

Dean, SDA Theologicalseminary John K. McVay

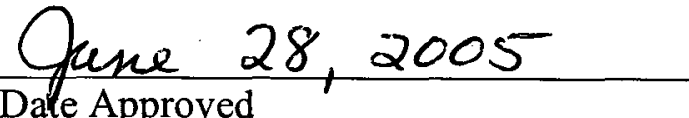




\section{TABLE OF CONTENTS}

LIST OF FIGURES $\quad \ldots \ldots \ldots \ldots \ldots \ldots \ldots \ldots \ldots \ldots \ldots \ldots \ldots$

LIST OF TABLES $\ldots \ldots \ldots \ldots \ldots \ldots \ldots \ldots \ldots \ldots \ldots \ldots \ldots$

LIST OF ABBREVIATIONS $\ldots \ldots \ldots \ldots \ldots \ldots \ldots \ldots$ vii

ACKNOWLEDGMENTS $\ldots \ldots \ldots \ldots \ldots \ldots \ldots \ldots$ viii

Chapter

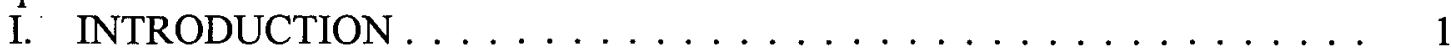

Problem ..................... 1

Justification . . . . . . . . . . . . 2

Definitions..................... 3

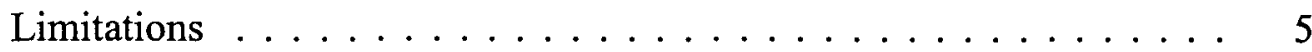

Methodology .................. 6

II. PERSONAL, SPIRITUAL, AND THEOLOGICAL FOUNDATION FOR

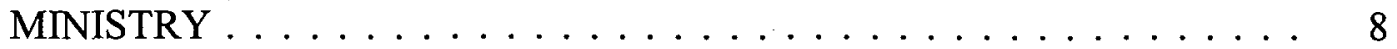

Personal Profile . . . . . . . . . . . . . . . . . . 8

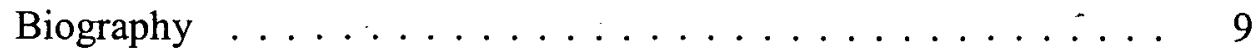

Present Ministry Situation . . . . . . . . . . . . . 16

Personality . . . . . . . . . . . . . . . . . . 19

Temperament . . . . . . . . . . . . . . 19

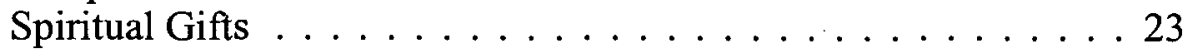

Leadership/Interaction Style . . . . . . . . . . . . . . . 2 24

Spirituality Web . . . . . . . . . . . . . . . 25

Task Type Preference . . . . . . . . . . . . . . . 227

Personal and Spiritual Goals . . . . . . . . . . . . . . . . . 27

Need for Self-Assessment . . . . . . . . . . . . . . . . 27

Deeper Personal Study of the Scriptures . . . . . . . . . . . . . 34

Consistent Personal Prayer Life . . . . . . . . . . . . . . . . 37

Practice of Meditation. . . . . . . . . . . . . . . . 40

Learning from Jesus. . . . . . . . . . . . . . . . .41

Theological Understanding . . . . . . . . . . . . . . . . . . 42

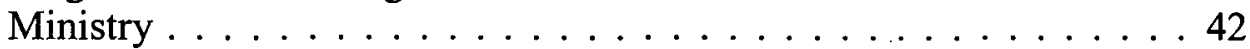

Jesus' Ministry . . . . . . . . . . . . . . . . . 42

New Testament. . . . . . . . . . . . . . . . . 43

Ministry and Mission $\ldots \ldots \ldots \ldots \ldots \ldots \ldots 44$ 
Church . . . . . . . . . . . . . . . . . . 49

Concept of Church in the Old Testament. . . . . . . . . . . 50 50

Concept of Church in the New Testament . . . . . . . . . . . 52

Personal Reflection . . . . . . . . . . . . . . . 55

III. RELIGIOUS AND CULTURAL ANALYSIS. . . . . . . . . . . . . . . . . 59

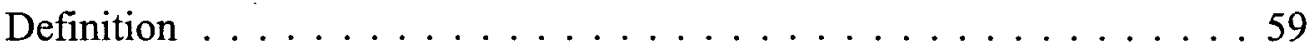

Historical Overview of Culture and Religion $\ldots \ldots \ldots \ldots 63$

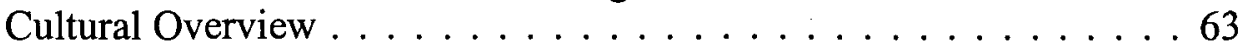

Religious Overview . . . . . . . . . . . . . . . 65

Factors Influencing Cultural and Religious Changes . . . . . . . 67

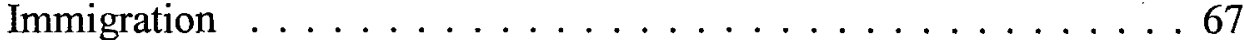

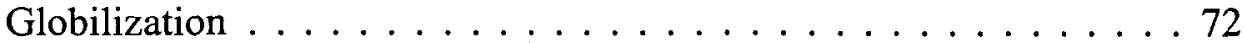

Religions . . . . . . . . . . . . . . . . . . . . . 75

Declining Influence of the Church of England $\ldots \ldots \ldots 77$

Impact of Pluralism . . . . . . . . . . . . . . . . . 88

Impact of Islam $\ldots \ldots \ldots \ldots$

Postmodernism .....................88

Cultural Implications . . . . . . . . . . . . . . . . . . . . 899

Religious Implications . . . . . . . . . . . . . . . . . . 91

Effects of Cultural/Social Changes on the Seventh-day

Adventist Church . . . . . . . . . . . . . . . . . . 95

Role of Women. . . . . . . . . . . . . . . . . . . . . .996

Increase in Lay Decision Makers . . . . . . . . . . . . . . . 97

Willingness to Break from Tradition . . . . . . . . . . . . . . 97

Seventh-day Adventist Response . . . . . . . . . . . . . . . 102

IV. THEOLOGICAL FOUNDATION FOR LAY INVOLVEMENT $\ldots \ldots \ldots$

Call for Lay Involvement . . . . . . . . . . . . . . . . . . 107

Ministry of Women. . . . . . . . . . . . . . . . . . . . . . . . 112

Need for Spiritual Mentors . . . . . . . . . . . . . . . . . . 114

Motivating People for Ministry . . . . . . . . . . . . . . 120

Impact of Involvement . . . . . . . . . . . . . . . 126

V. STRATEGY FOR THE MOTIVATION OF THE UNINVOLVED

CHURCH MEMBER . . . . . . . . . . . . . . . . . . . . . . . . . . 128

Profile of the Gloucester SDA Church . . . . . . . . . . . . . 128

A Brief History . . . . . . . . . . . . . . . . . . 128

The Membership . . . . . . . . . . . . . . . . . . . 130

The Worship Style . . . . . . . . . . . . . . . . . 133

Development of the Strategy for Involvement . . . . . . . . . . . . 134

Description of Strategy . . . . . . . . . . . . . . . . . . . . 137

Resources for Increased Knowledge . . . . . . . . . . . . . . 138

Performance Objectives . . . . . . . . . . . . . . . . . . 143

Resources for Change of Attitude . . . . . . . . . . . . . . . . 144 
Performance Objectives . . . . . . . . . . . . . . . . . . . . . 144

Development of Skills . . . . . . . . . . . . . . . . . . . . . 145

Mobilizing Members for Ministry . . . . . . . . . . . . . . . . 146

Implementation Strategy . . . . . . . . . . . . . . . . . 146

Impact of Lay Involvement . . . . . . . . . . . . . 150

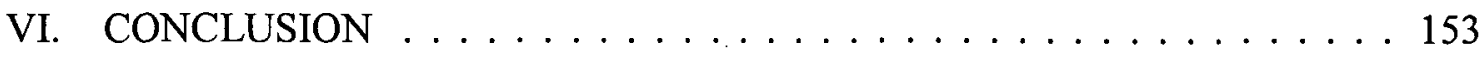

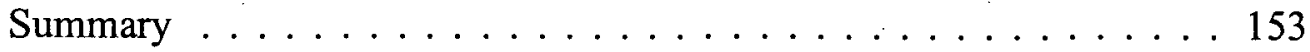

Lessons Learned . . . . . . . . . . . . . . . . . . . . . . 154

Recommendations ................... 156

Appendix

A. Church Involvement Survey Results . . . . . . . . . . . . . . 159

B. Logical Framework for Motivating Uninvolved Members

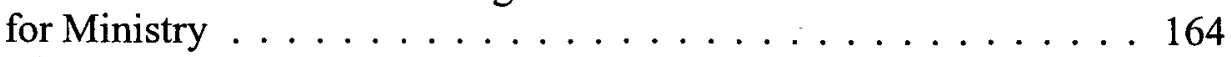

C. Activities Schedule . . . . . . . . . . . . . . . . . 166

D. A Personal Core Values Audit . . . . . . . . . . . . . . . . . 167

E. Outline for Seminar on Behavioral Styles . . . . . . . . . . . . . 169

F. Outline for Seminar in Spiritual Gifts . . . . . . . . . . . . 171

G. Outline for Seminar in Change of Attitude . . . . . . . . . 172

H. Spiritual Gifts Inventory for Individuals and Congregations . . . . . . 174

I. Spiritual Gifts Inventory Score Sheet . . . . . . . . . . . . 180

J. Evaluation Sheets . . . . . . . . . . . . . . . . . . . 181

BIBLIOGRAPHY $\ldots \ldots \ldots \ldots \ldots \ldots \ldots \ldots \ldots \ldots \ldots \ldots \ldots \ldots$

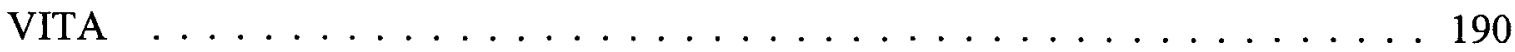




\section{LIST OF FIGURES}

1. Membership of Non-Christian Religions in UK . . . . . . . . . . . . . . 94

2. B.U.C. Executive Committee, $1950-2001 \ldots \ldots \ldots$. . . . . . . 98

3. B.U.C. Executive Committee Membership Percentages, 1976 . . . . . . . . 99

4. B.U.C. Executive Committee Membership Percentages, 2001 . . . . . . . . 99

5. Gloucester Church Gains $\ldots \ldots \ldots \ldots \ldots \ldots \ldots$

6. Gloucester Transfers $\ldots \ldots \ldots \ldots \ldots \ldots \ldots \ldots \ldots \ldots$

7. Gloucester Losses $\ldots \ldots \ldots \ldots$. . . . . . . . . . . . . . . . . . . .

8. Reading a Logframe . . . . . . . . . . . . . . . . . . 135

9. Response Slip . . . . . . . . . . . . . . . . . . . . 148

\section{LIST OF TABLES}

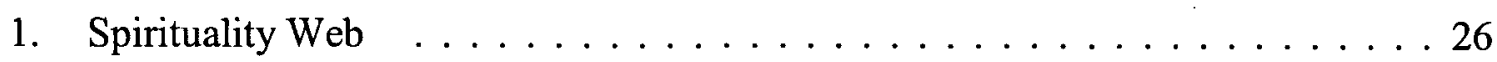

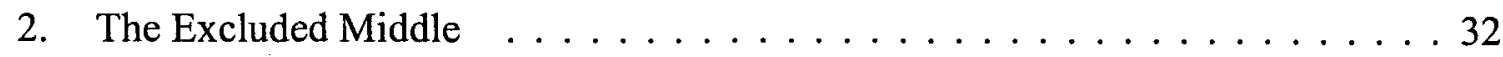

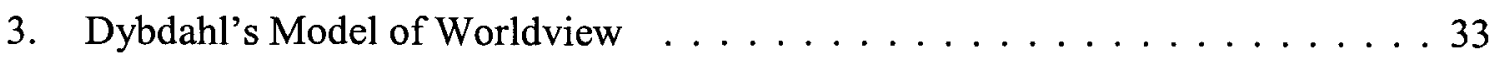

4. Components of Bible Study $\ldots \ldots \ldots \ldots \ldots \ldots \ldots$

5. Residence of Minority Ethnic Population by English Regions,

Wales, and Scotland . . . . . . . . . . . . . . . . . 69

6. Anglican Opinion on Ordination . . . . . . . . . . . . . . 79 


\section{LIST OF ABBREVIATIONS}

B.U.C. British Union Conference

D.Min. Doctor of Ministry

E-I Extraversion-Introversion

ISTJ Introverted--Sensing-Thinking—Judging

J-P Judging-Perceiving

LXX Septuagint

MBTI Myers-Briggs Type Indicator

S.E.C. South England Conference

S-N Sensing-iNtuition

TDNT Theological Dictionary of the New Testament

T-F Thinking-Feeling 


\section{ACKNOWLEDGMENTS}

I gratefully acknowledge the contributions of the following persons and bodies for the completion of this dissertation.

First of all I acknowledge and thank God for the mind and the privilege to be able to undertake a course such as this. This ability is not something that I would want to take for granted.

I acknowledge and express grateful thanks to the Trans-European Division, the British Union Conference, and the South England Conference for the three-way scholarship provided for me to undertake this study. Without your help this would not have been possible at this time.

I acknowledge and thank my lecturers and supervisors from Andrews University, Dr. Bruce Bauer, and Dr. Rudi Maier for their untiring attention given throughout the course. I appreciate the contributions also of Dr. Jon Dybdahl who set the pace for the D.Min. by leading me through spiritual formation and introducing many concepts which will stay with me throughout my life and ministry. I thank Dr. Gordon Doss who contributed to my understanding of culture and missions.

Recognition is also given to staff and management of Newbold College in Bracknell, Berkshire, England for hosting this course on behalf of Andrews University. I have especially appreciated the quality of food served in the cafeteria.

I am grateful for the opportunity afforded me to meet and spend four summers with such a spiritual and friendly cohort from across the TED and beyond. Their 
contributions have helped me to shape my final product, and I will be eternally grateful. I have made some new friends, and as colleagues I hope there will be opportunity to work together some time in the future on a special mission project.

Finally, I am eternally grateful to my wife Rhona who has encouraged me from the word "go." She has sacrificed much in having to travel by public transport just to allow me the time away. My love for her grows each day. My two teenage sons Christopher and Jason have been great. Without their understanding and encouragement the completion of the Doctor of Ministry program would have been more difficult. 


\section{CHAPTER I}

\section{INTRODUCTION}

\section{Problem}

In the average Seventh-day Adventist church in the South England Conference the pastor is often not equipped with the time and the resources to conduct an adequate training and education program for the uninvolved member. Spiritual Gifts seminars, outreach, and witnessing seminars are often conducted away from the local church and are largely supported only by those who are already deeply committed, but the shy, introverted, and uninformed member is increasingly uninvolved in the work of soul winning and the local ministries, and is not involved in the training activities of the church. In the year 1896, Ellen G. White stated that when the majority of the church is active in soul winning the Holy Spirit will be poured out. "The great outpouring of the Spirit of God, which lightens the whole earth with His glory, will not come until we have an enlightened people that know by experience what it means to be laborers together with God. When we have entire, wholehearted consecration to the service of Christ, God will recognize the fact by an outpouring of His Spirit without measure; but this will not be while the largest portion of the church are not laborers together with God."1

${ }^{1}$ Ellen G. White, Instruction for Effective Christian Service (Hagerstown, MD: Review and Herald Publishing Association, 1896), 253. 
If this statement is correct then there needs to be an increased amount of involvement in the work of God and it must begin in the local church. The purpose of this project is to highlight the need among local church members for more active involvement and to suggest and implement a strategy for reintegration of the uninvolved member into greater involvement in the main program and mission of the local church. It also offers a strategy that will give the local church pastor a systematic approach to evaluative training and equipping of the local uninvolved lay member. The aim is to further implement this strategy on a wider basis in the local churches throughout the South England Conference.

\section{Justification}

The justification for this project is found not only in the statement by Ellen G. White, already quoted above, but also in the writer's personal experience in ministry and in the results of surveys conducted in three churches in the South England Conference; the results of which are shown in appendix A. The results show not only that there is a need for greater involvement of church members in ministry, it also illustrates that the uninvolved members have a desire to become more involved in their local church ministries. Even those who are involved in ministry state that they are not involved in the areas of their giftedness. Greater involvement will generate a greater sense of well being amongst the general church membership in that they will feel more fulfilled in knowing that they are contributing to the over-all growth of the church. 
According to records of the Gloucester Seventh-day Adventist Church, ${ }^{1}$ of a membership of one hundred and fifty-three, only fifty members have been nominated to an office in the church. Even though this, in itself, does not indicate uninvolvement, it does indicate that some members are carrying two or three offices while two-thirds of the membership is not carrying any responsibility. The survey results of the Gloucester Church show that of those who responded to the survey, the majority spend less than one hour per week in ministry. More than half the respondents who had gone for training in ministry stated that they went for training in order to be better equipped for ministry. This indicates that members generally want to be involved in their local church ministries, if only they knew how. When asked their reason for not being involved the majority said either (1) they lacked motivation to be involved, or (2) there were no opportunities for ministry in their local church. However, when asked about their attitude toward involvement in the local church, none said that they did not want to be involved, and the majority of those who were already involved said that they were enjoying it.

When the majority of the members are involved in ministry there is less demand on the individual member's time and energy. There is less stress, and a greater sense of accomplishment is experienced by the church on a whole.

\section{Definitions}

Uninvolvement can have a wide variety of meanings, depending on one's purpose and context. In relation to church membership, uninvolvement may suggest that the member is no longer functioning as a supporter of the local church while still retaining 2004.

\footnotetext{
'Data taken from "Gloucester SDA Church Nominating Committee Report,"
} 
their name on the church books. John S. Savage expresses interest in the church member who was once deeply involved at the center of the church's life and within two years shows disinterest. ${ }^{1}$ This disinterest ranges from sitting in the pew as an observer to actually being absent from the church community due to some unresolved bitterness or disgruntlement.

For the purposes of this paper, uninvolvement is defined as having membership in a local church, maintaining a regular presence in the worship experience of the church, but not engaging in any meaningful witness or ministry run by or supported by the local church that offers any lasting satisfaction and sense of fulfillment. There may not necessarily be a harboring of any overt bitterness or resentment toward anybody in particular, which may prevent one from being involved; the fact of the matter is that while some members are involved others may be enjoying their involvement, but are themselves nothing more than observers.

Other terms used within this paper include:

The British Union Conference of Seventh-day Adventists (BUC) located in Watford, Hertfordshire, England, is the managing body of the work of the Seventh-day Adventist Church throughout the British Isles.

The South England Conference of Seventh-day Adventists (SEC) located in Watford, Hertfordshire, England, is the managing body of the work of the Seventh-day Adventist Church in the south of England.

${ }^{1}$ John S. Savage, The Apathetic and Bored Church Member: Psychological and Theological Implications (Reynoldsburg, OH: LEAD Consultants, Inc., 1976), 1. 


\section{Limitations}

The implementation of this project has been restricted by certain limitations. First, this project is not intended to give a detailed explanation of Spiritual Gifts neither is it intended to expound on the different theories on personality types that can be found in literature. The use of these tools in the implementation of this project is purely to introduce the subjects and highlight their importance in engaging in meaningful ministry.

Second, the literature review found within the paper is not intended to give an exhaustive account of the subjects discussed. It is intended merely to outline the cultural and religious context, in which this project is implemented. The reader is urged to do independent study on any area of interest that might be stimulated by the discussions that will ensue.

Third, the project was proposed when I was pastor of a local church in London. This meant that the intended pilot audience was my then local congregation. However, after two years into the project I was asked to serve in the administrative offices of the South England Conference as Ministerial Secretary. This moved me out of the local church. In order to implement the project it became necessary to conduct it in a church over which I had no direct pastoral influence. This had implications on financing the project, control over the timing of the project, personal knowledge of the membership, and also the available resources.

Finally, the implementation of this project may "unearth" other issues and problems relating to the local church and its ministries; however the purpose of this project is not to attempt to fix or address these problems, even though suggestions and 
recommendations may be made to the church in order to facilitate the implementation of this project.

\section{Methodology}

In order to conduct this project it was necessary to first construct a questionnaire in order to gain information that would support the perceived need for such a project. This questionnaire was drafted and distributed among church members and colleagues generally in order to test the questionnaire. Comments on style and content were made and adjustments to the format and questions were implemented. The questionnaire was then finalized and distributed to the members of three churches in the South England Conference. These churches were not pre-selected in any way; they just happened to coincide with my itinerant preaching plan for that time. The questionnaires were completed by the majority of the members in attendance on the same Sabbaths that they

were distributed. The three churches were Gloucester Church, in Gloucestershire, Fulham Church in west London, and Tottenham West Green Road Church, in north London.

After selecting one of the three churches in which to conduct the project it then became necessary to approach the pastor of the church concerning the possibility of using his church as a pilot for the project. After an initial consent it was arranged for me to address the church board who then unanimously gave their consent for the project to be conducted in their church.

The next step was to prepare and conduct a series of seminars intended to (1) increase the knowledge of the members concerning their spiritual gifts and its relationship to ministry, (2) show the members the importance of personality type and its relationship to ministry, and (3) show the members how to change their attitude toward 
ministry by understanding the concept of values, and how a comparison of God's values and their values could encourage a change of attitude. Included in these series of seminars is training for the mentors in how to work with, encourage, and support the uninvolved. These series of seminars are then followed by the mobilization of the uninvolved members into ministry that is in line with their gifts and personality type. The mentors, whose job it is to encourage and morally support these members are, themselves, encouraged and supported by the project manager.

This paper is structured into six main chapters. Chapter 1 introduces the project, outlining its main purpose, justification, and limitations. Chapter 2 explores my spiritual, personal, and theological foundation for ministry, paying close attention to the factors that have influenced both my call to ministry and my particular style of ministry, from my early years to my present ministry situation.

Chapter 3 investigates the cultural context in which this project is conducted. It discusses the religious and cultural environment that the Seventh-day Adventist Church in Britain is called to minister in and how these factors have influenced change on the part of the church. Chapter 4 discusses the theological foundation for lay involvement. Here is outlined the biblical mandate for lay ministry and why this project is necessary for increased church growth. Chapter 5 outlines the strategy that was followed in implementing the project, and the final chapter is the conclusion and recommendation to the pilot church. 


\section{CHAPTER II}

\section{PERSONAL SPIRITUAL AND THEOLOGICAL FOUNDATION FOR MINISTRY}

\section{Personal Profile}

Writing about my own spiritual, personal, and theological foundation for ministry does not come naturally. My personality type suggests that I am a private and reserved person who prefers to listen to others talk about themselves than to spend time talking about myself. I have learned, however, that as unnatural as it may appear to be, it is, nevertheless, an important step in understanding one's own calling to a work that involves so much of the person. This extends to understanding my reasons for ministering the way I do.

Understanding one's own calling requires analysis and a deeper exploration of one's self than one is normally called to undergo. Accepting the call to ministry and then just getting on with it without taking time for a spiritual, personal, and theological searching of self can be quite limiting. But, on the other hand, the results of such an exercise will prove, at times, to be quite revealing and, at times, a confirmation of what was already known or perceived.

This chapter sets out to accomplish just that. In it I will explore briefly my early years and the influences that shaped both my character development and my calling to 
ministry. It is one that explores my personality and how it impacts on my spirituality and my theological interpretation. It also explores my theological definition of ministry and how it relates to the church with which I both live and work. An understanding of one's calling must also include an understanding of the job one is called to do. In the final two sections it will be perceived that my personality type influences even this. It will be seen that my theological basis for ministry is determined by my theological understanding for ministry.

\section{Biography}

I am a product of the British Empire. I am a "baby boomer" who was born at a time when, in the 1950s, the aftermath of the Second World War left high unemployment in the British colonies of the West Indies. To add "hurt to injury," in Jamaica, hurricane damage had destroyed crop and crippled the economy. ${ }^{1}$ It was a time when young men and women left their islands and went to the United States of America in search of casual labor but because of restrictive US immigration laws many were forced to turn to Britain, the "mother country."

After the arrival of "The Empire Windrush" in 1948 a steady stream of immigrants began to flow into Britain but in 1956, the year before my birth, due to a severe labor shortage in Britain, the London Transport and the newly formed National Health Service began an active recruitment drive in the Caribbean for transport workers

\footnotetext{
'Peter Fryer, Staying Power: The History of Black People in Britain (London: Pluto Press, 1984), 373.

${ }^{2}$ Tony Sewell, Keep on Moving. The Windrush Legacy (London: Voice Enterprise Ltd., 1998), 7.
} 
and hospital staff: both experienced and trainees. ${ }^{1}$ They came to "better" themselves. The plan was to come for only a short time, maybe five years or so, and then to return home to the Caribbean to rebuild their lives. Little did they know that the five years would stretch to fifty years and more.

It was a time of transition for many young Jamaicans and it was in this climate that I was born, in the winter of 1957. Soon after my birth, my parents, like so many others, left the shores of their beautiful island and set sail for England. Being unsure of what to expect, and, what was a common act in those days, they thought it wise not to take their children with them until they were settled and had earned enough to pay the children's passage. So while my parents worked in England and made preparations for our arrival aunts and uncles cared for my younger brother and me.

My early years in Jamaica away from my parents, I remember, were times of searching for my own identity. As with all young boys of about four or five years of age, my identity was found in my parents. My other cousins were referring to mama and papa, but I referred to aunty and uncle. I knew I had a mama and papa somewhere, but what they looked like was just a vague memory. I seem to recollect that there were plans for me to go to England some day, but the excitement of travel that is inherent in most young boys, for some reason, was not there for me-at least I do not remember it. My community was all I knew. My extended family around me and the street, woodland, and rivers in which I played as a little boy was my world and I knew and desired nothing else.

Nevertheless, the day finally arrived when I landed in England. Two men met us at Heathrow airport. One of them was my father, but as to which one, I was at a loss. I

${ }^{1}$ Ibid., 38. 
remember sitting in the back of the car on the way from the airport and silently taking my pick as to which one I wanted to be my father. It so happened that the one that I chose turned out to be the right choice.

Growing up in England from a very early age was a challenge in many respects. A young boy coming from the tropics first of all had to quickly adapt himself to the cold climate of Britain. Nobody warned that the weather would drastically change overnight. Secondly, I had to come to the realization that the funny accent was mine, and not theirs. As a child, getting used to these differences was not a difficult thing because children of my age were able to learn and adapt quite easily. However, as I grew and the years passed I began to pick up the warnings from the adults in my community to be aware of color prejudice. How does a young boy protect himself from color prejudice? It is a concept that I found hard to come to terms with. At that age I did not think in color. These things are learned through the experiences and the "hard knocks" of life. Only as an adult did I pause to reflect on life and realized that through the innocence of childhood I was blindfolded from many racist episodes.

My greatest challenges came during my secondary school years when children begin to learn what differences are and what racial prejudice is. My parents, mother in particular, made numerous trips to my school to defend her son because of racist teachers and fights in the playground. As a young teenager I remember having to physically defend my ground and my right to be considered as equal, which was not understood by my fellow Caucasian English pupils, or by some of my Caucasian English teachers.

Perhaps my greatest disappointment in my latter teenage years was coming to the realization that not only was there racial prejudice in my school, but there was also racial 
prejudice in the church that I had grown to love and that had played such a major role in my life.

I was baptized in the year 1973, at the age of fourteen years. At that time I was not aware of the racial conflicts in the church and it was not until I had reached the age of approximately eighteen when it finally hit me. It had been talked about but it was something that the adults were dealing with, and now it became an issue that I too was confronted with. The realization came at a time after I had spent many years getting to know a different culture and adapting my behavior accordingly. My accent was no longer funny. I had gotten used to the cold weather, and I was eating English food. This awakening came at a time when I was beginning to compete with my peers in the job market place. It came at a time when I began to hear, what I believed to be the call to become a preacher of the Gospel. If I accepted the call my remit would be to work for a people whose grandparents did not trust me and whose parents did not really get to know me, even though we schooled together, fought in the same playground, and competed for the same jobs.

My earliest awareness of spirituality came in my junior years. It could not have been a sudden awakening but a gradual awareness because I cannot really recall any one moment during these years that I felt more elated, spiritually, than at other times. I do remember at about the age of four or five years that I was in the presence of two of my uncles in Jamaica, and heard them debating, or at least posing the question, as to the origin of God. "If God made man, then who made God?" I do not remember an answer being given or any follow-up to the discussion. 
My introduction to church as a regular life discipline came around the age of eight years when my mother was baptized at Lewisham Seventh-day Adventist Church in South London, England. It was from this point that we began to attend church regularly, and I began to identify with a spiritual community. These early years in church proved to be invaluable. These were fun years. Growing up in the church with other children of my peer group gave me identity. Even though as children we played around when we should have been listening to the presentations, coming to church because my friends were there was a catalyst in my spiritual formation. At that age Sabbath was looked forward to because I associated Sabbath with seeing friends who understood why I went to church. School friends were fine-for school, but church friends were the ones I looked forward to seeing most, even though it was for only one day of the week.

The Bible stories that I learned from the Sabbath School lessons began to instill in me an understanding of who God was. I developed a deep respect for the person of God, so much so that I found it extremely difficult to utter profanity, and even to utter the words, "I hate God." I challenged myself to think those words in my mind, but I could not. The songs that we sang as children created a joy for worship and a bonding among my peers. These were the things that created identity among us. In my early teenage years many social functions helped to satisfy the basic needs of a young teenage Christian. Church was not just a place for preaching, singing, and praying; it was a place also to let one's hair down with people who were of like mind.

My mid to late teenage years were perhaps the most serious years of my spiritual journey. Serious, in that it was during these years that I became very conscious of the fact that I wanted to be a good Christian. I had been baptized at the age of fourteen and 
had begun a steady growth in spirituality. My commitment to the work of the church grew. I had a deep-seated desire to see church programs run well. I almost felt responsible when things did not run smoothly. During these years there came a time when I was the only member of my family who was attending church regularly. A period of religious isolation threatened, but thank God it did not last for too long.

My work and responsibilities in my local church played a significant role in awakening in me the desire to preach the gospel and train for the pastoral ministry. This growing conviction became more marked in my early adult years when I finally responded to, what I believed was, a call from God. Even though I was enjoying working as a bookkeeper and studying accounting in the evenings it became increasingly clear to me that there was something else that God wanted me to do. After fasting and praying on the subject for approximately four Sabbaths I decided to apply to Newbold College for acceptance to the ministerial training course. My application was not accepted. Being greatly disappointed and confused I resigned myself to the fact that what I had perceived to be a call from God was in fact a hoax. Maybe accounting was my calling.

As things turned out, God was showing me that my planned route to ministry was not his planned route for me. Totally unsolicited and unbeknown to me an application form for Oakwood College in Huntsville, Alabama arrived at my home. I had never previously heard of Oakwood College. The application was submitted and I was accepted. While at Oakwood College I received confirmation, after a day of prayer and fasting, that God had called me to the Gospel ministry. Five of the most meaningful and spiritually rewarding years of my life were spent on this college campus. Seven years 
later after completing post-graduate work at Newbold College I entered the Gospel ministry.

In his book on how God shapes spiritual leaders, Reggie McNeal discusses the subject of, what he calls, "The Commonplace." In it he states, "The common place is the stuff of routine life. The moments when no one is looking. The commonplace experiences fill the backdrop to the leader's life drama. They are like the unstaged, spontaneous photographs that complement the staged pictures in the wedding photo album. Over time, the candid shots often prove to be more intriguing. They capture life in the making." 1

Even though the commonplace may capture life in the making it is evident that the commonplace is more appreciated in retrospect. This is an adult thing. Just as children do not appreciate discipline at the time, so likewise, we do not appreciate the commonplace during childhood years. The interpretation of life is a privilege that can only be cherished during mature years, after experience has been gained. However, having said that, it is also evident that even during mature years the interpretation of the commonplace is possible only upon reflection on the past.

As I reflect on my past I can appreciate how God has shaped me through my commonplace. At the time I could not see the future and did not know what the future held. Life was lived one day at a time and the shaping of my life by the commonplace was totally unperceived. If I were to go back and erase any part of my life my spiritual formation would have been greatly affected. Fortunately, with our common place, we are

\footnotetext{
${ }^{1}$ Reggie McNeal, $A$ Work of Heart: Understanding How God Shapes Spiritual Leaders (San Francisco, CA: Jossey-Bass Publishers, 2000), 177.
} 
not free to manipulate it, as we see fit. I agree with McNeal in saying that it is God who uses the common place to shape the heart of the leader. ${ }^{1}$ God, who knew what I needed most as a spiritual being, used my every day experiences to build me into what I am today. McNeal refers to this as "the sacredness of the ordinary."

\section{Present Ministry Situation}

On entering the ministry in 1987 , I was assigned to work as an intern minister in the Holloway and Kings Cross churches in north London. After serving for two and a half years I then moved on to pastor another seven churches over the next twelve and a half years. These years led me to the counties of Hertfordshire, Bedfordshire, and Buckinghamshire, and then finally back to north London. Throughout this time I had the privilege of pastoring a variety of peoples from different parts of the world, from Tonga to Latvia, and from England to Africa and the Americas. Working with such a vast variety of peoples has given me a broader worldview and a greater appreciation and tolerance for people and their differences.

After starting the ministry I soon learned that there are certain factors that influence one's goals, plans, and aspirations for ministry. One thing that I learned fairly quickly was that there must be life outside the church. As a young bachelor and a graduate, my energy levels were high and so were my aspirations. The Lord was coming tomorrow and it was my job to make it happen. I was busy running here and there until my supervisor had to advise me to slow down and take some time for myself. I had not

\footnotetext{
${ }^{1}$ Ibid.

${ }^{2}$ Tbid., 178.
} 
yet heard of burnout. Life outside the church included time to visit my parents, time for holidays, and time to court my girlfriend, Rhona, whom I had proposed to the day I started ministry.

Rhona and I were married in May of 1988. This event began another learning curve because I learned that marriage and home is another major influence in one's ministry, and a positive one, I might add. Marriage and home gave a new dimension to my ministry and when the children arrived sixteen months and three years later a deeper sense of responsibility and obligation was added. I had to learn and accept that time spent with my wife and children was not robbing me of ministry time, but was enhancing my ministry. Guilt, due to misunderstanding of the call, can be a destroyer of effectiveness. Life outside the church helped to teach me the depth of true ministry. Marriage, home, and children helped to expose me to myself, which has influenced my present ministry situation.

Eighteen years of ministry prepared me to have pastored two of the larger churches in the London district with the challenges of the need for change in administrative thinking, evangelistic apathy, and balance between postmodernism and traditionalism. In the four years as pastor of the Tottenham West Green Road Church in north London I had felt the need to mobilize the membership for more personal involvement in ministry. Training has been given to local Bible workers to equip them for greater and more effective service. Senior elders have been given special counseling training to help them be more effective with the members of the church. Other departmental personnel have had training in their respective fields to prepare them for greater efficiency in ministry. 
In the relatively short spell of twelve months spent pastoring the Chiswick Church in the west London area, I found that I was embarked on similar tasks as that of Tottenham West Green Road. Presently, as Ministerial Association Director for the South England Conference, it is evident that my eighteen years of ministry and the benefits of this Doctor of Ministry course have ignited a passion for new challenges and a drive to implement new ministry ideas. My deeper understanding of worldview will help me to structure my ministry to the needs of the people and help congregations and colleagues in ministry to understand the needs of others and to exercise greater tolerance toward differences.

Serving as Ministerial Director for the conference has taken me out of the local church situation on a consistent basis. As a local church pastor I enjoyed the relationship which I had with the members and the opportunity to develop programs that were geared toward personal development in the areas of spirituality and mission. As the "pastor's pastor" I find that this has become one of the most challenging and yet rewarding parts of my job. Developing and structuring professional development programs for pastors seem to be what many of the pastors in the South England Conference are wanting as a primary need. To feel qualified and competent to do the job that one is assigned to do is perhaps one of the most motivating factors for excellence. As with the pastor, so it is with the church member.

The change from being a local church pastor to being a conference departmental director has not robbed me of my passion for developing people. Whenever I visit a church and perceive problems among the membership, there is a drive within me to want to "fix it." Self discipline reminds me that this particular problem is no longer mine to 
fix. The challenge for a ministerial secretary in my position is now to channel that energy to my colleagues in ministry, and mature to the point of being able to acknowledge that the solution to many problems lies in the hands of my colleagues, the pastors.

\section{Personality}

\section{Temperament}

There appears to be differing thoughts as to whether there should be a distinction between "personality" and "temperament." Tim LaHaye suggests that there is a distinction. He states, "Temperament is the combination of inborn traits that subconsciously affect man's behavior," and are passed on genetically and determined by "nationality, race, sex and other hereditary factors."' On the other hand he perceives personality as something that is outward and is a portrayal of the real self. This real self he describes as character, our "civilized" temperament. ${ }^{2}$

Somehow I am of the opinion that both "temperament" and "personality" are one and the same and can be used interchangeably, whereas, character is the outward portrayal of the real self. This is affected by childhood upbringing, education, environment, and our commonplace. The temperament determines the activity of God in our lives that he uses to shape us. God considers each of us individually, and works with

${ }^{1}$ Tim LaHaye, Spirit-Controlled Temperament (Wheaton, IL: Tyndale House Publishers, 1966), 5, 6 .

${ }^{2}$ Ibid., 6. 
us as our needs dictate. Because our temperaments are as varied as our faces, so are God's dealings with each of his children.

The mother and daughter team, Katherine Cook Briggs (1875-1968) and Isabel Briggs Myers (1897-1980), spent many years studying the ideas of the Swiss psychiatrist Carl G. Jung (1875-1961) who developed a theory of the differences in temperament of healthy people. ${ }^{1}$ They wanted to understand every-day people around them and so developed a temperament type indicator known as the MBTI. It describes sixteen temperament types with which each person is able to identify his or her type. The test in no way claims infallibility but is generally understood and accepted to be the most scientific indicator available today.

The MBTI identifies four preferences that indicate the way people process information received from the world around them. These preferences are grouped in four pairs of letters, namely, E-I, S-N, T-F and J-P.

The E-I preference describes one's focus for getting energy. It is either EExtraversion, or I-Introversion. The S-N preference describes how one prefers to take in information: either by S-Sensing, or by $\mathrm{N}$-iNtuition. The T-F preference describes one's decision-making process: either by T-Thinking, or by F-Feeling. And finally, the J-P preference describes the way we deal with the outside world: either by J-Judging, or by P-Perceiving.

\footnotetext{
${ }^{1}$ Isabel Briggs Myers, Introduction to Type: A Guide to Understanding Your Results on the Myers-Briggs Type Indicator (Oxford, UK: Information Press, 2000), 5.
} 
My temperament type, according to the MBTI, is ISTJ. This means that I am first of all an "I." My energy is gained mostly by Introversion. My inner world, ideas, and experiences are all important to me, and that is where I prefer to focus. I am thought oriented and love to reflect on memories and feelings. ${ }^{1}$

The " $S$ " in my temperament type preference means "Sensing." People who prefer Sensing like to take in information that is real and tangible--what actually is happening. They are observant about the details of what is going on around them and are especially attuned to practical realities.

\section{Characteristics associated with people who prefer Sensing:}

Oriented to present realities

Factual and concrete

Focus on what is real and actual

Observe and remember details

Build carefully and thoroughly towards conclusions

Understand ideas and theories through practical applications

Trust experience. ${ }^{2}$

My third type preference is " $T$ " for Thinking, describing my decision-making process. In describing these characteristics Isabel Briggs Myers states, "People who prefer to use Thinking in decision making like to look at the logical consequences of a choice or action. They want to remove themselves mentally from the situation to examine the pros and cons objectively. They are energised by evaluating and analysing

\footnotetext{
${ }^{1}$ Ibid., 9.

${ }^{2}$ Ibid.
} 
to identify what's wrong with something so they can solve the problem. Their goal is to find a standard or principle that will apply in all similar situations."”

The "J" (Judging) in my type preference suggests that I like organization and structure, and try to avoid last minute stresses. Myers further suggests, "People who prefer to use their judging process in the outer world like to live in a planned, orderly way, seeking to regulate and manage their lives. They want to make decisions, come to closure, and move on. Their lives tend to be structured and organized, and they like to have things settled. Sticking to a plan and schedule is very important to them, and they are energised by getting things done."2

The above descriptions of an ISTJ seem to fit me quite well for most of the time; however, there are times when I do not completely fit into those categories. My IST seems to be fairly consistent but the $\mathrm{J}$ part of me does not seem to come through all the time. There are times when I do identify the $\mathrm{P}$ in my temperament. There are times when I am somewhat casual and flexible in my approach to certain aspects of life. Closure is often perceived to be pre-mature and I feel happier when things are left open, to go with the flow. Mulholland appears to suggest that this is quite normal. Mature individuals are able to adapt to differing situations as demand arises, and so our dominant

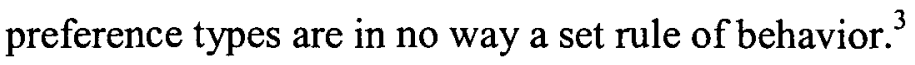

${ }^{1}$ Ibid., 10.

${ }^{2}$ Ibid.

${ }^{3}$ M. Robert Mulholland, Jr., Invitation to a Journey: A Road Map for Spiritual Formation (Downers Grove, IL: InterVarsity Press, 1993), 54. 


\section{Spiritual Gifts}

My understanding of spiritual gifts has for some time now been in conflict with the conventional teaching and understanding of what gifts are. From my understanding of conventional teaching, spiritual gifts are really the use of our God-given talents in the church environment. There are personnel working in the secular industries who seem to portray the same skills in management, oration, singing, compassion, and many other areas that the church has identified as spiritual gifts. If what the church identifies as spiritual gifts are indeed spiritual gifts, then spiritual gifts are not limited to the church. It appears to me that we need to clarify what we mean by the term spiritual gifts.

It is interesting to note that the apostle Paul alone addresses the subject of spiritual gifts in relation to the work of the church. Other New Testament writers address the power of the Holy Spirit when it comes to fulfilling the Gospel commission (see Matt 10:19, 20; Mark 16:15, 16; Luke 24:49; Acts 1:4,8). What did Paul mean by the term "spiritual gifts"? And why did he find it necessary to address the subject? Unfortunately, this discussion will have to remain for another time and forum.

It is my present understanding that talents and natural abilities are taken by God and empowered by his Spirit for the purpose of influencing people with the knowledge of Jesus Christ, leading them to salvation, and finally nurturing them in the body of Christ, the church. This means that everyone should be aware of what he or she is good at and enjoys doing. Some may not be able to label talents in relation to the conventional term, spiritual gifts, and possibly have difficulty seeing where they fit, and how they can be used in the overall program of a local church. For those who have this difficulty, it may be necessary to conduct a "spiritual gifts inventory" to help them to see their talents and 
abilities in light of the work of the church. Once each born again Christian realizes that the call by God to minister then they are endowed with the power of the Holy Spirit. The promise from Christ is not that the church will receive gifts, but that we will receive power after the Holy Spirit has come upon us, and we shall be witnesses (Acts 1:8). The effectiveness of our witness is determined by the presence and the power of the Holy Spirit. As people dedicate their natural talents and abilities in service God uses them, whether they are ten, five, or one to influence lives for salvation.

According to Dick and Miller's Spiritual Gift Inventory, ${ }^{1}$ my spiritual gifts are strongest in Prophecy, Teaching, Shepherding/Faith, and Evangelism. This did not surprise me because I have, for a long time, felt that my calling has been to preach and teach. I believe that these are what I do best and enjoy doing the most. Before I took the inventory many had confirmed that they felt these were my strengths, so therefore, the test was just a confirmation of what I had already suspected.

\section{Leadership/Interaction Style}

I am appreciative of Dick and Miller for introducing the Leadership/Interaction Styles that have helped me to identify why I lead and interact the way I do. In their definition they state that, "While the Spiritual Gifts Inventory names the spiritual dimension of our relationships, the Leadership/Interaction Styles tool points to the ways we behave with one another. It is in our interactions that our gifts are seen, known, and cherished - or blocked and ignored. The Leadership/Interaction Styles tool helps to

${ }^{\mathrm{I}}$ Dan R. Dick and Barbara Miller, Equipped for Every Good Work: Building a Gift-Based Church (Nashville, TN: Discipleship Resources, 2001), 31-36. 
reveal why we work as we do and to further our ability to truly know and appreciate one another as multi-dimensional and valuable."

Four Leadership/Interaction Styles are suggested. Two are predominantly taskoriented, and two are people-oriented. The task-oriented styles are: (1) Thinkers, who have a deep sense of mission for getting the job done no matter what it takes, and (2) Directors, who are more focused on the results than the process. The people-oriented styles are: (1) Dreamers, who are more concerned with the social dimension and having a fun time in the process, and (2) Pleasers, who like a balanced approach to whatever the task and ensure that everyone has a fair say.

My dominant style is a Thinker, even though I have identified some of all styles manifesting themselves at times. Among other things, Thinkers are described as being highly organized, and prefer facts, information, and data to make decisions. They can appear to be somewhat pedantic when it comes to detail and delay when it comes to making a decision and giving their opinion.

Because of the internal engagement of Thinkers they run the risk of being accused of being cold and withdrawn. However, it is when Thinkers are allowed their periods of silence that their creative planning comes into play.

\section{Spirituality Web}

The Spirituality Web has nothing to do with spiders in church but has all to do with the way we experience and approach God. Dick and Miller give further clarification by stating that, "Approach ... refers to the way we transmit to God; Experience refers to

\footnotetext{
${ }^{1}$ Ibid., 53.
} 
the way we receive from God." They cite the five spirituality typologies of Urban T. Holmes and added a sixth in order to give deeper understanding. Drawing from the example of the life of Christ, they conclude that we all experience God through prayer, study of scripture, the Lord's Supper, fasting/abstinence, Christian conference, and acts of mercy. Our approach to God is through Head, Heart, Pilgrim, Mystic, Servant, or Crusader spiritualities and whereas all may possess all six types, there is a dominant type in each of us. ${ }^{2}$

Understanding my spirituality web has given insight into how best I can use my spiritual gifts relative to who I am as a person. In my experiences of Prayer, Study, the Lord's Supper, and Acts of Mercy I approach God with Heart Spirituality; but in Fasting and Conference my approach is Pilgrim. This is illustrated in table 1.

Table 1. Spirituality Web

\begin{tabular}{|l|l|}
\hline \multicolumn{1}{|c|}{ Heart Spirituality } & \multicolumn{1}{c|}{ Pilgrim Spirituality } \\
Focus is on relationship with Jesus & A person seeks meaning \\
Faith sharing is essential & A person looks for answers \\
$\begin{array}{l}\text { There is a strong commitment to prayer } \\
\text { for others }\end{array}$ & $\begin{array}{l}\text { There is openness to a wide variety of } \\
\text { Experience rather than study is preferred } \\
\text { to knowing God } \\
\text { There is a praise orientation }\end{array}$ \\
\hline
\end{tabular}

Source: Dick and Miller, 74.

${ }^{1}$ Ibid., 73.

${ }^{2}$ Ibid. 


\section{Task Type Preference}

Task Type preferences describe the way we do the work for which we have been equipped. ${ }^{1}$ Dick and Miller describe four Task Types, namely, Project, Work, Process, and Fellowship. In understanding one's own task type one is able to better guide others to work more efficiently and more productively. It also has the potential of alleviating tension within working groups by assigning people with similar task type preferences.

My dominant Task Type Preference is Project. This means that I prefer to be involved in a task from start to finish. I desire to be part of the planning, implementing of the plans, and evaluating the results and the processes involved in a project. However, as with other aspects of service, one has the potential for adaptability. Circumstances may dictate that we function in a Work, Fellowship, or Process Task Type because it is expedient to do so. Tasks that are too open-ended and do not have a definite shut-off point are not ideal for Project Type Preference because they prefer clearly defined boundaries within which they can work to achieve a definite goal. ${ }^{2}$

\section{Personal and Spiritual Goals}

\section{Need for Self-Assessment}

The problem with pastors is that some think they have been called to save the world and because of this realization their focus is nearly always on those who are in need of salvation. Some feel that if they are not out seeking the lost they are not fulfilling the "call" and the Gospel commission of Jesus Christ, which is to make disciples of all

\footnotetext{
${ }^{1}$ Ibid., 87.

${ }^{2}$ Ibid., 91 .
} 
nations (Matt 28:19). A sense of satisfaction comes only from knowing that all the visits that could possibly fit into one day have been made, that as many committees as possible have been set up and chaired, that every emergency has been responded to, and another powerful and uplifting sermon has been preached. There have been times when the going has gotten so tough that I wonder to myself what it would be like to be a lay member once again. The sense of guilt that seems to be inherent in ministry for not being able to meet everyone's need all the time prevents many pastors from being as fulfilled and satisfied as I believe God intended. This feeling of letting down the side and disappointing those who have expectations has caused many ministers to fail to conduct proper and meaningful assessments of themselves and their needs. I have welcomed the times when I have been given permission to step back and self-assess.

Richard Swenson helps us to understand that it is not healthy to go on living in guilt for not being able to do "all things through the obligations that strengthens us." $\mathrm{He}$ highlights the need for "margin." In his definition he states that "Margin is the amount allowed beyond that which is needed. It is something held in reserve for contingencies or unanticipated situations. Margin is the gap between rest and exhaustion, the space between breathing freely and suffocating. It is the leeway we once had between ourselves and our limits."1

Self-assessment and the need for "margin" have been made more meaningful for me by the discovery of discussions on the spiritual disciplines. Even though the individual elements were known and are practiced at different times in my life, they were

\footnotetext{
${ }^{1}$ Richard A Swenson, Margin: Restoring Emotional, Physical, Financial, and Time Reserves to Overloaded Lives (Colorado Springs, CO: NavPress, 1992), 91-92.
} 
never looked upon collectively as disciplines for spiritual growth. It is true that one cannot appreciate the benefits of anything unless one understands the reason for its existence. I agree with Donald Whitney who states, "Discipline without direction is drudgery.",

It is necessary therefore, to understand the purpose for the spiritual disciplines. I think it must go without saying that the primary purpose must be to become like Christ in character and behavior. Mulholland takes it one step further and suggests that it is a "process of being conformed to the image of Christ for the sake of others." He further adds, "Just as a journey from one place to another requires varied sets of disciplines for successful completion ... so the Christian journey has its own sets of disciplines which enable the pilgrim to progress through the stages of the spiritual path toward wholeness in Christ."3

One cannot ignore this primary purpose for it is the goal of the Christian life. Not a goal that is only finally achieved at the Second Coming of Christ, but one that is worked toward and reached for by the persistent disciple. Donald Whitney reminds us of Paul's counsel to Timothy, "Discipline yourself for the purpose of godliness."4

${ }^{1}$ Donald S. Whitney, Spiritual Disciplines for the Christian Life (Colorado Springs, CO: NavPress, 1991), 15.

${ }^{2}$ Mulholland, 12 [Italics supplied].

${ }^{3}$ Ibid., 75 .

${ }^{4}$ Whitney, 16. 
A second purpose for the disciplines is that it gives freedom from the bondage of self-interest and fear. ${ }^{1}$ When one is able to focus on Christ and spiritual themes one is able to rid oneself of the burdens of sin and the condemnation that accompany them, thus producing an inner cleansing. Guilt and self-condemnation are two enemies of the soul that can crush any worker for God who feels that he or she is unable to meet the demands of society and those to whom there is an obligation.

Numerous authors have written on the subject and have outlined the benefits of applying the disciplines to one's life. There are however, difficulties that are encountered in attempting to apply the disciplines. Richard Foster suggests that there are two reasons for this. First, he states that people doubt their ability to reach beyond the physical realm because of the materialistic society in which they find themselves. ${ }^{2}$ The common thought among modern day scientists is that the physical world is all that exists and that the spiritual realm is a fantasy of the religious minority.

Secondly, he suggests that there is difficulty because many no longer know how to explore the inner life. ${ }^{3}$ This is a modern day phenomenon, for those of previous generations had the disciplines as part of their culture and so it came natural to them. Today, each discipline has to be taught. The obvious benefits that previous generations took for granted are now not appreciated. Mysticism is looked upon with suspicion and

\footnotetext{
${ }^{1}$ Richard J. Foster, Celebration of Discipline: The Path to Spiritual Growth (San Francisco, CA: HarperCollins, 1998), 2.

${ }^{2}$ Ibid., 2.

${ }^{3}$ Ibid., 3.
} 
anything that seems to give credence to any New Age or Eastern philosophy is dismissed by the Christian. Therefore the searching of the inner self remains alien to those who perhaps need it most.

Writers on spirituality and spiritual formation are of differing opinion as to what are the most important disciplines. Some go as far as listing Fellowship, Journaling, and Learning as being important, whereas others suggest that Confession, Simplicity, and Submission are important, and still others list Solitude, Silence, and Retreat. ${ }^{1}$ However, despite the differing opinions, all agree on the basic disciplines of Bible Study, Prayer, Meditation, and Worship, to name but a few.

Before I discuss what I perceive to be my spiritual needs I must identify the fact that I realize that my spiritual needs are influenced by my temperament type and my worldview. My temperament type is ISTJ, and that means that as an ST (Sensing/Thinking) person my spiritual needs are best met through practical, concrete, and literal terms. I like to analyze situations based on facts that are reasonable.

This Doctor of Ministry degree has broadened my understanding of worldview. Worldview may be defined as the "basic foundational concepts that underlie all we think and do. They are mostly unconsciously held, and picked up from society."2 My understanding of worldview and how it influences behavior is a development of the thoughts of Paul Hiebert, a missiologist who espoused the idea discovered from his encounter with the Indian culture, of a separation between the divine and human realms,

${ }^{1}$ Comparing the contents of Mulholland, Foster, and Whitney.

2Jon Dybdahl, definition given in class lecture in "Spiritual and Theological Basis for Ministry" at Newbold College, Bracknell, England, 3 July 2002. 
and the need to bridge the gap. Hiebert identified this gap as the "excluded middle" (see table 2). In the Eastern culture this middle is filled by belief in spirits of ancestors, angels, dead saints, and demons, and these bridge the gap between the divine and the human realms, allowing contact and communication between the two, but in Western culture these beliefs are dismissed and there is nothing to substitute for the supernatural.

Table 2. The Excluded Middle

\begin{tabular}{|c|c|c|}
\hline & Personal & Impersonal \\
\hline $\begin{array}{c}\text { Divine/Super } \\
\text { Human }\end{array}$ & God/Jesus & $\begin{array}{c}\text { Karma/Gravity/Universal } \\
\text { Force }\end{array}$ \\
\hline $\begin{array}{c}\text { The Excluded } \\
\text { Middle }\end{array}$ & Angels/Prophets/Dreams/Conscience & Meditation/Horoscopes \\
\hline $\begin{array}{c}\text { This } \\
\text { World/Nature }\end{array}$ & $\begin{array}{c}\text { Human Relations/Psychology/ } \\
\text { Anthropology }\end{array}$ & $\begin{array}{c}\text { Maths/ } \\
\text { Chemistry/Physics }\end{array}$ \\
\hline
\end{tabular}

Source: Hiebert, 35-37.

Dybdahl suggests five models of worldview. Worldview determines whether or not people believe that God interacts in human affairs. As table 3 illustrates, the Agnostic and Deistic worldviews do not believe that God has contact with humans (shaded areas representing contact). The Agnostic view, denying the existence of the divine, and the Deist view, denying any interaction with the divine, isolates humans from the divine. The Magical worldview however, only allows contact and interaction with the right formula and when certain conditions are met. The Medieval worldview is ignorant of the possibility, but the Christian Theist worldview allows contact.

\section{$35-37$.}

${ }^{1}$ Paul Hiebert, “The Flaw of the Excluded Middle," Missiology 10, no. 1 (1982): 
Table 3. Dybdahl's Models of Worldview.

\begin{tabular}{|c|c|c|}
\hline & Personal & Impersonal \\
\cline { 2 - 3 } Atheistic and Agnostic \\
Worldview & & \\
\cline { 2 - 3 } $\begin{array}{c}\text { God does not exist and man } \\
\text { has no contact with the divine }\end{array}$ & & \\
\hline
\end{tabular}

\begin{tabular}{|c|c|c|}
\hline $\begin{array}{c}\text { Medieval Worldview } \\
\text { The divine and the spirit world } \\
\text { has no contact with man }\end{array}$ & \multicolumn{2}{|c|}{} \\
\cline { 2 - 3 } & & \\
\hline
\end{tabular}

Deistic Worldview

God is creator but has no

further contact with creation

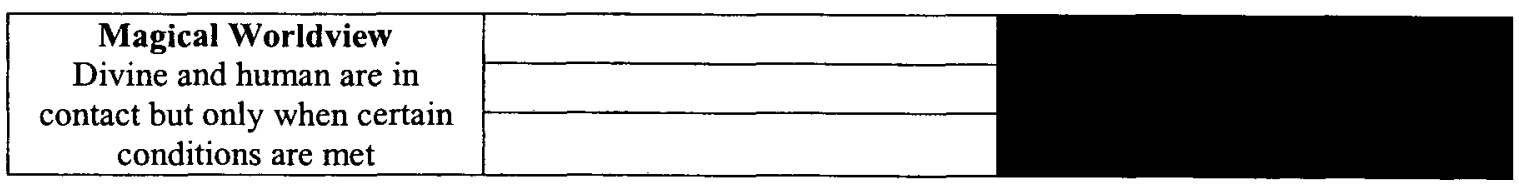

\section{Christian Theist Worldview \\ The divine and human are in \\ constant contact and communication}

Source: Jon Dybdahl, class lecture on, "Spiritual and Theological Basis for Ministry" at Newbold College, Bracknell, England, 3 July 2002.

Having considered the models presented I am of the opinion that my personal worldview is an "upgrade" of the Deistic Worldview. This is the belief that God, as Creator, made the world with laws to govern its operation. There was no need for God to continually intervene in a world that was perfect; therefore he left it to run. If it were not so then God is to be blamed for everything, whether good or bad. He is responsible for pain and evil just as a father who allows his young infant to wonder into danger without putting up a safety barrier or set ground rules, is responsible for any hurt to that infant. However, because mankind is aware of the laws that govern creation he takes responsibility for his own actions. 
Having violated those laws man found himself in a position of helplessness, and so it became necessary for God to intervene in man's affairs. God's intervention was for the purpose of re-establishing relationship with fallen man by instituting the Plan of Salvation. In the perfect world God's interaction with the human race was purely relational and not to keep the world in order.

This worldview impacts my spirituality. It impacts by giving me responsibility for my sin. I cannot blame anyone else. It is my fault and I can do nothing to remedy my situation except by accepting the intervention of God into my world, to establish a relationship with me. Whatever the condition of my world, God has come for a relationship, and my ministry is to present to the world a God who wants a relationship.

I perceive then, that my greatest personal and spiritual need is to apply the spiritual disciplines to my own personal life, taking into account my temperament and worldview. Even though the spiritual disciplines are so numerous I would like to focus on what I perceive to be the most important ones for my growth, namely, Bible study, prayer, and meditation.

\section{Deeper Personal Study of the Scriptures}

I love Bible study. Very few activities give me greater satisfaction than to spend a couple of hours studying the Word of God. My temperament type is IST, which suggests that I like to be alone in deep analysis of the Scriptures, but I have found that increasingly my study habits are dictated by the time between one sermon and the next. As a student, I loved the biblical languages and the tools for biblical hermeneutics, but pressure of time and a crowded agenda prevents one from mining for the gems so necessary for personal soul building. 
As much as I would like to believe that it is possible to study just for my own personal benefit, I do realize that my deepest blessings are always shared with the church in some form and at some time, sooner or later. We cannot deny the fact that we receive in order to give.

Routine has its potential pitfalls. Doing something in the same way over a sustained period can create a sense of indifference. This sense of indifference does not mean that we are not performing well; on the contrary, we are doing a fine job, but the routine has robbed us of the benefits that should be derived from the experience. I have attempted many times to read the Bible through from Genesis to Revelation in one year, and I have also failed many times because of the routine and because of the distractions. The routine of reading is not as rewarding as the routine of study. Donald Whitney reminds us of the distinction between reading and studying. He likens reading to cruising a clear lake in a boat, and studying, to cruising the same lake in a glass bottomed boat. ${ }^{1}$ The destination may be the same but the experiences cannot be compared.

Perhaps the clearest and most practical guide to meaningful Bible study is that outlined by Mulholland. He addresses the subject of Spiritual Reading, reading not just for information in order to control our environment, but also for spiritual nurture.

Spiritual reading is the discipline of openness to encounter God through the writings of the mothers and fathers of the church, beginning with the scriptures. In spiritual reading the text becomes the means of grace through which we encounter the God who has spoken us forth into being and who continues to speak to us to shape us in the image of Christ for others. In brief, the text opens us to God's control of our lives for God's purposes. This is a radical reversal of the dynamics of an informational culture in which our possession and use of information enables us to impose our purposes upon the world of our activities. ${ }^{2}$

${ }^{1}$ Whitney, 35.

${ }^{2}$ Mulholland, 110-11. 
Table 4. Components of Bible Study

\begin{tabular}{|l|l|}
\hline COMPONENTS & \multicolumn{1}{c|}{ DESCRIPTION } \\
\hline Silencio & $\begin{array}{l}\text { Prepares the heart for receiving what the text has to say } \\
\text { to us. This step rids me of all preconceived ideas and } \\
\text { ambitions regarding the study and helps me to rely totally } \\
\text { on the inspiration of the text. }\end{array}$ \\
\hline Lectio & $\begin{array}{l}\text { The actual reading of the text. This component addresses } \\
\text { the Sensing needs of my temperament because it gives } \\
\text { hands-on, practical participation in the search for } \\
\text { godliness. }\end{array}$ \\
\hline Meditatio & $\begin{array}{l}\text { This step is perhaps the most exciting for me because it } \\
\text { gives opportunity for me to mine for further truths which } \\
\text { are not found on the surface. This stimulates my } \\
\text { Thinking process and meets a need that surface reading } \\
\text { cannot satisfy. }\end{array}$ \\
\hline Oratio & $\begin{array}{l}\text { This component is a "slow-me-down" component. It } \\
\text { reminds me that I must stop and respond to God for what } \\
\text { I have gleaned. My underdeveloped Feeling needs are } \\
\text { met through thankfulness, expressions of love and joy, or } \\
\text { just making a commitment based on what I've learned. }\end{array}$ \\
\hline Contemplatio & $\begin{array}{l}\text { Here is where I must learn to wait on God to see what he } \\
\text { wants me to do with what I have learned. My } \\
\text { underdeveloped iNtuition needs are met at this level, if I } \\
\text { allow it. }\end{array}$ \\
\hline Incarnatio & $\begin{array}{l}\text { This stage is where I allow God's Word to transform my } \\
\text { being. It is fulfilling my pledge to be obedient to what I } \\
\text { hear. The blessing is to those who, not only hear, but } \\
\text { also do the will of God. }\end{array}$ \\
\hline
\end{tabular}

Source: Adapted from Mulholland, 113.

Mulholland expands on the Latin term for spiritual reading, lectio divina and its four components. Each component addresses the Sensing-iNtuition and ThinkingFeeling needs of the seeker of spiritual growth. The expanded components are silencio, lectio, meditatio, oratio, contemplatio, and incarnation, as illustrated in table 4. Each component is a necessary step in the spiritual discipline of studying the Bible for spiritual nurture and not just for information. 
As I practice this discipline on a regular basis I believe that this spiritual need will be met and spiritual growth will continue on an escalating scale.

\section{Consistent Personal Prayer Life}

Every Christian knows that prayer is an integral part of spiritual development. I have not yet met anyone who does not sense the need to improve on their prayer commitment and to improve the quality of their prayers. All agree that there is always room for improvement.

As far as I am concerned, when it comes to prayer, it is not so much longer prayers, but more effective prayers, and a more consistent prayer life that is needed. As with Bible study, it is so easy to fall into a pattern that soon becomes routine and mundane. Prayer then becomes mechanical and dry and soon it appears to be ineffective.

In his book Understanding Prayer, Edgar Jackson helps people understand that the attitude and mood one brings to prayer determines, to a great extent, the outcome. The attitude of Jesus is used as a model for all who would venture onto this ground. He states that Jesus' attitude was firstly, one of total trust in the efficacy of prayer. "He believed that in prayer we align ourselves with infinite power and wisdom. In prayer we are fulfilled because we become one with God. In prayer our potential as spiritual beings is realized because we yield to God that his will may be made known in and through us. The mind of Christ was a believing mind. We gain insight into the proper attitude toward prayer by looking at the quality of his mind at prayer."1

${ }^{1}$ Edgar N. Jackson, Understanding Prayer (London: SCM Press, 1968), 143. 
So, as it was with Jesus, prayer places us in the very presence of God, and there should be no feeling of isolation.

The activity of prayer is something that often can become a burden if it is allowed to become purely mechanical. But Jackson gives the reminder that "prayer is not something we do, ... it is something that happens to us," and that it is not something external but rather, internal because it seeks to put the inner spirit in tune with God, who occupies the inner man. ${ }^{2}$

Other attitudes that are highlighted by Jackson are openness in our approach, making sure to ask the right questions to God, and not being restricted by our rational and science-oriented mindset. Also, the attitude of hungering and thirsting for righteousness is essential. If we do not long to be filled when we approach God then we will leave still destitute. This leads to the final attitude that is emphasised, and that is an attitude of expectancy. Heb 11:6 states that belief in the existence of God and his ability to reward is a prerequisite to answered prayer. This expectancy is the fulfilment of God's will and not our will. Jackson adds, "But prayer is a matter of total self-surrender. The art of letting go must be mastered. We cannot force prayer into our mould and expect the will of God to be made manifest. Our responsiveness must be like shifting into a spiritual overdrive where we move beyond the conflicts of interest that grow from trying to impose our wills upon the universe. Prayer finally leads man to surrender his wilfulness,

\footnotetext{
${ }^{1}$ Ibid., 147.

${ }^{2}$ Ibid., 9.
} 
false pride, and limited judgments so that he may be completely responsive to God's will, even though this may involve a cross."

It is refreshing to note that, according to Michael and Norrisey, our temperament types determine our preferred needs in prayer. This conclusion was arrived at from the results of a prayer project conducted in 1982. Over the course of the year people of different temperament types were asked to react to suggestions of different prayer forms. Five forms were suggested-Benedictine, Ignatian, Augustinian, Franciscan, and Thomistic. ${ }^{2}$ The Benedictine and the Ignatian forms relate to my personality preference-the SJ.

The Benedictine prayer form is the Lectio Divina that has already been discussed in the context of Bible study. This is good news for me in that this method is able to tie my prayer and spiritual reading habits together. The principles that govern my productive Bible study sessions are the same as when I pray.

The principle of the Ignatian prayer model is also based on scriptural narrative. Ignatius of Loyola taught that one should make the scriptural scenes come alive in prayer by placing ourselves in the scenes that are being described. This exercise gives us an encounter with God, and thus allows us to petition and praise God for felt needs and blessing, and also to be closer in tune with his will.

${ }^{1}$ Ibid., 146.

${ }^{2}$ See Chester P. Michael and Marie C. Norrisey, Prayer and Temperament: Different Prayer Forms for Different Personality Types (Charlottesville, VA: The Open Door Inc. 1991) for more details of the different prayer forms. For the purposes of this paper I shall only discuss the types that relate to my own personality type preference. 


\section{Practice of Meditation}

The practice of meditation is not something that I can truly say that I have understood in the past. Maybe it is because, like so many others, I have associated it with Eastern mysticism and transcendentalism. My temperament type preference suggests that I prefer something that is practical, concrete, and hands on, and so the idea of deep meditation sounded to me like something that is supposed to put me to sleep. However, from my reading I have learned that sleep is not the object, but rather, a deeper and more practical experience with God. I have also learned that true meditation has close connections with the study of the Word and with prayer.

Richard Foster has been very practical and enlightening in his approach to the subject. In Celebration of Discipline, he states, "Christian meditation, very simply, is the ability to hear God's voice and obey his word." He further adds that when meditate we "create the emotional and spiritual space which allows Christ to construct an inner sanctuary in the heart." 2 This thought helps to dismiss the idea that meditation has to do with emptying the mind in order to reach Nirvana or some higher level of existence, but it instead allows Christ to come into my heart for fellowship.

It is refreshing to realize that what I have been doing every time I study the Word of God, namely, just contemplating the meaning, is called meditation. And if my study is practical and addresses the realities of life, then, my meditation is firmly rooted in life. ${ }^{3}$

\footnotetext{
${ }^{1}$ Foster, 17.

${ }^{2}$ Ibid., 20.
}

${ }^{3}$ Thomas Merton, Contemplative Prayer (Garden City, CA: Doubleday, 1969), 37, quoted in Richard J. Foster, Celebration of Discipline: The Path to Spiritual Growth (San Francisco, CA: Harper Collins, 1998), 22. 
However, as a spiritual discipline what I need to do now is make it a more deliberate part of my daily devotion.

\section{Learning from Jesus}

Finally, what I perceive to be an important need in my spiritual formation is to learn from the example of Jesus. Jesus was much disciplined in spirituality. He learned obedience through the things that he suffered (Heb 2:10). His spirituality did not come automatically. Many instances are recorded in the Gospels of Jesus taking time out for spiritual renewal. To name but a few, Matt 4 records him going into the wilderness alone at the start of his public ministry. In chapter 14, Matthew records that on hearing of the death and burial of John the Baptist he withdrew to a solitary place alone. After the crowd had found him he fed them and dismissed them, and he went up into a mountain by himself to pray. In the final hours of his time before his death he found it necessary to pray by himself (Matt 26).

Mark reminds us that while at the home of Simon and Andrew, "Very early in the morning, while it was still dark, Jesus got up, left the house and went off to a solitary place, where he prayed" (1:35 NIV). He was gone for so long that a search party was sent out for him. And chapter 6:31 reminds us that Jesus took time out with his disciples despite the demands of the crowd.

Luke 5:16 makes it clear that it was Jesus' practice to take time out in lonely places to pray. The night before he chose the twelve apostles was spent in prayer on a mountainside (Luke 6:12).

If Jesus, who came to save the world, saw the need to take time for renewal, then so must I. With this time for spiritual renewal being a regular part of my ministry I can 
then take positive steps toward achieving the goal of having an increasingly productive ministry: one that does not stagnate or become static, but one that is ever growing and changing for the better.

\title{
Theological Understanding
}

\author{
Ministry
}

\section{Jesus' Ministry}

It is practically impossible to have a correct theological understanding of ministry without first looking at the example of ministry set by Jesus, himself. His ministry example was in direct contrast to that of the Pharisees, scribes, and teachers of the law in his day. He warned his followers not to follow the example of these community leaders who were quick to display their qualifications before everyone. Concerning the leaders of his day, Jesus said, "Everything they do is done for men to see: they make their phylacteries wide and the tassels on their garments long; they love the place of honor at banquets and the most important seats in the synagogues; they love to be greeted in the market places and to have men call them 'Rabbi"' (Matt 23:5-6 NIV).

This example of ministry is purely self-centred and is diametrically opposed to Christ's way of ministering. The time he spent with his disciples was to demonstrate to them what true, effective ministry was all about. Many of them had adopted the concept of ministry that was held so commonly in their time, and, indeed is still held today. A hierarchical, status conscious, ministry is what Christ warned his followers against. They debated among themselves as to who would be the greatest in the kingdom (Mark 9:3337). Some wanted to sit on the right hand and on the left hand in the kingdom (Mark 10:37), and others refused to wash one another's feet (John 13:1-17). 
Christ's concept of ministry is one of altruistic service. The key words in his mission statement might be considered to be, "seek," "serve," and "save." In his counsel to his disciples, found in Mark 10:42-45, he said, "You know that those who are regarded as rulers of the Gentiles lord it over them, and their high officials exercise authority over them. Not so with you. Instead, whoever wants to become great among you must be your servant, and whoever wants to be first must be slave of all. For even the Son of Man did not come to be served, but to serve, and to give his life as a ransom for many."

\section{New Testament}

It is noted that in the New Testament (NT) times there were four Greek words that were available to the NT writers to express the concept of ministry. The Greek words, telos, time, arche, and leitourgia are all terms used to describe official positions, or ministries, whether appointed or voluntary, in the temples, governments, community, or civil services. However, it is pointed out that none of these terms were used by the NT writers to describe the ministry of the church for the sole purpose of not wanting to make any distinction between the official ministry of a person or group and that of any believer. ${ }^{1}$ Instead, the word that is used to describe the ministry of the church in the first century was diakonia, a word that is very rarely used in the LXX (Septuagint), yet one that denotes service, especially that of waiting on tables. Whether it was a special ministry or a general ministry, all were diakonia.

(1992), 4:835.

"R. Eduard Schweizer, "Ministry in the Early Church," Anchor Bible Dictionary, 
The New Testament Church then, following the example of Jesus, perceived their ministry, whether it be in the capacity of apostle, bishop, elder, or deacon, as altruistic service to their fellow humans and, in turn, to God. Converts to Christianity soon followed suit and this common practice caused the church to grow rapidly.

The apostle Paul, a convert to Christianity, in discussing the concept of ministry, broadened it to encompass all the workings of the Holy Spirit in the church-Spiritual Gifts. He taught that all gifts were of equal value and for the benefit of the whole church (1 Cor 12:27, 28). Gifts were to create unity in the church and prepare the church for works of service (Eph 4:12-13).

\section{Ministry and Mission}

I am of the opinion that the development of a theology of ministry must be based, not only on Christ's example but also on his directives. If he came to teach the way, then we must be willing, as disciples, to follow the way. His example is clear, his definitions are clear, and his directives are clear. I believe that Christ's directives are our basis for ministry.

Christ's directives are mission based. They are intended to impress others with the love of God. Christ's mission was to seek and save the lost, and his commission to the disciples was, to do the same. In Matt 28:19, 20, I understand the purpose for the existence of the church is to make disciples. "Therefore go and make disciples of all nations, baptizing them in the name of the Father and the Son and the Holy Spirit, and teaching them to obey everything I have commanded you. And surely I am with you always, to the very end of the age." 
Without this text, and similar ones, a theological basis for ministry would be very short lived. This commission gives the Christian minister vision and energy. The vision is gained from the scope of the task and the energy is gained from the urgency of the commission. Matthew further emphasizes the scope and urgency in chapter 24:14, "And this gospel of the kingdom will be preached in the whole world as a testimony to all nations, and then the end will come." This commission is the driving force behind both my personal ministry and my professional ministry. The apostle Paul, in writing to Timothy, encourages him to "preach the Word; be prepared in season and out of season" (2 Tim 4:2). This preparedness creates a sense of urgency for the preaching of the Gospel. This urgency forms part of the basis for ministry and without this basis there is no meaning or reason for ministry.

The command to make disciples of all nations (Matt 28:19, 20) has a double emphasis for the professional minister and these emphases incorporate all the spiritual gifts given to the church for the purpose of ministry. These emphases are both outwardly focused and inwardly focused. They are outwardly focused because they emphasize the evangelistic nature of the church, and they are inwardly focused because they emphasize the spiritual nurture necessary for healthy ministry to take place.

In the first emphasis Matthew records the words of Jesus' commission, poreuthentes oun matheiteusate panta ta ethnei, "having gone then, disciple all the nations." Poreuthentes (having gone) is written in the aorist tense and suggests that the action has already started and is continuing indefinitely. ${ }^{1}$ This presupposes, then, that the

\footnotetext{
${ }^{1}$ H. E. Dana and Julius R. Mantey, A Manual Grammar of the Greek New Testament (Toronto: The Macmillan Company, 1957), 193.
} 
disciples have already gone and are already a part of the nations that they are called to make disciples of. This part of the commission challenges the minister to be global in his thinking and be willing to integrate with the nations and cultures of the world. This means that the success of missions can only be determined by the extent to which we are part of the culture of those we are trying to impress with the Gospel of Jesus Christ. As a commissioned disciple and a commissioned professional I cannot afford to be aloof from those around me. My ministry is to know them, integrate with them, and impress them with the truth of a loving Savior, so much so that they are baptized in the name of the Father, Son, and Holy Spirit.

The commission to go into the world, then, is the command to make disciples. As a professional minister my job description is to aim to integrate the disciples into the cultures around us. This means leading the people to an understanding of, and an appreciation of, differences in ethnicity and cultures, thus causing them to share personally in the vision and the energy of the mission of the Christian church.

The second emphasis is on the keeping of disciples. Matthew states the words of Jesus as saying, didaskontes autous teirein panta hosa eneteilamein humin, "teaching them to obey everything I have commanded you." Teaching the cultures to observe all the commands of Jesus follows the work of integrating with the cultures. Didaskontes, "teaching" is in the present indicative mood, which implies that the action begins at a particular moment in time and continues indefinitely. ${ }^{1}$ This means that ministry is never

\footnotetext{
'Ibid., 181.
} 
fully accomplished as long as people are being saved and are in need of teaching. So, preaching and teaching go hand-in-hand.

The teachings that the church is commissioned to give must have as their aim the spiritual nurture of the believer. Irrespective of culture or ethnic origin all new believers must know that spiritual maturity is their goal. The apostle Paul, in writing to the Ephesians stated that spiritual gifts of apostles, prophets, evangelists, pastors, and teachers were given for the purpose of preparing the church for works of service that will build up the church in unity of faith and knowledge of the Son of God. This ultimately leads to maturity in becoming more Christ-like. ${ }^{1}$

The nurturing of the church to maturity through the teachings of the church is the role of the Father, Son, and Holy Spirit working corporately in the life of each believer. Edmund Clowney portrays the Father as one giving instruction, direction, and protection through his word, to the church as one would to a child who observes the work and vocation of a loving parent. The Son, Jesus Christ is portrayed as the example of who the Father is. He invites the church to follow his example thus becoming like him and then understanding who the Father is. Finally, the Holy Spirit, who was the active agent at creation, is the active agent in the nurture of the believer. He is described as the Spirit of Truth who teaches all things. ${ }^{2}$

${ }^{1}$ See Eph 4:11-13.

${ }^{2}$ Edmund P. Clowney, The Church, Contours of Christian Theology, ed. Gerald Bray (Leicester, UK: Inter-Varsity Press, 1995), 138-43. 
The minister as preacher and teacher aims not only to lead the disciples to find personal, spiritual strength in Christ, but also to find corporate, spiritual unity in cultural diversity. Clowney suggests,

The transcending identity of the church does not erase ethnic ties, but it bars them from demanding primary, and therefore idolatrous, loyalty. Those who are united in the catholicity of God's family, of Christ's kingdom and of the Spirit's fellowship cannot in good conscience exclude from the table and roof of the brotherhood fellow-Christians from ethnic groups that are hostile to their own. Certainly, practice will mean more than pious theory, but the theory, too, must be deeper. . . . Until we have a deep biblical sense of the corporate identity of the new people of God, we will not be able to present the gospel of peace on the front lines of our "culture wars." The true drawing power of the church transcends the cultural enclaves of contemporary society to dissolve the hatreds of a fallen world in the love of Christ. ${ }^{1}$

In a multicultural world the minister is to train the disciples to be able to go into the entire world, with an open and unprejudiced mind, and make other disciples, regardless of ethnic origin, and as we grow together we will "all reach unity in the faith and in the knowledge of the Son of God and become mature" (Eph 4:13). This maturity means that the minister's aim is for the disciples to reach their highest potential. Selfdevelopment and self-improvement must be the goal because "higher than the highest human thought can reach is God's ideal for his children."2

Not only is the minister's calling to lead the church to successful evangelism and nurture, but it must also be to lead it to organizational strength. Unity in diversity is contingent upon unity organizationally. By this I do not mean that everyone does things in the same way but rather, in diversity, all are moving along in the same direction. This demands dialogue, openness, and acceptance.

${ }^{1}$ Ibid., 163-64.

${ }^{2}$ Ellen G. White, Education (Mountain View, CA: Pacific Press, 1952), 18. 
In organizing the disciples it would appear that Christ was laying the foundation for organizing the church. In ordaining the twelve (Matt 10) he set the precedent for organization, for it was the twelve apostles who gave the direction for the ordination of the seven deacons (Acts 6:2). Organization is seen in the distribution of goods for the poor (1 Cor 16:1), the commissioning of Paul and Barnabas for their missionary journey (Acts 13:2), the accountability to the other disciples for suspected errors in doctrine (Acts 15:2), and even coming together at the Jerusalem council to present a united voice to the world church (Acts 15:13).

When studying the history of the church it is clear that organizationally, the church has evolved over the centuries. The organization and structure of the church in the early days of its existence matured as the need arose throughout the centuries. From twelve apostles governing the church from one location in Jerusalem, it has grown to numerous leaders and committees governing numerous sub-organizations from numerous parts of the globe. Organization then must reflect not only chronological difference but also cultural differences within the world church.

My theology for ministry then is based on the commission of Christ to the church to go and make disciples, which is evangelism; teach them to observe the commands of Christ, which is nurture; and finally, to organize according to the examples that Christ left his disciples.

\section{Church}

The two concepts of church and ministry are very closely related. The relationship is so close that it is difficult to conceive one without the other. It is my belief that this close relationship is there because Christ initiated both. Church is the product of 
Christ in that he created it when he called his disciples, and ministry comes as a result of Christ commissioning his church to serve others.

\section{Concept of Church in the Old Testament}

The Christian church as identified in the New Testament (NT) is an outgrowth of the people of God in the Old Testament (OT). In the Old Testament the people of God are seen as a community of believers who have a common focus and a common relationship with one another and with God. As long as this two-dimensional relationship is maintained the church maintains its identity.

The need for this identity is seen in God's dealing with the human race in the Garden of Eden. Before disobedience the relationship between Adam, Eve, and their Creator formed a community. The wholesome nature of this community was affected by sin and this prompted the intervention of God with the aim to restore the community and the relationship. It is also seen in God's calling of Abraham. He was not called in isolation, but rather as a community. He and his wife were called and promises were made to both. The focus of God was not so much on Abraham as an individual but on Abraham as a leader of a community. Gen 18:18-19 states, "Abraham will surely become a great and powerful nation and all nations on the earth will be blessed through him. For I have chosen him, so that he will direct his children and his household after him to keep the way of the Lord by doing what is right and just, so that the Lord will bring about for Abraham what he has promised him."

The church as a community motif is seen throughout the OT. It has been the strength of the community and its relationship with God that has given identity to Israel as the people of God. Moses, called to lead the people of Israel as a community, gave 
clear and specific instructions on the ingredients necessary to form a great nation. It was very clear that true success would only come as they kept the covenant relationship with their Creator. The Ten Commandments were given to remind them of the necessary relationship - to love the Lord with heart, mind, and strength, and to love one's neighbor as one's self. In fulfilling this law the community of Israel was to shine their light to the surrounding nations, thus ministering to them with the love and knowledge of God. "Arise, shine, for your light has come, and the glory of the Lord rises upon you. See, darkness covers the earth and thick darkness is over the peoples, but the Lord rises upon you and his glory appears over you. Nations will come to your light and kings to the brightness of your dawn" (Isa 60:1-3 NIV).

It is interesting to note that even though Israel was established as a nation they were still divided into smaller tribal and family units. This, I believe, enabled them to minister to one another and to the surrounding peoples more effectively. This demonstrates that the effectiveness of any community is determined by their ability to support one another and also to influence the communities around them. "In the last days the mountain of the Lord's temple will be established as chief among the mountains; it will be raised above the hills, and people will stream to it. Many nations will come and say, 'Come, let us go up to the mountain of the Lord, to the house of the God of Jacob. He will teach us his ways, so that we may walk in his paths.' The law will go out from Zion, the word of the Lord from Jerusalem" (Mic 4:1-2 NIV).

The blessings to Israel as a community and a people of God were realized during the reign of David as their king. He led the nation of Israel to acknowledge the relationship necessary for a strong spiritual community. However, after the disappointing 
reign of Solomon, his son, Rehoboam, demonstrated what happens when this twodimensional relationship is allowed to fall apart. The nation was divided and God was no longer their focus of worship. The prophets tried in vain to re-establish the community of believers for any sustained period. Love for God, their Creator, and truth and justice for their fellow man was the cry of the prophets. The evils committed in the nation by each successive king were always compared to the times of prosperity under the leadership of king David. After the Babylonian captivity the prayer of the prophet Daniel and the work of Ezra and Nehemiah were to re-establish Israel as the community of God.

\section{Concept of Church in the New Testament}

As has been mentioned previously, the church in the NT is an outgrowth of the people of God in the OT. The concept of community does not change in the transition between the two testaments but rather continuity is seen between the teachings of Christ and the NT writers and the teachings of the OT writers.

The NT concept of community began with the example and teachings of Christ. The OT expectation of the Messiah was a catalyst in the forming of the first Christian community of the twelve disciples and the other followers of Christ. It was because they expected the Messiah that they followed Christ, acknowledging that he was "the one Moses wrote about in the Law, and about whom the prophets also wrote- Jesus of Nazareth, the son of Joseph" (John 1:44 NIV).

Even though the disciples were all of varying backgrounds and families, and did not all know one another prior to meeting Jesus, yet they came together following one man. The relationship that they formed was based on their acceptance of Jesus as the Messiah. 
During the time of Christ the church identified with the synagogue. This "gathering" that began during the intertestamental era was not only a place of worship but it also identified the people of God. ${ }^{1}$ Jesus did not divorce himself from the synagogue but rather made it his custom to visit there, especially on the Sabbath, and was involved in the reading of the scriptures (see Luke 4:16-17).

It is evident that the synagogue was a place of communal activity and this image is portrayed in the concept of the church or ekklesia, "the called out." This term suggests that there is an act of separation from an undesirable group, and this separation has created an identity that has its own magnetic attraction. This attraction creates an assembly of those with similar calling. "The term ekklesia has a sacred history in the sacred writings. It stresses the distinctiveness of Christianity as compared to cultic societies."2 It is not used to identify any other religious group or organization and is, in fact, a secular term, adopted by the believers to identify not only a local gathering, but also the world gathering. ${ }^{3}$

In the book of Acts the activities of the church were described in communal terms. "When the day of Pentecost came, they were all together in one place" (Acts 2:1, emphasis mine); "They devoted themselves to the apostles' teaching and to the fellowship, to the breaking of bread and to prayer" (Acts 2:42, emphasis mine); and in Acts 4:32-35 it states, "All the believers were one in heart and mind. No one claimed

${ }^{1}$ E. Yamauchi, "Synagogue," Dictionary of Jesus and the Gospels (1992), 782.

${ }^{2}$ K. L. Schmidt, "ekklesia," Theological Dictionary of the New Testament (1985), ${ }^{3}$ Ibid., 398. 
that any of his possessions was his own, but they shared everything they had. With great power the apostles continued to testify to the resurrection of the Lord Jesus, and much grace was given them all. There were no needy persons among them. For from time to time those who owned lands or houses sold them, brought the money from the sales and put it at the apostles' feet, and it was distributed to anyone as he had need."

I agree with K. N. Giles in his statement concerning the New Testament understanding of the church where he writes:

The church is to be thought of as "the Christian community" because the early Christians were one in understanding that while men and women individually came to faith in Christ, this involved by definition becoming part of the family of God open to all people everywhere. The goal of the Christian mission was not to save individuals, though it involved this, but to call out a people for God's name. All the apostolic and postapostolic writers see this new community emerging out of historic Israel. It is therefore, like Israel, a corporate entity. The local gathering of Christians was important because this was where communal life in Christ was most personally realized; but for the early Christians, belonging to one community established by Christ was the primary reality. The modern Western individualistic spectacles through which we read the early Christian writings all too often blind us to seeing the profound communalism of early Christianity. ${ }^{1}$

The language of Jesus in his description of his followers had communal implications. He often referred to the disciples in pastoral terminology. In Luke 12:32, they are the "little flock", and in John 10 they are the sheep that belong to the sheep pen. Those who do not at present belong to the sheep pen will be brought into the pen in order that there may be one pen.

Another communal imagery that is used by Christ is that of wedding guests. In Mark 2:19 he defends his disciples' lack of fasting by stating that the guests of the

\footnotetext{
'K. N. Giles, "Church," Dictionary of the Later New Testament and Its Development (1997), 195.
} 
bridegroom cannot fast while the bridegroom is with them. The parable of the Ten Virgins in Matthew 25 describes the community of believers who are awaiting the coming of the bridegroom.

The concept of community in the New Testament then, was not only practiced by the disciples and the early church; it was in fact reinforced in the teachings and language of Christ. The church as a strong community was a crucial ingredient for individual spiritual growth. In isolation the sheep is lost and is in need of being found by the Good Shepherd and brought back to the fold or sheep pen. The coin that is lost in isolation is found and again placed with the other nine coins, and the son that was dead and lost is alive and found and re-established in the household. In the community there is security, as is illustrated in the case of the sheep; there is companionship, as is illustrated in the case of the coin; and there is nurture, as is illustrated in the case of the son.

\section{Personal Reflection}

When it comes to ministry in the general terms I believe that the Bible struggles to create a distinction between professional ministry and lay ministry. Ministry as a profession has created a perceptual problem for the church. By this I mean that because there are paid clergy who are involved in ministry it is so easy to perceive that ministry is for the professional and those who are not paid are only to support and encourage the professional, who, after all, is only doing his or her job.

Not wishing to repeat my previous discussion on my theology of ministry I would like to suggest and reiterate that church and ministry must go together like bread and butter. Whether we are lay or professional, if we are born again and a member of the church, we are called to ministry. Even though this may sound very cliché, it is my 
opinion that if more members of the church held this belief there would be greater effectiveness in our witness as Christians.

It is important to note that Jesus does not expect anything of us that he has not experienced himself. The power that accompanied Jesus also accompanies his church. At his baptism in the river Jordan the Holy Spirit rested upon him, anointing him for ministry (Matt 3:16). From that time Christ's ministry was Spirit led. In commissioning his disciples he commanded that they wait in Jerusalem for the promise from the Father-the promise of the Holy Spirit (Acts 1:4-5). John the Baptist prophesied that even though he himself had baptized with water the Messiah would baptize with the Holy Spirit and with fire (Luke 3:16). And so, on the day of Pentecost, when the church was together in one place, just as in the case of Jesus at his baptism, the Holy Spirit rested upon all of them, anointing them for ministry (Acts 2:1-4).

As a professional minister it is incumbent upon me to educate the church to this reality and to assure myself that this is not a one-time educational exercise but is something that is on-going with each new convert to the church. New members must be aware that the power given to the early church is not reserved for special people in the church but is available to all who are Christians.

It is so easy as a professional, to allow my profession to cause me to become a professional Christian. There is a danger of becoming so professional that I work my way out of the body of Christ-his church. I must teach the church and remind myself that the pastor is also a member of the church and that he also has a ministry that goes beyond his professional responsibilities. A right perception of the professional role will help to lessen the risk of being offended when the professional is addressed by the laity as 
brother instead of pastor. Surely, it is fair to suggest that the spiritual calling to Christian brotherhood and sisterhood supersedes that of the professional calling to pastor or teacher.

This chapter has been an interesting and enjoyable journey over grounds, some of which, I have not previously explored. There have been areas that have caused deep reflection and honest analysis. Even though this was the case, due to limitations on time and space, I found that I still did not venture to the depths of the valleys of feelings, thoughts, and aspirations that have long been hidden within, waiting to be expressed.

Spiritual exploration is something that everyone should engage in. Acknowledging the fact that God is not as divorced from the human realm as some people think is quite encouraging. A person's spiritual formation is shaped by historical background and experience. The variety of personalities and backgrounds means that we all get individual attention from a God who would not have it any other way.

The opportunity to explore my spiritual needs has been quite rewarding and became easy once I discovered my temperament type and spirituality web. These helped me to see that the methods that I had gained most pleasure and satisfaction from were, in fact, the methods that best met my spiritual needs. The challenge for me now, having discovered my needs, is to be disciplined enough to implement a strategy that will consistently boost me spiritually. Until now I have not found a formula to encourage consistency. It appears to lie within my own will and burden to succeed.

A spiritual foundation then, appears to be externally determined. It is also very subconscious. Not knowing what each day brings allows a person to view life in 
retrospect and see how God has carried each one through the sand dunes of time, and the footprints in the sand tell the story that the success of the journey was beyond control.

Not only is our spirituality individually determined, our ministry is also individually colored and expressed through our varied backgrounds and experiences. Though they may be, at times, quite challenging, and at others, most enjoyable, they are nevertheless, a part of the fabric that forms the tapestry of a ministry that may be often misunderstood but yet is every bit as authentic as the other person's.

My spiritual foundation for ministry has been influenced by my cultural and religious environment. In the next chapter I will explore further and in more specific detail the cultural and religious context in which my ministry in the Seventh-day Adventist Church is based. 


\section{CHAPTER III}

\section{RELIGIOUS AND CULTURAL ANALYSIS}

The cultural context of this project is important because it determines the style or approach that is adopted when ministering. It determines not only personal but also the collective style-the style for the individual church member and also for the local church as a whole.

\section{Definition}

Culture and religion are terms that have the potential to be emotive in all societies. They are two elements in life that are protected and sometimes defended to the death. Generally they are blamed for the eruption of many conflicts throughout history, and only a thorough understanding, and in many cases a conscious compromise, can quell the storms that have brewed in our desperate attempts to protect what people hold dear. To understand this passion it is necessary therefore to give a general definition of culture and religion.

Culture is important to society because it is their expression of who they are. Hofstede defines it as "the collective programming of the mind that distinguishes the 
members of one group or category of people from another." This "programming of the mind" is obviously manifested in one's behavior and in the expression of one's preferences. These behaviors and preferences are what we share communally, either in families, regional communities, or as a nation. Glasser defines culture as "the integrated system of learned patterns of behavior, ideas and products characteristic of a society."2 Following on from Hofstede's thought, this is born out in the suggestion that there is a parallel between culture and personality in that culture refers to the collective identity of humanity, whereas personality refers to the individual identity. So within a community its culture is determined by similarities in food choices, dress standards, codes of conduct, etc., whereas personality is those characteristics that are held privately. "Culture could be defined as the interactive aggregate of common characteristics that influence a human group's response to its environment. Culture determines the uniqueness of a human group in the same way personality determines the uniqueness of an individual."”

The Latin word, cultura from which is derived the English word "culture," means to till the soil in preparation for production of crops. ${ }^{4}$ Thus in the human context culture involves the cultivation of identities that are shared in common with a given community, whether they be material or emotional.

${ }^{1}$ Geert Hofstede, Culture's Consequences: Comparing Values, Behaviors, Institutions, and Organizations Across Nations, 2d ed. (London: Sage Publications Ltd., 2001), 9.

${ }^{2}$ Arthur F. Glasser, et al., Crucial Dimensions in World Evangelization (Pasadena, CA: William Carey Library, 1977), 45.

${ }^{3}$ Ibid., 10.

${ }^{4}$ The Concise Oxford Dictionary (1976), s.v. "Culture." 
A definition of culture carries with it a vast array of variants. Not only is there the material culture that includes objects and material reproductions, but there is also the symbolic definition that includes "valued styles, and ways of life, to manners and to rituals and custom with respect ... to birth, marriage and death, food and dress." $\mathrm{A}$ typical example would be in the variety of methods of greeting that is practiced throughout the world. They range from shaking hands in the cultures of England and Western Europe to sucking mouths in Panama. ${ }^{2}$ Cultural standard variations are found even within cultures and are not stagnant but are constantly being adjusted and defined. A missiological definition states that culture is "the activity through which women and men influence the environment in which they live with their physical and spiritual powers, at least partially change it, but at the same time develop themselves as individuals and members of a community. In this way men and women establish a suitable environment for themselves which is more than mere nature." ${ }^{33}$

There is a difficulty in giving an unbiased definition of religion because of the tendency to be influenced and conditioned by one's own religious outlook and worldview, and the influences of one's own environment. This is not helped by the fact that the etymology of "religion" also carries with it a certain level of uncertainty. There

${ }^{1}$ Steve Fenton, Ethnicity: Racism, Class and Culture (London: Macmillan Press Ltd., 1999), 8.

${ }^{2}$ Glasser, 46.

${ }^{3}$ Karl Muller, et al., eds., Dictionary of Mission: Theology, History, Perspectives (Maryknoll, NY: Orbis Books, 1987), 94. 
are suggestions that it is derived from the Latin religare, meaning, "to bind," or even the word relegere, meaning "to rehearse, or read over again."1

Two approaches in defining religion have to be used. The first is the substantive approach which emphasizes the content aspect of religion, i.e., religion as a belief system, and usually belief in spiritual beings and the supernatural. The second approach is called functionalist, and this deals with the difference that religion has on the lives of individuals and on society. ${ }^{2}$

Clouser discusses religion from the point of religious belief. He argues that "it is religious beliefs which prompt and guide the practices, rites, rituals, and attitudes we commonly call 'religious'."3 These beliefs are what color our thinking and influence the decisions we make in life. According to Beverley Clack and Brian Clack, this would be the functionalist approach to the definition.

Even though the definition of religion suggests an obligatory binding of the individual there is however an element of freedom that releases the adherent to choose whichever religion one feels most attracted to. Frederick J. Streng makes a valid point in stating that

We live in an age in which "religion" is objectified and studied as a human expression. We can do this at present because we admit that people in different cultures have different forms of religion, which we can compare without automatically feeling the need to defend one view against another. We no longer assume what the majority of men have assumed from earliest times until about two

${ }^{1}$ Beverley Clack and Brian R. Clack, The Philosophy of Religion, A Critical Introduction (Cambridge, UK: Polity Press, 2002), 4.

2Ibid., 2-4.

${ }^{3}$ Roy A. Clouser, The Myth of Religious Neutrality (London: University of Notre Dame Press, 1991), 9. 
centuries ago-that the traditional forms of religion provide the context in which man lives his life. We see religion rather as one authoritative element that contributes to self-awareness: One can either participate in the religious forms of one's culture or not. Likewise, today there is the attempt to redefine "religion," to make new assumptions about it's nature, and to recast it in different expressive forms.

Religion, then, is assumed to be one of several dimensions of life; and our age is extending and redefining the meaning of religious life.

Culture and religion, then, are closely akin and sometimes difficult to separate.

Karl Muller's definition of culture might suggest an inherent influence of religion in that culture is the activity that influences environments physically and spiritually. ${ }^{2}$ Each element—culture and religion—at times, influences the other. A correct understanding and appreciation of these elements however, equips one to be able to deal with the majority of the social issues that will be faced in society. If one takes time to understand someone else's culture and religion that person will inherit a greater degree of trust and will broaden one's circle of influence.

\section{Historical Overview of Culture and Religion}

\section{Cultural Overview}

The early settlers in what is now known as the British Isles were Celtic tribes from mainland Europe. Later Belgic tribes (known as Britons) became dominant until around 55 B.C. when the Romans began their military conquests. Anglo-Saxons later overran the Romans and set up settlements in England; however, Scotland, Wales, and Ireland were mainly Celtic. In 1066 the Normans from Normandy conquered and the

${ }^{1}$ Frederick J. Streng, Understanding Religious Man (Belmont, CA: Dickenson Publishing Co., 1969), 1.

${ }^{2}$ Muller, 94. 
eventual merger of the Anglo-Saxon and Normans formed the roots of what is today known as Great Britain. ${ }^{1}$ Over the centuries immigrant tribes continued to flow in from all over mainland Europe for all types of reasons, often to escape persecution and economic hardships. By the seventeenth century Britain was rapidly developing into an agricultural center and attracted traders from all over the world who eventually settled and contributed to making Britain the leading agricultural and commercial nation. By the late eighteenth and nineteenth centuries Britain was fast becoming an industrial nation and this continued to attract other immigrants such as Dutch Protestants, French Huguenots, Gypsies, Negroes and Jews. ${ }^{2}$ These all brought industrial skills to the nation, helping to lead Britain to the forefront of the industrial revolution and contributing greatly to the fabric of the evolving complexity of British identity and culture.

Britain is clearly not just one community; it is made up of many communities. Historically, there has never been a time when any one culture seemed to dominate. There has always been a mix of different cultures vying for recognition. The Celtic, the Anglo-Saxon, the African-Caribbean, the Asians, and the Jewish, to name but a few, all make up the very diverse and multicultural nature of British people. Today, the Scots, the Welsh, the Irish, and the English make up the major sections of the British community, but within these communities are other communities made up of immigrants from the wider British community, i.e., the former colonies. Each has its own internal development, issues, and conflicts that are continually being addressed. Over the years

${ }^{1}$ John Oakland, British Civilization: An Introduction (London: Routledge, 1989), ${ }^{2}$ Ibid., 27. 
these communities have merged and the issues have become complex. Parekh observes that, "Everyone belongs to more than one community; every community influences and has an impact on, and in turn is influenced by, others. None is self-sufficient, entire of itself. 'Britain' is the name of the space they all share. Some have far more weight and power than others, but no group, no community owns Britain. It is no one's sole possession."1

\section{Religious Overview}

Christian religion in Britain had its early beginnings during the Saxon period when the pagan tribes were converted to Christianity in A.D. 596-597 by St. Augustine who was sent by Pope Gregory. He was responsible for setting up Canterbury as an ecclesiastical center. ${ }^{2}$ The Celtics in Ireland received Christianity by St. Patrick in A.D. 432 and later spread it to Wales, Scotland, and the north of England. The church practiced Roman Catholic Christianity under the leadership of the Pope but this later led to rebellion in England, during the reign of King Henry VIII. In 1534 the king broke away from Rome after a threat of excommunication, and set himself up as head of the Church of England. Even after this separation from Rome he was not entirely sympathetic to the Protestant Reformation; in fact, he defended the papacy against Martin Luther and was rewarded, by the Pope, with the title Fidei Defensor (Defender of the Faith), a title that is still inscribed on the British coins. ${ }^{3}$

${ }^{1}$ Bhikhu Parekh, The Future of Multi-Ethnic Britain (London: Profile Books Ltd., 2000), 105.

${ }^{2}$ Oakland, 188.

${ }^{3}$ Ibid., 189. 
Many believed that the Church of England had not distanced itself far enough from Rome and did not continue to abandon many of the liturgies of Roman Catholic worship. Over the next century conflict increased between Catholics and Protestants that eventually led to the Civil War of 1642 to 1648 between Protestant Parliamentarians and Catholic Royalists. Minority religious groups, including Catholics, were persecuted in England and this led to further divisions in the Church of England and the creation of other "Nonconformist" groups. These groups became known as "Free Churches" and are made up of churches like the Methodist, Baptist, and Salvation Army. John Knox established the Church of Scotland in 1560 because he felt that the Church of England was still too closely akin to the Roman Catholic Church. His more radical move established elders and a democratic management structure. ${ }^{1}$

As a religious society the British Jewish community can trace its roots back to the Norman conquests when Jewish traders came as financiers and businessmen. Since the seventeenth century Jews have become more established and are said to be the second largest community in Europe. In the Jewish religious context in Britain there are two main groups which can be divided into the majority orthodox and the minority reform groups. Over the past forty years the community has declined and it is speculated that it is due to disenchantment, and perhaps secularization. ${ }^{2}$

Other non-Christian faiths consist of Buddhists, Sikhs, pagan, and Islam, to name but a few. Britain is not only a multi-cultural society; it has become, over the last forty years, a multi-faith community.

\footnotetext{
${ }^{1}$ Ibid., 194.

${ }^{2}$ Ibid., 197.
} 


\title{
Factors Influencing Cultural and Religious Changes
}

\author{
Immigration
}

Perhaps the number one factor influencing cultural change in the United Kingdom is that of immigration. It is the one factor that brings both blessings and curses to the host nation and the immigrant. It is a blessing because it gives opportunity for both to broaden their horizon and outlook on life but it is a curse because the jobs and housing of the host nationals seem threatened by this "invading force."

Colonialism had helped to shape the attitude of the British toward those immigrants from its former colonies, mainly Asia and the West Indies. "In the latter part of the $19^{\text {th }}$ century racial attitudes became notably harsher and these attitudes were closely associated with class, status and power. These were linked to class attitudes in that the portrayal of (particularly) black people as constitutionally weaker, as suited to menial laboring, and as potentially threatening and dangerous, were similar in tone to the views which the middle classes in Britain took to the urban proletarians. Irish workers in cities were viewed in much the same way."1

During the early part of the twentieth century Irish and Jewish immigrants were targets of hostility by the native Britons. Prior to 1914 and the First World War approximately one hundred and fifty thousand Jews migrated to Britain from Eastern Europe. $^{2}$ Concerning the Irish immigrants Fenton points out that, "Irish were treated with disdain and portrayed as 'animals' in a way that later non-white immigrants were to

${ }^{1}$ Fenton, 159.

${ }^{2}$ Andrew Godley, Jewish Immigrant Entrepreneurship in New York and London 1880-1914: Enterprise and Culture (Hampshire, UK: Palgrave, 2001), 20. 
experience and socialist writers Marx and Engels spoke of the Irish as part of the 'ethnic trash' of English cities. The Irish worked in service and laboring occupations, remitting money to their families and enduring the ethnic prejudice which, often as not, was antiCatholic prejudice."”

In the decades immediately after the Second World War Britain saw a major influx of war refugees and displaced immigrants from Poland, Italy, and other European countries. $^{2}$

Perhaps the most dramatic social change to take place in Britain during this period has been the setting up of ethnic minority communities throughout mainland Britain. These minorities arrived at a time when there was a great need for laborers in the failing industries. From about 1950 immigrants from the former colonies, Jamaica, Barbados, India, and Pakistan also began to arrive in Britain, by invitation, to join the labor force. ${ }^{3}$ Many West Indians found positions in transport, catering, the Health Service, and manual labor trades in London, Birmingham, and other large cities, whereas those from India, and Pakistan worked in the textile and iron industries of northern England. ${ }^{4}$

Table 5 illustrates the distribution of the main ethnic minority groups throughout mainland Britain. On arrival into the UK the main concentration areas were the industrial centers of England, whereas Wales and Scotland had relatively few immigrants.

${ }^{1}$ Fenton, 160.

${ }^{2}$ See Robert Winder, Bloody Foreigners: The Story of Immigration to Britain (London: Little, Brown, 2004), 236-51.

${ }^{3}$ Ibid., 161.

${ }^{4}$ Oakland, 30 . 
Despite the need for foreign labor, times of economic and political uncertainty created an air of suspicion toward the immigrant population. During the First and Second World Wars feelings of nationalism spread and this led to measures to curb the intake of foreign settlers and at the same time enact laws that protected settlers who were living in

Table 5. Residence of Minority Ethnic Population by English Regions, Wales, and Scotland (Thousands)

\begin{tabular}{|l|c|c|c|c|c|}
\hline Region/country & West Indian & Indian & Pakistani & Bangladeshi & $\begin{array}{c}\text { \% of Total } \\
\text { Population }\end{array}$ \\
Greater London & 288 & 333 & 72 & 51 & 16.6 \\
Rest of South East & 35 & 85 & 48 & 15 & 2.9 \\
West Midlands & 84 & 147 & 83 & 18 & 7.3 \\
North West & 25 & 57 & 75 & 5 & 3.6 \\
Yorkshire, & 24 & 44 & 87 & 6 & 4.2 \\
$\quad$ Humberside & 16 & 88 & 15 & 3 & \\
East Midlands & 14 & 11 & 1 & 1 & 1.0 \\
South West & 3 & 6 & 11 & - & 2.1 \\
East Anglia & 2 & 5 & 14 & 7 & 1.4 \\
North & 490.5 & 776.6 & 405.6 & 106.0 & 5.4 \\
England & 3.1 & 5.1 & 5.4 & 1.2 & 1.2 \\
Wales & 0.9 & 4.8 & 17.0 & 0.9 & 0.9 \\
Scotland & & & & & \\
\hline
\end{tabular}

Note: Figures for English regions have been rounded for "percent of Total Population" and include Arabs, African, "Mixed" and "other."

Source: Adapted from Ken Blakemore and Margaret Boneham, Age, Race and Ethnicity: A Comparative Approach (Buckingham, UK: Open University Press, 1994), 18.

Britain from racial discrimination. The $1971 \mathrm{Immigration}$ Act restricted the right to apply for British passports to those who were born in Britain or who had parents or grandparents born in Britain. This meant that automatic British citizenship was by birth only and so successive generations of immigrants who were British born would become 
British citizens. ${ }^{1}$ Between 1965 and 1976 three successive Race Relations Acts were passed which made it unlawful to discriminate against anyone on the grounds of race, national origin, or ethnicity. ${ }^{2}$ Many of these race relations and immigration laws have fueled much criticism from the ethnic minority community in Britain because it was felt that the British government was not appreciative of the advantages of a truly multicultural society. In addressing the subject of multiculturalism Parekh suggests, "The diversity of its population gives Britain important opportunities in the global markets that now shape the world economy. Britain's potential to become a community of communities is not something to shy away from-its people should celebrate it. In the world developing now, it is perhaps the country's biggest single national advantage."”

Another phenomenon that has affected the British attitude to foreigners and the effect that they have on the British culture is that of the influx of asylum seekers, not only into Britain itself but also into the continent of Europe. Prior to the 1980s the government and people in general, were very sympathetic toward asylum seekers. They were seen as heroes who were escaping persecution. Since the 1980 s perceptions have changed due to the fact that many have been accused of falsifying their claims to asylum. ${ }^{4}$ The British government imposed visa requirements on countries from where large numbers of immigrants were coming and this in turn encouraged illegal trafficking

${ }^{1}$ Keith Jenkins, The Closed Door: A Christian's Critique of Britain's Immigration Policies (London: British Council of Churches, 1984), 7.

${ }^{2}$ Oakland, 29.

${ }^{3}$ Parekh, 10.

${ }^{4}$ Tbid., 213. 
of people because visas were not issued for asylum seekers. However, Article 3 of the 1951 European Convention on Human Rights places a ban on countries returning asylum seekers to countries where their lives might be endangered. As a result the general British public has accused the government of being too soft in allowing the country to be “over-run" by asylum seekers. ${ }^{1}$ One report suggests that, "Three asylum acts, 1993, 1996 and 1999, were passed to reduce the level of applications which had reached 44,840 in 1991. Yet between 1992 and 2000 the mean yearly increase in asylum applications was nearly 13 per cent. In 2000 , the number of applications was $80,315,13$ per cent more than in 1999."2 The figures for 2002 indicate that there was another record high of 85,865 , a seven percent increase on the previous high of $2000 .^{3}$

As a result of this general attitude these new immigrants have been mistreated in communities, prisons, and also in schools by those who think they should not be here. ${ }^{4}$

Traditionally the British, as with most other nations, are very nationalistic. They are proud of their country and their language. Winston Churchill once referred to the English-speaking peoples as "the bearers of civilization." This, suggests Fenton, implies that those who are not English speaking are less or not civilized. ${ }^{6}$ Since the 1950 s the

${ }^{1}$ Paul Eastham, Daily Mail, 27 January 2003.

${ }^{2}$ Jo Butler, Daily Mail, 25 February 2003.

${ }^{3}$ Nick Spencer, Asylum and Immigration: A Christian Perspective on a Polarised Debate (Buckinghamshire, UK: Paternoster Press, 2004), 17.

${ }^{4}$ Parekh, 216.

${ }^{5}$ Fenton, 204.

${ }^{6}$ Ibid. 
preservation of the British culture has been a major point of discussion and debate by many political activists. In the 1960s Enoch Powell, a member of Parliament was at the forefront of guarding England from being polluted by other cultures. In his famous "Rivers of Blood" speech ${ }^{1}$ he warned of Britain becoming dominated by immigrants from the Commonwealth. Margaret Thatcher echoed similar nationalistic sentiments in the 1979 General Election campaign when she referred to the fear of the British being "swamped" by the introduction of a "non-English" culture. This was further played out in Britain's involvement in the European Union debates and the losing of British sovereignty and British identity. ${ }^{2}$

Nevertheless, it is very evident that the growth of the immigrant population has brought no lasting negative changes to the British economy or culture. To the contrary, the changes have been very positive and have enriched the culture of Britain. This enrichment is seen in the variety of international and continental foods and restaurants, styles of dress, and festivals that are shared by all sectors of society. The music and drama of immigrant artists are all clearly seen as one visits the theatres and music venues throughout the country.

\section{Globalization}

Another factor that has influenced change in the British culture is globalization. Immigration and the temporary movement of people and cultures also influence this phenomenon across the world. Malcolm Waters' definition suggests that globalization is

\footnotetext{
${ }^{1}$ The National Front, "The Prophecies of Enoch Powell," http:// www.natfront. com/powell.html (23 November 2003).

${ }^{2}$ Fenton, 204.
} 
"a social process in which the constraints of geography on economic, political, social and cultural arrangements recede, in which people become increasingly aware that they are receding and in which people act accordingly."1 He suggests that these constraints are manifested in four main areas, namely, economic, political, social, and cultural. These are universal concerns and therefore have effected cultural change in Britain.

In Britain globalization is viewed with mixed feelings on the part of the general public. On the one hand consumers and business professionals welcome it because it means more variety in the market places. "Supporters of globalization say that it has promoted information exchange, led to a greater understanding of other cultures and allowed democracy to triumph over autocracy."2 A 1999 poll conducted by a U.S. Information Agency showed that the majority of the British public (57 percent) prefers a free trade economy that would promote growth and low prices. ${ }^{3}$

On the other hand protesters complain that the Western countries are exploiting the labor markets of the developing world. They claim that globalization has increased feelings of insecurity in the workplace due to the fact that the job market has been opened up to those in the developing world because many companies are relocating their businesses overseas in countries where the cost of labor is cheaper. ${ }^{4}$ According to the

${ }^{1}$ Malcolm Waters, Globalization, 2d ed. (London: Routledge, 1995), 5.

${ }^{2}$ See BBC News, E-CYCLODIA, "Globalisation: What on Earth is it about?" http://news.bbc.co.uk/1/hi/special_report/1999/02/99/e-cyclopedia/71 1906.stm (7 October 2003).

${ }^{3}$ Steven Kull, "Culture Wars? How Americans and Europeans View Globalization," Brookings Review 19, no. 4 (Fall 2001): 18. Cited in http://www .questia.com/PM.qst?action=print\&docId=5000913066jsessionid=Cn01 (9 June 2005).

${ }^{4} \mathrm{BBC}$ News, E-CYCLODIA. 
Foreign Policy magazine, of all the industrialized nations, Britain has an overall ranking of ninth in their globalization index. ${ }^{1}$ This means that Britain competes well with the global economy and the changes necessary for the integration of foreign investors into the British markets are encouraging.

Globalization has also influenced Britain's response to the European Union. It was in the year 1973 that Britain was led into what was then known as the "Common Market" or the European Economic Community (EEC). It was established in 1957 by the Treaty of Rome to facilitate five main objectives, namely, "(1) the removal of barriers to trade among the member nations; (2) the establishment of a single commercial policy toward non member countries; (3) the eventual coordination of transportation systems, agricultural policies, and general economic policies; (4) the removal of private and public measures restricting free competition; and (5) the assurance of the mobility of labour, capital, and entrepreneurship." ${ }^{, 2}$ Now citizens of member states are able to travel freely with a European Union passport across all borders, whether it is for business or pleasure. This has produced openness and a general acceptance of people with regional and foreign accents in the work place. The increase of foreign accents and languages has meant that libraries and other public services have had to provide services for those who are not conversant with the native English language and it has exposed the English speaking public to a multiplicity of foreign language literature.

\footnotetext{
${ }^{1}$ See http://www.foreignpolicy.com/issues_janfeb_2003/countrydetail.php (7 October 2003).

${ }^{2}$ The New Encyclopaedia Britannica, $15^{\text {th }}$ ed., s.v. "European Economic Community."
} 
Globalization has created opportunities for the sharing, and appreciation of cultural differences, especially in the area of the arts. The government's "Department for Culture, Media and Sport" was set up to, among other things, promote the quality of the cultural life of Britain. ${ }^{1}$ In its "International Policy Document" it is stated that it is to forge close links with the European Union and the international community. ${ }^{2}$ Culture, sports, and the arts have really become globalized in that the sharing of talent and expertise across national boundaries has become common place. For example, managers of national soccer (football) teams no longer belong to the host nation; it is an accepted change to have sports coaches competing against their own national team.

\section{Religions}

Religious changes in Britain have taken place mainly over the last twenty years. These changes are noticeable in the mainstream religions of Christianity, Islam, Judaism, and other faiths that have started in Britain within the last century, mainly due to importation of not only people but also religious faiths. These changes have been influenced by factors such as the declining influence of the Church of England, the state church as seen in the community on a whole, the impact of pluralism as a direct result of increased tolerance, and the development of a multicultural Britain, and the impact that immigration has had on the rise of other faith groups-Islam in particular.

The term secular society has often been used as a general description of Western Europeans, implying that they have a limited understanding of religious themes and do

\footnotetext{
'See UK Government, Department of Culture, Media and Sport, http://www .culture.gov.uk/about_dcms (15 October 2003).

${ }^{2}$ Ibid.
} 
not consider religion to be of any importance to their lives-religion and God are relegated to the "back burner." However, it is perhaps more appropriate to describe Western Europeans and the British in particular as unchurched rather than secular. "Unchurched" implies that they have a religious belief but choose to keep it private and concealed and do not see the need to identify with any particular denomination or faith. ${ }^{2}$ This description applies more so to the indigenous population of Britain and Europe as opposed to those who are classed as immigrants. Despite this, statistics do show that the majority of churchgoers and regular attendees of worship services on Sundays are of the white population, with 88.1 percent attendance. ${ }^{3}$ Grace Davie points out that the British, along with most of western Europe, have a nominal claim to church membership. Since the end of the Second World War church attendance among the indigenous population has declined but very few would disclaim a belief in God. In fact she claims that "relatively few British people have opted out of religion all together: out and out atheists are rare." "The arrival of significant numbers of black Christians, Muslims, Sikhs and Hindus has, nonetheless, brought a new dimension to post-war British religion. The Christian churches were offered an unexpected opportunity for growth-never mind renewal-as black (usually Afro-Caribbean) Christians arrived in the major cities. That 1994), 2.

${ }^{1}$ Grace Davie, Religion in Britain Since 1945 (Oxford, UK: Blackwell Publishing,

${ }^{2}$ Ibid., 12.

${ }^{3}$ Peter Brierley, ed., UK Christian Handbook Religious Trends 3 (London: Christian Research, 2001), 2-5.

${ }^{4}$ Davie, 2. 
they failed to take this opportunity is one of the saddest indictments of mainline Christianity in this period."1

\section{Declining Influence of the Church of England}

It can reasonably be claimed that the changes that have taken place in British religious society is partly due to the declining influence that the Church of England has in society. A general perusal of the religious commentary in the various British newspapers of recent times reveals that public attitudes concerning the church have been mixed and varied and this has left the church not really knowing what her true role is in society. Oakland makes the comment that, "In recent years, the Church of England seems to have been more willing to enter arguments about social and political problems in contemporary Britain. It has tended to shy away from such issues in the past, and has been described as 'the Tory Party at prayer' because of its safe, somewhat establishment image. It is still widely felt that the church, like the monarchy, should not involve itself in such questions. But some critics argue that the church must radically change its attitude, organisation, and values if it is to continue as a vital force in British life."2

Coming from a tradition where the Anglican Church in Britain was the central hub that turned society and whose influence was felt from politics to education, it is somewhat sad to hear the criticisms that have been levied against the established state church concerning its declining role. According to Sean Poulter, "Shopping has taken

\footnotetext{
${ }^{1}$ Ibid., 25-26.

${ }^{2}$ Oakland, 193.
} 
over from religion for the average British family. Lives which once revolved around church and its peripheral activities now center on the local supermarket."

Public opinion seems to be the catalyst for the church's policy on worship and lifestyle. Davie points out that during the decade of the 1960s, in an attempt to appear relevant to society, the church adopted some of the strategies, ideas, and expressions of the secular world. She suggests that, "The desire to be modern, to be in rather than out of step with the world, lay behind a whole series of 'reforms' within the Anglican and free churches: intellectually, in the theological and moral debates of the period...; organizationally in the rearrangement of parishes, priests and people . . ; liturgically, in the 'modernization' of scripture and worship ... ; and ecumenically in a variety of endeavors toward greater ecclesiastical collaboration."

Over the past decade alone the church has been dogged by controversies over its attitude to women's ordination and its acceptance of homosexual priests. The issue of women's ordination was responsible for major dissent in the Anglican Communion and as a result of the voted acceptance of ordination many loyal and traditional Anglicans defected to the Roman Catholic faith. The controversy however, appears to have been short-lived because women clergy are now engaged in their ministry almost unnoticed and enjoying relative success compared with their male counterparts.

A Christian research survey was recently conducted (in 2002) to show Anglican feelings toward certain issues including who in the Anglican Church should be ordained.

\footnotetext{
${ }^{1}$ Sean Poulter, Daily Mail, 29 January 2003.

${ }^{2}$ Davie, 34.
} 
Of an average of 1,705 clergy and 1,884 laity respondents the results are shown in table 6.

It would appear that the Anglican laity is less tolerant in having ordained divorced and remarried and homosexual clergy serve in the Anglican Church than are the Anglican clergy generally.

The ordination of homosexuals to the priesthood appears to be a more controversial subject and one that may create greater rifts in the Anglican Church. On the one hand the church is being accused of being too intolerant and out of touch with society for not recognizing the call of homosexuals to the priesthood, and on the other hand it is being accused of compromising its principles by not being true to the explicit teachings

Table 6. Anglican Opinion on Ordination

\begin{tabular}{|l|c|c|c|c|c|c|}
\hline Statement & & AS (\%) & A (\%) & NO (\%) & D (\%) & DS (\%) \\
\hline Divorced people should & $\mathrm{C}$ & 25 & 51 & 10 & 10 & 4 \\
be ordained as priests & $\mathrm{L}$ & 14 & 45 & 16 & 17 & 8 \\
\hline & $\mathrm{C}$ & 18 & 34 & 12 & 20 & 16 \\
Divorced and re-married & $\mathrm{L}$ & 10 & 29 & 18 & 25 & 18 \\
\hline priests to be consecrated Bishops & $\mathrm{C}$ & 21 & 46 & 12 & 14 & 7 \\
Divorced and remarried & $\mathrm{L}$ & 13 & 42 & 15 & 20 & 10 \\
people to be ordained as priests & $\mathrm{C}$ & 13 & 18 & 11 & 24 & 34 \\
\hline & $\mathrm{L}$ & 6 & 13 & 12 & 26 & 43 \\
\hline
\end{tabular}

C: Clergy, L: Laity, AS: Agree Strongly, A: Agree, NO: No Opinion, D: Disagree, DS: Disagree Strongly.

Source: Peter Brierley, UK Christian Handbook Religious Trends 4 2003/2004 (London: Christian Research, 2003) 5-7. 
of the Christian Bible. Reports suggest ${ }^{1}$ that two-thirds of clergy are opposed to ordination of homosexuals, however, this is seen by the Lesbian and Gay Christian Movement as being a positive result because they say, "One-third in favour is within sight of half. Since some theological colleges have a large number of gay students training for ordination, it can't be long before a majority in the church supports our cause." Pressure on the church to conform to society's norms are growing in light of the fact that the Anglican church internationally appears to be taking the lead in this particular issue and the Church of England may be forced to comply with popular opinion. The Archbishop of Canterbury, Rowan Williams, in addressing the subject of ordination of gay clergy stated that there was a risk that this issue might "tear the fabric of the church," and jeopardize the future of the Anglican Communion. ${ }^{3}$

Since 1534 there has been a gulf between the Church of England and the Roman Catholic Church as a result of Henry VIII declaring himself to be head of the church in England. However, in recent times there has been a gradual "mending of the breach" between the Anglican Church and the Roman Catholic Church. In 1982 for the first time in her history, Britain was visited by the Pope, and within seven years the Archbishop of Canterbury, Robert Runcie, after a visit to the Vatican to discuss the fragile relations between the two communions, ${ }^{4}$ and being the first Archbishop of Canterbury since the

\footnotetext{
${ }^{1}$ Ruth Gledhill, The Times, 6 September 2002.

${ }^{2}$ Ibid.

${ }^{3}$ Pat Hurst, The Independent, 17 October 2003.

${ }^{4}$ Clifford Longley, The Times, 29 September 1989.
} 
Reformation to be present at a papal mass, announced that the Pope should be recognized as a religious leader of a united church. Reports state that

Dr. Runcie's call to Christians to recognize the pope as their 'universal leader' split the Anglican Church. ... . Dr. John Scott, the queen's chaplain and president of the Evangelical Fellowship of the Anglican Communion, welcomed the idea of a universal primacy, but it depended on what form it would take.

"It would not affect the position of the queen at all. On this ground she would remain head of the Church."

He added: "I can understand that if people are thinking of the kind of jurisdiction which the Pope exercises now, that would be incompatible with the queen's position.

But if the Church of England is allowed to retain a real autonomy, as Dr. Runcie said, it would not be incompatible."

On 13 January 2002, Cardinal Cormac Murphy-O’Connor, Roman Catholic Archbishop of Westminster in London, was invited by Queen Elizabeth II to speak at the Church of St. Mary Magdalene on her estate in Sandringham, Norfolk. It was the first time since 1688 that a Roman Catholic had, by invitation, addressed the monarchy in England and Wales. The intention was to forge greater "unity and friendship" with the Roman Catholic Church, and the occasion was described by the Cardinal as a "very significant event."2

These and other factors have no doubt led to a move to review the connection between the Church of England and the state. It is felt that many of the Acts of Parliament concerning religion are biased toward the Church of England and there is need to share the privileges with all other faith groups. In the discussion of the reform of the House of Lords a report to the House of Parliament by the Right Honorable Lord Wakeham, Chair of the Royal Commission on the Reform of the House of Lords,

\footnotetext{
${ }^{1}$ Ibid., 2 October 1989.

${ }^{2}$ See Jonathan Petre, The Telegraph, 13 January, 2002.
} 
suggests that there is need for reform because the question arises as to whether the Church of England can adequately represent all faiths in the second chamber. The commission identified that, "The Church of England bishops, although they claim to speak in the House of Lords 'not just for the Church of England but for its partners in other Christian churches, and for people of other faiths and none,' are not representative of the broad spectrum of religious opinion in the United Kingdom. By definition, they represent only the Anglican Church, in one part of the United Kingdom. That is the foundation of our majority view that it would be desirable to broaden the basis of explicit religious representation in the second chamber."1

If this discussion is taken to its most logical conclusion and the recommendations followed, then the Church of England will soon fail to be the representative voice of Christianity in the political arena and room will have to be made for the ever growing number of those of non-Christian faiths.

\section{Impact of Pluralism}

In his discussion on the subject of pluralism Hans Gensichen suggests that "respect for and co-operation with others can disclose commonalities among people of different faiths. What is held in common serves as a basis for understanding what is different and vice versa. The freedom for worship which one group expects must be granted to others. Thus it is one of the outstanding ecumenical tasks to articulate a

\footnotetext{
${ }^{1}$ Rt. Hon. Lord Wakeham, " $A$ House for the Future: Royal Commission on the Reform of the House of Lords, " 20 January 2000. http://www.archive.official-documents .co.uk (3 November 2003).
} 
Christian theology of religion which can promote and under gird a responsible dialogue with people of different faiths."

Even though religious tolerance is the area in which pluralism may be most noticed, it is becoming increasingly clear that Britain must become more inclusive in its approach to religion and religious ceremonies, especially in matters relating to the crown and the coronation. Traditionally, the Church of England has played the major role in the coronation ceremony, seeing that the head of state is also head of the church and carries the title, "Defender of the Faith," namely, the Christian faith. However, it is reported that the Prince of Wales, heir to the throne of England, has suggested that he be acknowledged as "defender of faiths," in order to recognize the diversity of religious faiths that compose the British population. ${ }^{2}$

This move would strongly indicate the vast strides that society has taken toward a pluralistic society. The composer James Macmillan, in his lecture at the Edinburgh Festival in August 1999 outlined his dream of "a genuinely pluralistic democracy where differences are not just recognized and respected but celebrated, nurtured and absorbed for the greater good." It would be considered politically incorrect for one to ignore the existence of other religious faiths coexisting with Christianity. It would also be correct to acknowledge their contributions to the overall religious fabric of society.

${ }^{1}$ Dictionary of the Ecumenical Movement, (1991), s.v. "Pluralism."

${ }^{2}$ Michael White, The Guardian, 11 April 2000.

${ }^{3}$ Parekh, 242. 


\section{Impact of Islam}

This acknowledgement of a pluralistic society forces one to consider the impact that world religions, especially Islam, has had on the religious milieu of British society. The rise of Islam has been a major cause of concern for many in Britain, especially with the rise of terrorist activity and increased incidents of suicide bombings by Muslim fundamentalists. Despite this recent concern, Britain has had a long history with Muslims, dating back to the reign of Queen Elizabeth I in 1588, when she formed an alliance with Murad III of the Ottoman Empire against Spain. ${ }^{1}$ Relations continued into the 1600 s and to the establishment of the merchant shipping company known as the East India Company. Men from India, known as lascars were recruited as merchant sailors and eventually set up settlements in London and other British shipping ports. After the opening of the Sueż Canal in 1869 others were recruited from Yemen. Before the start of the First World War Muslim communities were already set up in London, Liverpool, and Woking. "In 1924 it was reckoned that thirty regularly attended prayers at the Woking mosque, [and] that there were a thousand British Muslims scattered about the country and 10,000 Muslims from overseas." ${ }^{2}$ Further tolerance toward Islam as a religion was shown when in 1944 King George VI donated land in Regent's Park for the erection of the Central Mosque in exchange for a similar gesture in Cairo for an Anglican Cathedral. The mosque was opened in 1977. Since the donation of the land the Muslim presence

\footnotetext{
${ }^{1}$ Philip Lewis, Islamic Britain: Religion, Politics and Identity among British Muslims (London: I. B. Tauris and Co., 2002), 11.

${ }^{2}$ Ibid., 13.
} 
had so grown that the number of registered mosques had multiplied from 18 in 1966, to 136 in 1977 , to 338 in $1985 .{ }^{1}$

The vast majority of Muslims in Britain come from the southern Asian countries of Bangladesh, India, and Pakistan, with an increasing minority coming from the Arab world: Turkey, West Africa, and Malaysia. It is projected that within a relatively short period of time, if present trends continue, the Bangladeshi and Pakistani Muslim communities will actually double in population size, thus making south Asians the dominant Muslim group. ${ }^{2}$ Philip Lewis points out that this dominance has strengthened the Muslim community to the extent that it is able to "generate and sustain a separate institutional and economic infrastructure which embodies and perpetuates religious and cultural norms. The huge investment in and proliferation of mosques is one dramatic indication of both a Muslim commitment to stay in Britain and a determination to pass on to their children their religious and cultural values."3

The proliferation of mosques in Britain suggests that the majority of the British population is forced to acknowledge that Islam and Christianity must inevitably demonstrate mutual respect for one another. If present trends continue, it will soon be necessary to teach both Islam and Christianity as part of the official religious education in British schools. These changes have been rapid ones that have caught British Christianity

${ }^{1}$ Ibid., 14.

${ }^{2}$ Tbid., 15 .

${ }^{3}$ Ibid., 19. 
off guard and perhaps the only way to counteract it is to present Christianity as a viable alternative to Islam.

\section{Postmodernism}

The term "postmodern" is one that has gradually become part of the regular English vocabulary over the past three decades. Historically, it is a term that has been mostly used in the areas of the arts, theatre, and architecture; however, the attempts to incorporate it into the cultural and religious arenas have created some controversy. Some writers, claiming that it has influenced society, have tried to present an understanding of postmodernism, and in this section an attempt will be made to present some of their thoughts.

A true and concise definition of the term has not been proven to be very easy among scholars and philosophers but nevertheless one that needs to be defined for the purposes of this paper. I would like to start with Stanley Grenz' attempted definition and explanation. He suggests that "postmodernism signifies the quest to move beyond modernism. Specifically, it involves a rejection of the modern mind-set, but launched under the conditions of modernity. Therefore, to understand postmodern thinking we must view it in the context of the modern world that gave it birth and against which it is reacting."l.

So, according to Grenz, a correct understanding of postmodernism is possible only as one begins to appreciate modernism, the precursor of postmodernism.

\footnotetext{
${ }^{1}$ Stanley J. Grenz, A Primer on Postmodernism (Grand Rapids, MI: Wm. B. Eerdmans Publishing Co., 1996), 2.
} 
Modernism is characterized in mankind's quest for knowledge and to understand the world in which we lived. From the time of the fourth century A.D. until the Reformation period of the sixteenth century intellectual thought was dominated by the church and theology. All knowledge was assessed and certified by the teachings of Christianity, and anyone who dared to contradict or refute the revealed truth of the church ran the risk of ostracism.

However, the period of the Enlightenment brought this to an end. People were now courageous enough to challenge the authority of the church and its claim to be the repository of knowledge. Stanley Grenz, in commenting on the sixteenth century philosopher, Francis Bacon, quoted him as saying that "knowledge is power;", that power was demonstrated especially in the areas of science and philosophy and is a product of the Renaissance which in turn led to the period of the Enlightenment. The Enlightenment period was one of liberty in that it released mankind to acknowledge the power of reason over ignorance, order over disorder, and science over superstition. ${ }^{2}$ Bacon, in agreement with other European philosophers of his time, shared the conviction that "the human mind is fitted for knowledge of nature and must derive it from observation, not from abstract thinking." 3 He refuted sharply the thinking that knowledge should be "accepted

${ }^{1}$ Ibid., 59.

${ }^{2}$ Barry Burke, "Post-modernism and Post-modernity," http:// www.infed.org/ biblio/b-postmd.htm (23 November 2003).

${ }^{3}$ Encyclopaedia Britannica, 1987 ed., s.v. "Francis Bacon." 
with great limitation and caution." He claimed that it is not the quantity of knowledge but the quality that is of danger to the mind of man. ${ }^{1}$

Whereas the pre-enlightenment philosophy suggested "belief in order to understand," the modern thought stated that we "believe only what we understand."2 Whereas, the pre-enlightenment period placed God in the center of all theories and philosophies, the Enlightenment period placed man in the center. The focus on the acquiring of knowledge broadened man's understanding of science and mathematical logic, and mankind no longer saw himself as the crowning act of creation but rather as a minute particle in a vast cosmos.

The modern, post-Enlightenment mind assumes that knowledge is certain, objective, and good. It presupposes that the rational, dispassionate self can obtain such knowledge. It presupposes that the knowing self peers at the mechanistic world as a neutral observer armed with the scientific method. The modern knower engages in the knowing process believing that knowledge inevitably leads to progress and that science coupled with education will free humankind from our vulnerability to nature and all forms of social bondage. ...

... From Francis Bacon to the present, the goal of the human intellectual quest has been to unlock the secrets of the universe in order to master nature for human benefit and to create a better world. ${ }^{3}$

Postmodernism sets out to contradict, refute, and reject the ideals and philosophies of the modern era. According to postmodern philosophy people are not necessarily the central focus, nor is the acquiring of knowledge the focal point of the average person's existence. All knowledge and truth are subject to interpretation and 1962), 4-6.

${ }^{1}$ Francis Bacon, The Advancement of Learning (London: Everyman's Library,

${ }^{2}$ Grenz, 62.

${ }^{3}$ Ibid., 81 . 
dogmatically held viewpoints have become socially unacceptable. Order and uniformity have taken on new meanings and are no longer the ideals that society strives to achieve.

\section{Cultural Implications}

The art critic Suzy Gablik, speaking in Los Angeles in 1989, spoke about the "multidimensional and slippery space of Postmodernism [where] anything goes with anything, like a game without rules. Floating images ... maintain no relationship with anything at all, and meaning becomes detachable like the keys on a key ring. Dissociated and decontextualized, they slide past one another failing to link up into a coherent sequence. Their fluctuating but not reciprocal interactions are unable to fix meaning.",1 British architecture has reflected the views of Gablik in many instances. The development of the London Docklands in the east end of London is an example of architects being given the freedom to be as creative as their imaginations will allow. New building designs are a striking contrast to what had become the norm in that part of London.

Similarly, postmodernism can be seen reflected in the advertising and the music industries. The transition that took place during the decade of the 1980 s with Punk Rock, for example, reflected the daring spirit that typifies the postmodern mentality. The harmonies of the sixties and seventies were no longer there and this discord was reflected not only in the music but also in dress and adornment. The influence of the media cannot be underestimated; in fact, the media is an integral part of the transition from modernism

${ }^{1}$ Quoted in Alex Callinicos, Against Postmodernism: A Marxist Critique (Cambridge, UK: Polity Press, 1989), 12. 
to postmodernism. The rapid paces at which the media images are bombarding society probably reflect the pace at which society is becoming postmodern.

Culturally, postmodern Britain is somewhat undefined. The lines of demarcation are unclear compared with previous eras. This is partly due to the fact that society is still struggling with modernists who are intent on holding on to modernism and postmodernists who are pushing for change. This struggle between two generations has created vagueness when it comes to a clear definition of postmodernism. Perhaps the vagueness has enabled an emphasis on flexibility and diversity. This has allowed society to unashamedly celebrate differences and to discourage any attempt to explicate social phenomena. Zygmunt Bauman suggests that postmodernism "does not seek to substitute one truth for another, one life ideal for another.... It braces itself for a life without truths, standards and ideals."1 One cannot help but wonder if this unwillingness or inability to set truths, standards, and ideals has given license to religious fundamentalists who are reacting to a world that, in their eyes, is digressing from the fundamental truths that are necessary for an orderly world.

Postmodernism has created a culture of tolerance that allows for socially constructed identities to coexist and at the same time campaign for individual rights. In recent years the stigma that was attached to homosexuality has rapidly eroded and gays and lesbians no longer feel threatened to make their sexuality known. The same goes for skin color and regional accents. These differences are now not only accepted but also ix.

${ }^{1}$ Zygmunt Bauman, Intimations of Postmodernity (London: Routledge, 1992), vii, 
freely celebrated and there is a drive to acknowledge the contributions that all cultures have made and are making to the overall fabric of society.

\section{Religious Implications}

Of all the ideologies that have been impacted by postmodernism religion perhaps faces the greatest challenge of them all. The challenge is great because religion has traditionally aimed to convince society to accept the truths as interpreted by their particular group. Competition was rife between opposing religions but postmodernism has created a new tolerance that demands that one does not question the propositions of another religious point of view. There is growing toleration for religions and faiths that do not have a voice, and the general view is that everyone is of equal value and should be heard. Intolerance is shown only to those groups who appear to be fundamentalist in their viewpoints and are themselves, intolerant toward others. "Today, when people refer to 'fundamentalists' they no longer mean just religious extremists like the Shiites waging holy war against the West. Today, fundamentalism may refer to anyone who claims to know truth or who charges another religion with falsehood." To take this a step further, any Christian group who lays claim to having an authority on Scripture and biblical interpretation would also be considered to be fundamentalist in the eyes of the postmodern observer.

Postmodern tolerance is reflected in the religious philosphies of the East. Postmodernism is a rejection of the Age of Reason and likewise many eastern religions

' See Jim Leffel and Dennis McCullum, Postmodernism and You: Religion, cited on http://www.xenos.org/ministries/crossroads/dotrel.htm (23 November 2003). 
reject the notion that the reality of the world and the universe can be understood objectively. Both Hinduism and Sikhism teach that the material world is maya, an illusion; reality is not what it appears to be. "The world may seem to be vividly real but, from the standpoint of the higher level of truth, it is then seen to be illusory."1

Closely akin to the eastern religious philosophies is the philosophy of the New Age movement. A single clear definition of New Age philosophy is hard to come by. New Age thinking suggests not only that reality is not what it seems but also that truth is not something that is discovered but rather it begins with self as the source and therefore its interpretation is by intuition. "It is, probably, not even objective; it is whatever plucks the answering chord in ourselves." It is concerned with so many varied philosophies that even its adherents join for different reasons. "New Age can include, but is not confined to, past life regression, channeling of spirits of the dead, crystals, theosophy, Eastern religions and yoga (both thousands of years old), the search for self, meditation, autogenic training, music, Est, dream work. It refers to thinkers who speak for the New Age, to philosophers who posit an unseen movement, a conspiracy, an emergence of new life and creativity in several areas of scientific and daily life. It is concerned for ecology, political justice, the end of hunger."3

${ }^{1}$ Raymond Hammer, "Approaches to Truth: The Great Interpreters," in The World Religions (Hertfordshire, UK: Lion Publishing Plc., 1988), 183.

${ }^{2}$ Michael Perry, Gods Within: A Critical Guide to the New Age (London: SPCK, 1992), 21.

${ }^{3}$ Duncan S. Ferguson, ed., New Age Spirituality: An Assessment (Louisville, KY: Westminster John Knox Press, 1993), 4. 
Another indication that postmodernism has an impact on religion in Britain is the estimated steady rise in adherents to non-Christian religions since 1990. Figure 1 illustrates this increase. This indicates that the British population is more tolerant and accepting of beliefs other than traditional Christianity. The mere fact that they operate in Britain and the numbers increase steadily might also indicate that not only are these religions made up of immigrants but they offer an alternative to the general indigenous British population. The choices that one would expect in the high street supermarket are the same that one should expect from the various religions on offer.

In June 2000 the British Broadcasting Corporation (BBC) broadcaster Michael Buerk wrote and presented a television program called "Soul of Britain" in which he explored the religious beliefs of the British public. The BBC commissioned an extensive survey for the purposes of the program ${ }^{1}$ and discovered that since 1937, when the membership of the Christian church in Britain was 78 percent, the Christian church membership has fallen to just 42 percent. In addition to this the survey showed that whereas only 9 percent of the population believes that their particular faith is the best path to God, 32 percent think that all religions are of equal value. Many who continued to adhere to traditional Christian beliefs also merged this with belief in reincarnation and other eastern religious teachings.

${ }^{1}$ All statistics in the following discussion are taken from http://www.focus. org.uk/soul and http://www.thetablet.co.uk. 


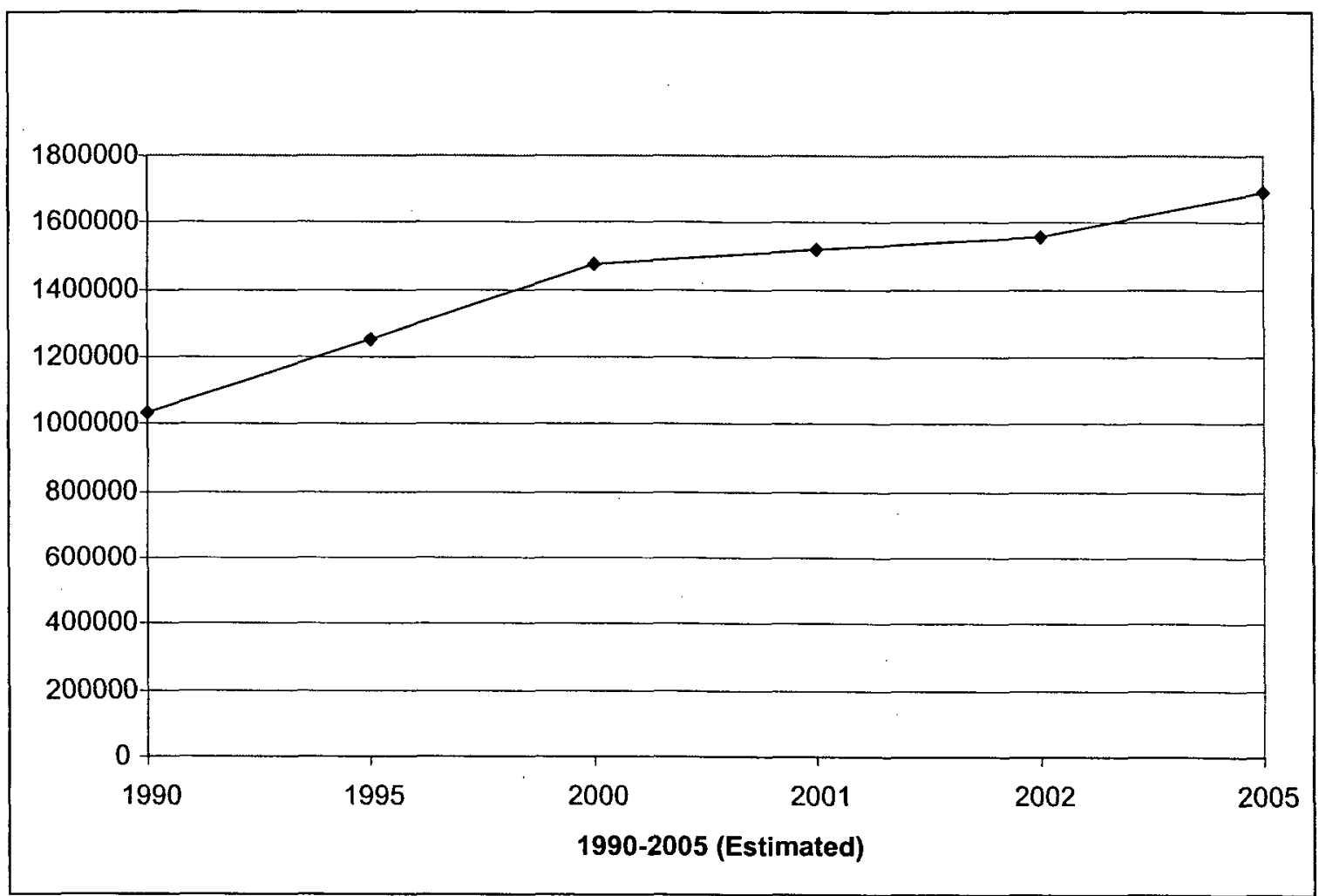

Figure 1. Membership of Non-Christian Religions in UK. Taken from Peter Brierley, ed., UK Christian Handbook Religious Trends 4 (London: Christian Research, 2003), 10.

Another significant discovery from the survey is that belief in God had declined to just 27 percent. This however, did not mean that the nation had become more atheistic but it revealed that more people had classified themselves as being "spiritual," as opposed to being religious; and belief in having a soul superceding that of a belief in a personal God. The increase in spirituality has created an appetite for prayer even in those who do not consider themselves to be religious and as many as 40 percent claim that they have received help in answer to prayer.

One confirmation that came from the survey is that people on a whole have lost confidence in institutions, be it the police, parliament, major companies, and even the institutionalized church. People do not believe that scientists are able to supply the 
answers to the social and economic problems of life and neither has the church been able to do so.

Religion has been seen by regular churchgoers to be only able to provide spiritual guidance and moral teachings for children; however, the general public believes that religion is increasingly unable to influence what is judged to be right and wrong in society. This has resulted, according to the survey, in people looking within themselves instead of to God for direction. The survey revealed that whereas in 1990,35 percent of the population believed that there were clear guidelines about what was right and wrong, presently, 75 percent think that there can never be clear guidelines because all is dependant on circumstances.

\section{Effects of Cultural/Social Changes on the Seventh-day Adventist Church}

The Seventh-day Adventist church in Britain as an institution has not escaped the effects that cultural and social changes have had on society. By and large, the effects on society have been reflected in the church because it has always been a reflection of society. It reflects society because the church has to do with people and the issues in society that affect people are dealt with by the church and more often than not, the church; as an institution, takes on the characteristics of the adherents that make up the church. 


\section{Role of Women}

One significant change in society that has been reflected in the church is the role of women. Society has increasingly empowered women to take leading roles in the management of organizations and institutions and this is seen directly in the employment practices of the Seventh-day Adventist Church in Britain. Toleration of women in managerial and directorial positions in the church administration is a reflection of the toleration of women as entrepreneurs and managers in the secular business environment. However, the true test of tolerance for the church has been the acceptance of women as pastors of churches and itinerant lay-preachers. Over the past thirty years there has been an increase in the number of women who have been trained for these roles. There has been a minority of "traditionalist" hardliners who have refused to accept a woman preaching the Word of God or assuming the role of elder; nevertheless, these are a minority and the majority of the church membership has welcomed the change with open arms. So much so that a significant number of churches now have women serving as elders and making a vitally important contribution to the pastoral and administrative needs of the churches. Within the last decade the South England Conference alone, that previously had only employed women as Bible workers, has employed a total of four women who started as associates in pastoral care, and were later upgraded to licensed ministers. ${ }^{1}$

The issue of women participating in the decision-making process of the church is reflected in the sudden increase of a female presence on the British Union Executive

\footnotetext{
${ }^{1}$ Data taken from South England Conference Workers Directories, 1991-2002.
} 
Committee. As figure 2 illustrates, prior to 1976 no women were invited to share in this process, but within the past three decades there has been a considerable increase. In 1996 out of a total of 31 members, 6 were women, even though one might conclude that it still does not reflect the observable predominance of females in the membership of the Seventh-day Adventist Church in Britain.

\section{Increase in Lay Decision Makers}

The involvement of lay members in the administrative work of the church has increased considerably. Figure 2 clearly shows that involvement on the conference committees has reached a majority ratio and this suggests that the reliance on ordained leadership is no longer considered to be a revered necessity. Even the British Union Committee reflects a great increase of lay involvement. Figures 3 and 4 indicate the increases seen over recent years.

\section{Willingness to Break from Tradition}

There is a greater insistence on professionalism from the laity on the part of the clergy and that professional lay members should be employed to fulfill roles and jobs that do not demand ordination. The number of lay members who are willing and eager to be trained as lay preachers is also an indication that the clergy are not the only ones who are considered able to speak with authority. In the South England Conference alone, in 2002, there were 59 applications from male and female lay members for training in lay preaching of which there were 34 graduates. The following year saw 64 applications 
with 27 graduates. ${ }^{1}$ The graduates returned to their local churches and have contributed greatly to the preaching ministry.

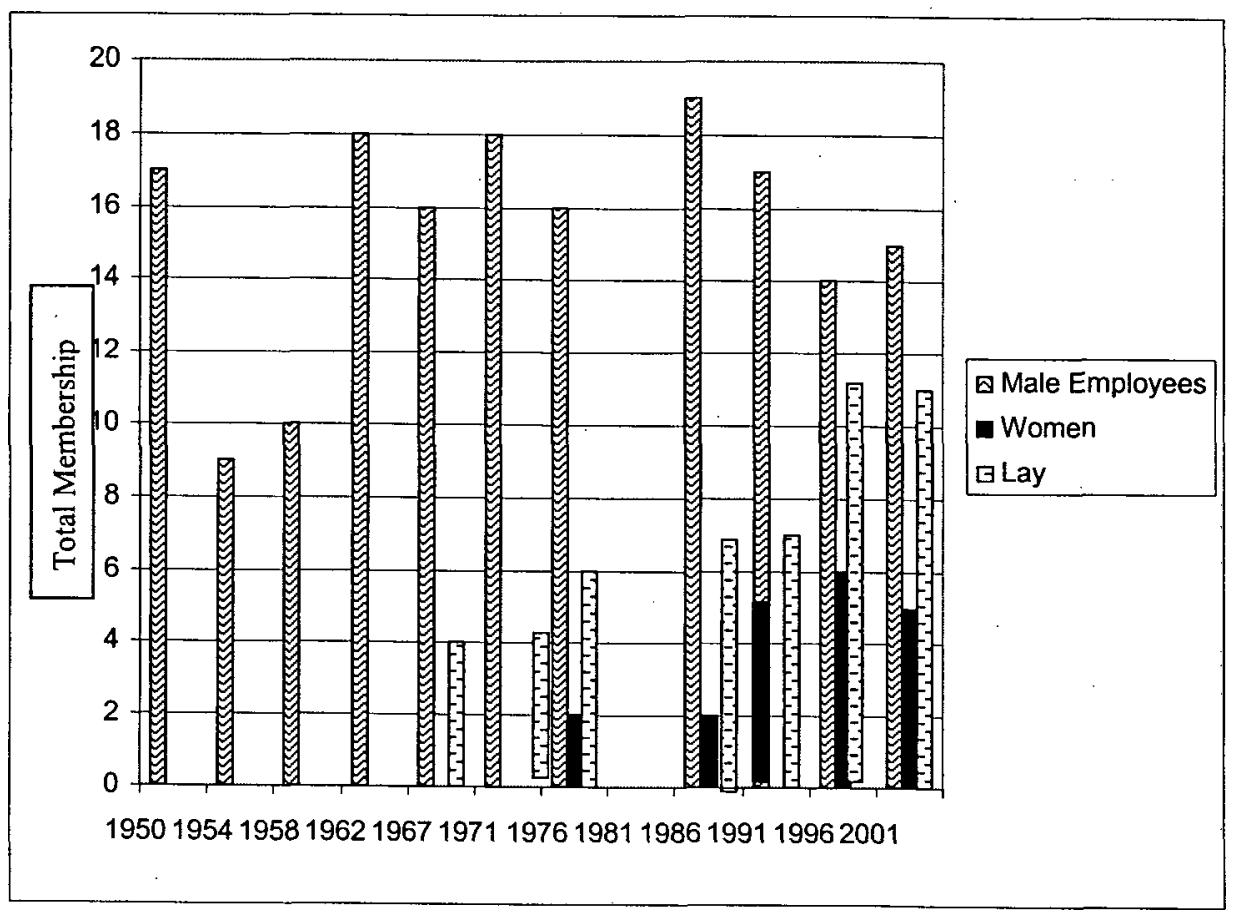

Figure 2. B.U.C. Executive Committee, 1950-2001.

Source: British Union Conference (Watford, England), "Minutes of the British Union Conference Session Report," 1950-2001. Data for 1981 not available.

${ }^{1}$ Information taken from South England Conference Lay Preachers registration application data, 2002 and 2003. 


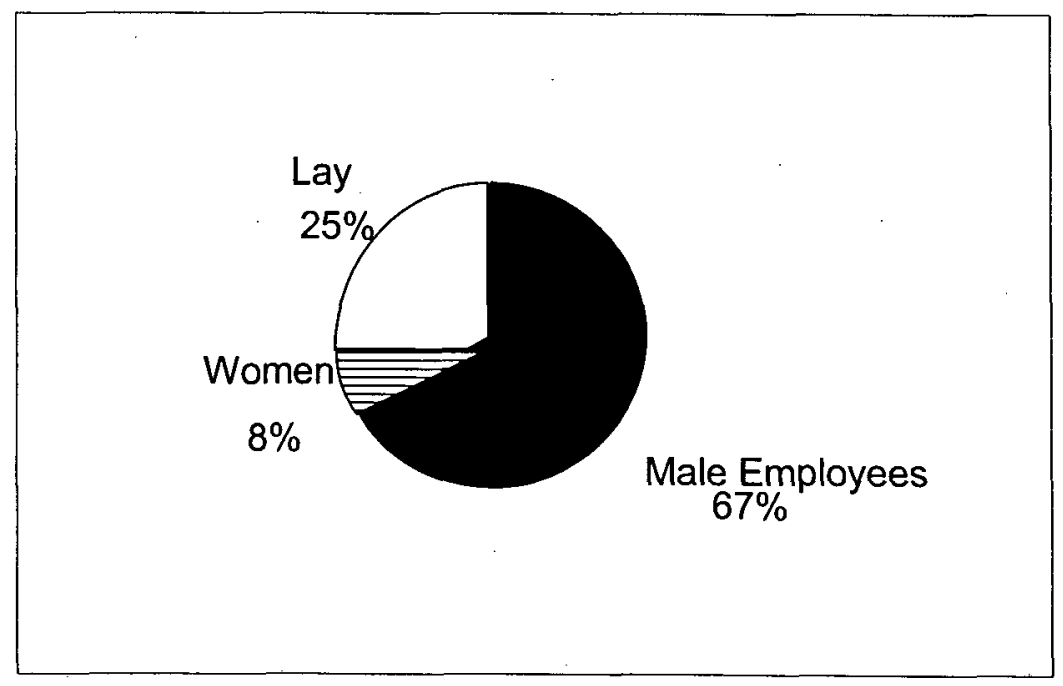

Figure 3. B.U.C. Executive Committee Membership Percentages, 1976. Taken from British Union Conference (Watford, England), Minutes of the BUC Session Report, 1976.

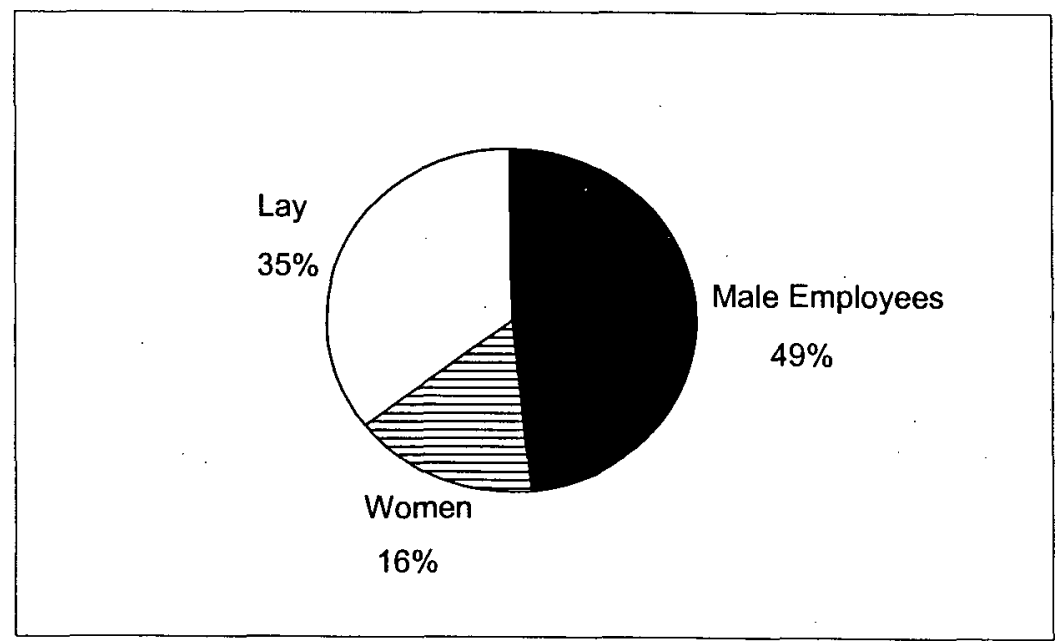

Figure 4. B.U.C. Executive Committee Membership Percentages, 2001. Taken from Britiș Union Conference (Watford, England), Minutes of the BUC Session Report, 2001. 
The demand for a greater use of the media has forced some ministers to tailor their ministry and presentations toward a media-conscious congregation. The computer has become an integral part of the minister's tool for ministry. The mobile telephone has allowed the pastor to be more accessible to the members of the congregation, and the learning of text messaging language has become an asset for communicating with the younger members of the congregation especially.

Evangelistically, it is evident that people are not responding in the same way to large-scale public evangelistic efforts but are rather responding to the more relational approaches. Ministers also are steering away from traditional public campaigns and are instead, moving toward the seminar and small group relational methods.

Traditionalism has been challenged by the changed attitude of the church membership. Members are insisting that the ways things have always been done are not necessarily the way they must continue to be done. They are willing to break with tradition and, as one might observe in some of the churches throughout the British Union, this has caused a rift between the hard line traditionalists and the "change makers."

This rift is seen more markedly in the attempt in some churches to modernize or use contemporary forms of worship. The use of a greater variety of musical instruments in the sanctuary is one change that many traditionalists are very unhappy with, claiming that it is a sign of worldliness and a compromise of Seventh-day Adventist principles. However, there are churches that have embraced the change and believe that it allows opportunity for freedom of expression in worship and for variety in worship styles.

Formality in dress during worship is a subject that is calling for some debate in the twenty-first century changing church. The traditional Sabbath attire or "Sunday best" 
is no longer considered to be a necessary part of the worship experience. Especially in the case of men wearing ties and suits is this change seen. The younger mindset do not see the sense in having to wear a suit and tie when informal dress in no way detracts from one's experience with God; uniformity is not a prerequisite for faith or grace.

Related to formality of dress is the questioning of traditional Adventist interpretation of the wearing of jewelry. A generation has been brought up to accept the fact that Adventists do not wear jewelry without ever daring to ask why. Many baptized church members can quite confidently dress with jewelry and claim that it does not affect their Christianity and as long as they feel comfortable wearing it, that should be of no concern to anybody else.

Society is increasingly becoming more indifferent toward institutions. They are not afraid to criticize the institution if they consider it to be behaving in an unsatisfactory manner. Its leaders are considered to be answerable to the general public and not to themselves. The days of reverence for leaders of institutions are fast receding and leaders are becoming increasingly aware that the "voice of the people" is what really counts, and is heard the loudest.

The church as an institution, with a centralized management and bureaucracy is progressively being undermined, by the general public and its members. The church is seen to be more effective if the local leadership runs it rather than having policies and plans handed down to it from the hierarchy. This has led to the Seventh-day Adventist churches in the north and south of England dividing up their conference territory into smaller working units, known as areas and districts. Even though these are led by an employed minister they are, nevertheless, greatly influenced by the local lay leadership. 
Seventh-day Adventist Response

The cultural and religious changes that have taken place in the United Kingdom over recent years have led to the Seventh-day Adventist Church being what it is today. The cultural make up of the church is reflective of the society in which it has been nurtured. In this instance it is important to make the distinction between the cultural make up and the ethnic make up. What is meant by cultural make up are the changes that have affected British society as a whole, and the attitude change that has been adopted by all ethnic groups. With these changes it is therefore, difficult to make a distinction between the culture of society and the culture of the church. In this respect, the Seventhday Adventist's response to cultural change is not totally dissimilar to society's response to the same.

There is evidence that society has become more tolerant in certain respects and on the subject of tolerance, the Seventh-day Adventist Church in Britain has gone through some turbulent times. The major turbulence was experienced in the acceptance of immigrants into the established churches in the major cities of Britain, especially those of England. Concerning the West Indian Adventist immigrants D. S. Porter records, "The attitude of the existing membership in the $1950 \mathrm{~s}$ and $1960 \mathrm{~s}$ is hard to determine. Often it probably took the form successively of welcome, puzzlement, departure. The average British Adventist had seen an occasional black visitor in his church. . . He would be welcomed; indeed, in some cases almost lionized. He was the missions appeal come to life. ... After a week, a month, a year, he would go away. The earliest West Indians 
were received in much the same manner, but they did not go away. They kept on coming to Brixton, Holloway, Chiswick, Lewisham."1

The rapid influx of immigrants into Adventist churches in England led to many English members leaving their existing churches and forming companies made up of exclusively white members. ${ }^{2}$ This period of major intolerance was reflective of the unease that existed in society at large, as a result of immigration.

The church's response to this intolerance resulted in what was known as the "Pierson Package," 3 a policy that was intended to foster greater tolerance, integration, and cooperation between the conferences and British Union leadership and the church's major ethnic groups, namely Black West Indians and White indigenous. It was a policy that recommended the employment of Black ministers for the churches and appointment of one Black officer within the conference administration to work alongside White administrators. ${ }^{4}$ This policy has been in operation since 1978 and moves are afoot to unofficially sidestep this policy. The general feeling among the members of the church is that the church should be led by the best "man" for the job and not by ethnic quotas. This sign of maturity in tolerance was demonstrated at the 1999 South England Conference Session when the "Pierson Package" was overruled by the delegation.

'D. S. Porter, A Century of Adventism in the British Isles, Messenger: Centennial Historical Special (Grantham, UK: The Stanborough Press, 1974), 42.

${ }^{2}$ Ibid.

${ }^{3}$ Orville Woolford, "The 70s Struggle: A Black Perspective," Messenger-9 $90^{t h}$ Anniversary Souvenir Edition 1902-1992 (Grantham, UK: The Stanborough Press), 34.

${ }^{4}$ Ibid. 
Contemporary thinking suggests that people are more relational and spiritual than they are religious and therefore need an approach that is non-threatening and allows for the power of choice to be exercised. As a result the church leadership in Britain has encouraged the members of the church to develop relational ministries. Small group ministries have been encouraged through the conferences with considerable success. These groups are intended to build relationships and do not have to be overtly religious in their approach. The emphasis on meeting the needs of the community is played out in these groups, and a growing representation of churches such as the Stoke Newington Church in North London, and the Milton Keynes Church in Buckinghamshire, are not just opened on a Saturday morning for worship, but are inviting the community into their buildings during the week to participate in community activities. In describing contemporary society, Grenz suggests, "In the postmodern world, we can no longer follow the lead of modernity and position the individual at centre stage. Instead we must remind ourselves that our faith is highly social. The fact that God is the social TrinityFather, Son, and Spirit-gives us some indication that the divine purpose for creation is directed toward the individual-in-relationship. Our gospel must address the human person within the context of the community in which people are embedded."1

An attempt to reach the "twenty-first century mind" has resulted in plans to broadcast via satellite messages that will appeal to the unchurched, secular thinking, young adult. Its aim is to present the message of the church as a holistic lifestyle, presenting the differences it has made to lives of Adventist Christians and the difference it can make to other lives in the community. This holistic lifestyle approach is more

\footnotetext{
'Grenz, 168-69.
} 
relational rather than the traditional theological emphasis. Preparations for this are via members' creating friendships and group relationships, supported by what is known as "Life. Info" magazine; a magazine aimed at the unchurched, secular thinker. Initial verbal reports from the editor of the magazine critique it as being perhaps the most successful magazine ever produced by the church in Britain for the general public.

Investments and resources made available for the reaching of the local secular and unchurched communities suggest strongly that the Seventh-day Adventist Church in Britain is serious about reaching this sector of the population. The church has demonstrated proactively through traditional and modern methods of evangelism that the gospel can be preached to all generations and that they are not afraid to try whatever is necessary to accomplish their task. The challenges for the church however, is to mobilize every available member to think seriously about their individual calling and support the organized church in achieving the ambitious goals that have been set for her. These challenges will become increasingly difficult to surmount if each member is not alert and aware of their spiritual gifts given for a twenty-first century generation: a generation that needs to be reached before a new generation prepares to be born. These challenges must be faced and changes must be made wherever necessary to accommodate greater involvement and growth.

The mandate for change in order to facilitate greater involvement in ministry is not merely sociological, it is also theological. One virtue that many Seventh-day Adventist churches in Britain lack is the courage to change-holding to tradition is far easier. There are, however, references in Scripture to suggest that holding to tradition is not always the best means of creating the environment for involvement. There are those 
among the traditionalists who are quick to make reference to the fact that God said that he is God and he does not change, therefore the sons of Jacob are not consumed (Mal 3:6). They misunderstand the principle that God's love for his people does not change, and his willingness to save does not change. Because of his willingness to save however, he is ready to change wherever necessary for the benefit of humanity.

The ministry of Christ so exemplified the willingness of God to change that the Pharisees, the traditionalists of his time, put up such stiff opposition that caused Christ to denounce their service to God as meaningless because tradition had become the basis for ministry. One significant change instituted in the New Testament was that of the change of the Passover service for Jews to that of the Lord's Supper for Christians. One might also mention circumcision for Jews to baptism for Christians. In the Christian church in the first century there was opposition from the traditionalists who felt that the traditions were being eroded in place of new methods and new experiences. The Jerusalem Council met (see Acts 15) to discuss some of the perceived changes and agreed to endorse them, resulting in greater growth for the early Christian believers. 


\section{CHAPTER IV}

\section{THEOLOGICAL FOUNDATION FOR LAY INVOLVEMENT}

\section{Call for Lay Involvement}

It is very unfortunate that such a major distinction is drawn between the "laity" and the "clergy" within the Christian community. It is a distinction that is not only made by Christians themselves but also by those who are outside of the Christian faith. This is so deeply ingrained in society that to digress or attempt to use non-distinct references would cause much confusion. However, despite the difficulty it is necessary to outline the biblical and theological usage of the terms in order to lay a foundation for future discussions.

The word "laity" traditionally refers to people within the church community who are neither ordained nor paid to perform specific ecclesiastical duties; the word "clergy" refers to "the body of all persons ordained for religious services." However, a point of interest worth noting is that in biblical literature and in the writings of the early church fathers, there are no references giving this distinction. In fact it is not until after the death of the last apostle, approximately 200 years later, in the writings of Clement of

\footnotetext{
${ }^{1}$ The Concise Oxford Dictionary of Current English, $6^{\text {th }}$ ed., s.v. "Clergy."
} 
Alexandria, that the first references appear. ${ }^{1}$ Up until that time there were distinctions in leadership responsibilities, but not in ministerial calling and effectiveness.

In 1 Pet 2:9-10, Laos, from which is derived the English word "laity," refers to the common people, those who were not baptized and who were shown mercy. Upon baptism they became the saved of God and were referred to as the hagioi, the holy ones, or as is often translated, "the saints" (see, for example, Acts 9:13; Rom 8:27; 1 Cor 6:2; Rev 14:12). Kleeros (from which we get "clergy"), on the other hand, refers to those chosen by lot, ${ }^{2}$ and in the biblical context, is a better description of the people of God being his chosen possession.

Scripture teaches that people are called by God to follow the example of Jesus. While on earth Jesus was a layman. He did not belong to the order of the priests, nor was he a descendant of the Aaronic priesthood. He was never employed in the temple; he only went there to perform miracles, teach the people, and defend the rights of the poorer classes. His major role was that of a prophet, and a servant of the people. "The ministry of the Servant of Yahweh was first of all to proclaim God's word of Justice. His second function was to suffer and to offer his suffering as an intercession for the sins of the people. This suffering would bring about the healing of the people, free them from their sins and restore them to wholeness." 3

${ }^{1}$ Michael J. Christensen and Carl E. Savage, eds., Equipping the Saints: Mobilizing Laity for Ministry (Nashville, TN: Abingdon Press, 2000), 42.

${ }^{2}$ Exegetical Dictionary of the New Testament (1981), s.v. "kleeros."

${ }^{3}$ William J. Rademacher, Lay Ministry: A Theological, Spiritual, and Pastoral Handbook (New York: Crossroad, 1991), 14. 
There are numerous examples in Scripture of lay people who were called by God for a special purpose. The book of Judges in the OT is filled with such people. People such as Deborah (Jud 4-5), the first female judge of Israel; Gideon (Jud 6-9), who was called by God to lead Israel against the cruel Midianites; and Samson (Jud 13-16), who defeated so many of the enemies of Israel. The NT is able to cite all the disciples of Christ as being lay men called for a special purpose. This demonstrates that the call of God is not subject to any professional status of any kind.

God calls people first of all that they might be a blessing to others. Abraham was called that he might be a blessing to all peoples of the earth (Gen 12:3); Moses was called to make a difference in the lives of a whole nation (Exo 3:9,10); the disciples of Christ were called to preach the good news of salvation and make disciples of all men (Mark 16:16-18). William Rademacher states, "The people are called, not for themselves, but to accomplish God's purpose (Rom 8:28). They are called for a mission. The call is never separated from that mission which actually defines the call. The call is a means to an end-Israel is to be a blessing to the Gentiles."1

It is also evident in Scripture that the call of God is to service. His instructions to his disciples and through them to the other Christians are unambiguous. They were to be light to the world (Matt 5:13-16); co-labourers with God (1 Cor 3:9); and conveyers of his glorious works (1 Pet 2:9).

Baptism was the initiation for service. This is demonstrated by Jesus himself (Mark 1:9) and carried forward by the disciples and early Christians. They made it clear

\footnotetext{
${ }^{1}$ Ibid., 27.
} 
that baptism by water and the Holy Spirit are clear signs of one's readiness to enlist in the services of God. For them there was no distinction between clergy and non-clergy roles. As far as they were concerned, "'Ordination' to the laity was effected by the sacrament of baptism." It was here that they received their commission and authorization to serve.

Because all baptized believers were seen as having been enlisted into the service of God the teaching of the "priesthood of all believers" was supported not only by the apostles and early Christians, but also by the early church fathers. For example, Turtullian (A.D. 155-222) taught that power and authority in the church was given by Christ to all "spiritual men,"2 and it was as universal as the Holy Spirit. He goes further in his argument by suggesting that the sacrament of baptism should not only be conducted by the "president of the brethren" or the deacons, but also, in special circumstances, by the laymen. ${ }^{3}$ The concept of the church as a "royal priesthood," referred to in 1 Pet 2:9, appears to be in reference to the whole church and not to individuals within the church. Collectively, the church is a kingdom of priests and so represents the common people, the laity, to God.

The concept of the people of God being baptized for service is further amplified by the language of the apostle Paul. Three Greek words used by Paul to describe the work or the operations of the Holy Spirit in the lives of the baptized Christian are:

${ }^{1}$ Stephen Charles Neill and Hans-Ruedi Weber, The Layman in Christian History (London: SCM Press Ltd., 1963), 31.

${ }^{2}$ Cyril Eastwood, The Royal Priesthood of the Faithful: An Investigation of the Doctrine from Biblical Times to the Reformation (London: The Epworth Press, 1963), 74.

${ }^{3}$ Ibid., 75. 
charismata, meaning the "gift of the Spirit," diakonia, meaning "to serve at a table," and energemata, meaning "effectual workings." These gifts are given to the entire baptized community, not just to the ordained persons. Rademacher states that, "The horizon of the Spirit in baptized men and women is a life which is charismatic in terms of its source, but diaconal in terms of its goal. Spirit leads to ministry. The value of these charisms is not in their possession, but in their exercise for the benefit of the community. They are all functions: preaching, healing, teaching, giving aid, discerning, etc. They are not states of life."

The compulsion for Christian service and influence is emphasised by Stephen Neill who reminds us that, "Strictly speaking neither a history of the laity nor a theology of the laity can be written. The whole Church is the laos, the people of God. If its history is correctly written, the life of the Church will be displayed in all its manifold variety and in all its complexity of its relationships with the world outside itself. The whole body of the Church is priestly."3

If the church is to penetrate the world and influence it for the Lord it must depend on its laity. In its priestly role the laity is the church's main contact with the world. Therefore, the laity is the number one player in representing the sacred to the profane, the religious to the secular. However, it is at this juncture that the laity encounters its greatest challenges. Neill and Webber suggest that if the laity is to be influential it must

\footnotetext{
${ }^{1}$ See TDNT, s.v. "charismata."

${ }^{2}$ Rademacher, 32.

${ }^{3}$ Neill and Weber, 15.
} 
face three different challenges as it strives to uphold the ideals of Christianity. Firstly, there is the challenge of personal integrity in the work place: the challenge to labor for the sake of the job and not for reward. The Christian worker may be tempted by the impure motives of his secular colleagues, however, yielding must be beyond him. Secondly, there is the challenge of the Christian being regarded as the servant to society where what he does is not seen in the light of just a job but as a service to the community. The Christian must consciously maintain that philosophy with his working environment despite any financial incentives that there might be. Thirdly, the Christian must consider the Christian significance of his work. Does being a Christian make any difference to the job that he is engaged in? ${ }^{1}$

With this broadened view of the role and influence of the laity one is able to better appreciate the benefits to the person and the effectiveness of the church in the local community.

\section{Ministry of Women}

The Scriptures make it very clear that there is no distinction in the effectiveness of the witness of the male laity and the female laity. The increased inclusion of women in the work and leadership of the church is an indication that God, indeed, shows no partiality between the two human genders. God is revealed through all cultures and likewise through all genders.

Women in biblical times have played a very significant role in demonstrating lay involvement in ministry. There are numerous examples of women who have been led

\footnotetext{
${ }^{1}$ Ibid., 22-24.
} 
and used by God to accomplish great achievements, thus setting a biblical precedent for more involvement of women in ministry generally, but more specifically, in local church ministry.

It is helpful to point out the prophecy of Joel 2, where the promise of the power of the Holy Spirit is to be given to all flesh. "Then after I have poured out my rains again, I will pour out my Spirit upon all people. Your sons and daughters will prophesy. Your old men will dream dreams. Your young men will see visions. In those days, I will pour out my Spirit even on servants, men and women alike" (Joel 2:28-29 NLT; emphasis mine). This prophecy was repeated by the apostle Peter on the Day of Pentecost recorded in Acts 2 indicating that the phenomenon that the crowd was experiencing, which included women being empowered for ministry, should not be considered as strange (see Acts 2:14-21). A mention of all women cited throughout the NT does not fall within the scope of this paper; however, a mention of Mary of Bethany, the sister of Martha and Lazarus, is an example of women inspired for ministry. Her act of ministry was among the few that were commended by Christ (Mark 14:3-9).

The apostle Paul met fellow tent maker Aquila and his wife Priscilla in the city of Corinth. This husband and wife team are portrayed as being skilled in their understanding of the word and were able to teach others (Acts 18:26). They were also commended by Paul as being co-workers with him in his ministry for Christ (Rom 16:3).

In his counsel to Timothy (3:11), Paul outlines the virtues to be seen in the female workers for the Gospel. These virtues are the same as that of their male counterparts and in addition women are to "be respected and must not speak evil of others. They must exercise self-control and be faithful in everything they do" (1 Tim 3:11, NLT). These 
deaconesses, or "female servants," are filled with the Holy Spirit, as was promised in the prophecy of Joel, and so the twenty-first century church must expect a greater involvement of women enlisting at all levels of service in the church. Since the Protestant Reformation women have played a major role in the proclamation of the Gospel and the work of the church. From the theology of Martin Luther, to the preaching of John Wesley, many women had been empowered to take their religion seriously and become more active. Laywomen in the eighteenth century such as Mary Thomas, Sarah Middleton, and Margaret Austin all expressed the difference that evangelical revival had made to their involvement in the Gospel proclamation, ${ }^{1}$ and throughout the nineteenth and twentieth centuries many had taken their stand. It goes without saying that the majority of the church membership is women and if the majority of members must become involved in ministry then we must see more women fulfilling more prominent roles.

\section{Need for Spiritual Mentors}

The Scriptures have numerous references and models of mentoring. Both the Old Testament and New Testament demonstrate that this model of training is the most effective in producing qualified and effective workers for God. An exploration of the OT will reveal perhaps the most successful mentor-mentee relationship-that of Moses and Joshua.

${ }^{1}$ Bruce Hindmarsh, "Reshaping Individualism: The Private Christian, Eighteenth Century Religion and the Enlightenment," in The Rise of the Laity in Evangelical Protestanism, ed. Deryck W. Lovegrove (London: Routledge, 2002), 69. 
Joshua is first mentioned in Exod 17 as a soldier who led the nomad army of Israelites in victory against the Amelakites. Soon after this event he is named as Moses' assistant (Exod 24:13) who went up into the mountain to meet with God. It is interesting that Aaron, Nadab, and Abihu, and seventy elders went up also but Joshua and Moses went on further. It is obvious that Joshua stayed close to Moses in order to learn personally, the intimate details of leadership. It could be that Moses' example as a mentor to Joshua gave him greater faith in times of crisis and it prepared him for greater service. Joshua observed Moses' vulnerability; he heard his criticisms; he saw his failings and his successes, and at the end of Moses' term in office, at God's command, hands were laid on Joshua and he was commissioned to succeed his mentor in doing the job that he had been prepared for.

Mentoring has also to do with building confidence and this was modeled in the NT by Barnabas and Paul. Acts 9:26-28 records the distrust that existed among the Christians concerning Paul, due to the persecution which he had previously inflicted on the church. He ran the risk of ostracism from the group but Barnabas spoke up for him, recommended him to the other disciples and later accompanied him on his first missionary journey. Paul was obviously a man of great experience but needed a mentor to encourage him and to represent him before those who had no confidence in him.

In the context of the church the leaders must offer "spiritual" mentoring to the uninvolved member. Kuhlman suggests that a spiritual mentor is, first of all, a "spiritual friend" who is spiritually mature and "has a deep peace gained through the difficulties of 
life." A spiritual mentor will listen deeply, not just superficially to what is said but to discover who the other person is. Mentors will be people of prayer because prayer is the key to understanding God, his purpose, and workings in our lives. ${ }^{2}$ The leaders who will be selected will need to be aware of their spiritual role which will include a high level of confidentiality and trust.

Commenting on mentoring as a means of training and developing people, Rosemary Thomson states, "There is a sense in which the mentoring relationship is similar to that of the 'master-pupil' relationship in medieval times; the pupil is learning from the mentor's experience and the mentor's role is to encourage and nurture his or her protégé. Mentors can pass on practical insight derived from experience and can pick up on new ideas and attitudes. They can help their protégé to set themselves realistic expectations and steer them in the right direction as far as their career aspirations are concerned."

The mentors are leaders who will need to become aware of the mentee's readiness to follow and participate in achieving the objectives of the project. Being aware of this readiness may involve being able to adjust one's leadership style to accommodate the mentee.

${ }^{1}$ Delcy Kuhlman, Experiencing God through Spiritual Mentoring: Coming Together (Lincoln, NE: AdventSource, 1998), 33.

${ }^{2}$ Ibid., 48.

${ }^{3}$ Rosemary Thomson, Managing People (Oxford, UK: Butterworth-Heinemann, 1993), 111. 
In their discussion on situational leadership Paul Hersey and Kenneth Blanchard suggest that leadership styles must be determined by, and have a direct correlation with, those who are following. ${ }^{1}$ Leadership style is determined by the maturity of the follower regarding any given situation or issue at hand. The method used to influence people is determined by "the readiness level of the people the leader is attempting to influence."2 They go on to suggest, "Readiness in Situational Leadership is defined as the extent to which a follower has the ability and willingness to accomplish a specific task. People tend to be at different levels of readiness depending on the task they are being asked to do. Readiness is not a personal characteristic; it is not an evaluation of a person's traits, values, age, and so on. Readiness is how ready a person is to perform a particular task."3

The readiness level of the follower determines one of four leadership styles.

These are: (1) Delegating: that turns over responsibility for decisions and implementation to the follower; (2) Participating: that shares ideas and facilitates the follower in decision making; (3) Selling: explaining decisions and providing opportunity for clarification, and (4) Telling: that provides specific instructions to the follower and closely supervises his/her performance. ${ }^{4}$

\footnotetext{
${ }^{1}$ Paul Hersey and Kenneth H. Blanchard. Management of Organizational Behavior: Utilizing Human Resources, $5^{\text {th }}$ ed. (Englewood Cliffs, NJ: Prentice-Hall International, Inc., 1988), 170.

${ }^{2}$ Ibid., 171.

${ }^{3}$ Ibid., 174.

${ }^{4}$ Ibid., 171.
} 
The leadership style is further distinguished by whether the leader's behavior is task oriented or relationship oriented. "Task behavior is defined as the extent to which the leader engages in spelling out the duties and responsibilities of an individual or group. These behaviors include telling people what to do, how to do it, when to do it, where to do it, and who is to do it." On the other hand, "Relationship behavior is defined as the extent to which the leader engages in two-way or multi-way communication. These behaviors include listening, facilitating, and supportive behaviors."2

These leadership behavior orientations are important to mentoring because they help the mentor to determine how to deal with uninvolved members whom they are supervising. Depending on the member's level of motivation to a particular task or situation the mentor would adjust the behavior accordingly for the purpose of helping the trainee grow and mature in the assigned task. "In working with others and helping them grow, leaders should have positive assumptions about followers' potential. Effective leaders believe that people have the potential to grow and, given an opportunity, can and will respond."3

Growth and professional development of the mentee must be the goal of the mentor and the importance of this role must not be underestimated. As the mentor appraises the mentee's performance on an on-going basis, the performance and professionalism of the mentee in their ministry is improved. Commenting on career

\footnotetext{
'Ibid., 172.

${ }^{2}$ Ibid.

${ }^{3}$ Ibid., 174.
} 
development Thomson suggests that self development needs to be related to personal strengths and weaknesses and to one's personal career aspirations. ${ }^{1}$ The same must apply to one's aspirations in ministry.

The readiness level of the "follower" or in this particular case, the uninvolved member, can be described in terms of ability and willingness. According to Hersey and Blanchard, "Ability is the knowledge, experience, and skill that an individual or group brings to a particular task or activity. Willingness is the extent to which an individual or group has the confidence, commitment, and motivation to accomplish a task." ${ }^{22}$ These two factors are always a challenge to the mentor. The uninvolved member can either be willing or unwilling; or he or able or unable. These two factors can also be expressed in terms of "confidence" and "insecurity"; confidence, indicating their ability and willingness to perform, and insecurity indicating their inability or unwillingness. ${ }^{3}$

Mentoring is not a discipline that is widely practiced in the Seventh-day Adventist Church. In areas where it is practiced, it is usually among the professional clergy and even then, it is somewhat limited in its scope. When mentoring is fully established and becomes a norm among the lay members then greater growth will stem from greater involvement.

\footnotetext{
${ }^{1}$ Thomson, 115.

${ }^{2}$ Hersey and Blanchard, 174.

${ }^{3}$ Ibid., 176.
} 
Mentoring uninvolved members does not have to come from the professional clergy but rather it will be more effective when it is offered by the lay leadership in the church. Those who are already involved have a wealth of experience and knowledge to pass on to others, and so the professional's job is to train the involved leaders to mentor those who are uninvolved. This can be described as power-sharing. The professional sharing his experience with the involved member who, in turn, shares his or her experience with the uninvolved, who then is coached to share their experience in ministry. Commenting on mentoring in the university setting, Cathie Ann Schweitzer points out that "mentors also benefit from the process. They learn, grow, and are able to have a greater effect on students. They have the opportunity to exercise their leadership abilities. Many mentors expressed a renewed sense of professionalism as a result of participation in the program.",

\section{Motivating People for Ministry}

It will be important for mentors to appreciate the principles of motivation in order to effectively move the uninvolved members to a place of self-motivated involvement. The mentors and leaders may be dealing with members who may be disillusioned for a variety of reasons and this may have affected their level of involvement. John Savage emphasized that members who become inactive in the church community usually transition from a state of "helplessness" to one of "hopelessness.", The feelings of

'Cathie Ann Schweitzer, "Mentoring Future Professionals," The Journal of Physical Education, Recreation and Dance 64, no. 7 (1993): 50.

${ }^{2}$ Savage, 51 
helplessness originate from a dysfunctional childhood and are played out in adult life. $\mathrm{He}$ states, "It is this helpless feeling that leads to apathy. Apathy, therefore, is the feeling that nothing in my environment can come to my aid. As helplessness is the time of giving-up, apathy is the stage of having given-up. The person no longer engages the environment and, therefore, does not ask for help."1

"As the apathetic person is not able to find help from the outside world to solve his or her problem, the bored person comes to the point of dropping out because of a lack of inner resources." ${ }^{2}$ The inevitable feelings of unworthiness, guilt, and shame develop which leads to feelings of hopelessness and the withdrawal from relationships and activities. "When an anxiety setting is encountered and one is not able to cope with these strong feelings, the adult will move away by turning the anger on himself or herself, feel guilty, and quietly leave the church. These feelings produce a sense of hopelessness and ultimately boredom. Bored adults are those who have poor self images and tend to punish themselves for anything that goes wrong."3

From his research, Savage discovered that active church members showed no sign of helplessness or hopelessness whereas there was a distinct shift in orientation as members became less active. ${ }^{4}$ In his conclusion he points out that there is a direct

\footnotetext{
${ }^{1}$ Ibid., 63.

${ }^{2} \mathrm{Ibid}$.

${ }^{3}$ Ibid., 64.

${ }^{4}$ Ibid.
} 
correlation between church activity and the ability of church members to engage in meaningful conflict resolution. ${ }^{1}$

Fear of failure is a demotivating factor, whereas an assurance of success is in itself motivating. A member who fears ridicule and shame if a particular taks should be unsuccessful is likely to lack the motivation to become involved in any related tasks. Hugh Wagner, when referring to Atkinson's linking of achievement motivation theory with emotional outcomes, says that when a person is unsure of the outcome there is a conflict between whether to approach a situation or to avoid a situation. ${ }^{2}$ He describes the person as experiencing "approach-avoidance dilemma." Wagner states, "The person's tendency to take on the challenge (approach) is determined by the combination of the person's need for achievement, the perceived probability of success and the incentive value (reward) of success." ${ }^{\text {"4 }}$ Similarly, avoidance is determined by the degree of fear, the perceived probability of failure and the negative incentive for the behavior. ${ }^{5}$

${ }^{1}$ Ibid., 97. 1999), 143.

${ }^{2}$ Hugh Wagner, The Psychobiology of Human Motivation (London: Routledge,

${ }^{3} \mathrm{~J}$. W. Atkinson in An Introduction to Motivation (New York: Van Nostrand Reinhold Company, 1964), 180.

\footnotetext{
${ }^{4}$ Wagner, 143.

${ }^{5}$ Ibid.
} 
Reginald McDonough suggests, "Motivation is something that stems from within each individual." It is not something that is manipulated by others but rather is the outgrowth of an inner desire to be involved with, and be a part of whatever is happening. Self-motivation gives each person responsibility for their own actions and also helps the leader to understand their role of creating a climate in which the person can become motivated. $^{2}$

Influenced by Abraham Maslow's hierarchy of needs, McDonough suggests four keys to effective climate building for motivation: (1) Stability: People will withdraw from activity when they feel insecure in the environment. The leader or mentor must then create a safe and secure environment in order for the person to feel safe to participate. They must feel safe enough to risk exposure. (2) Teamwork: Teamwork is based on the need for belonging and acceptance. The environment must be such that the person can give and receive affection. This is ideal in small group settings. (3) Affirmation: Affirmation is based on the person's need for positive self-esteem. The ability to receive positive feedback from others will build a person's self-esteem and motivate the person to aspire to greater involvement. (4) Challenge: Challenge relates to the person's need for purpose, meaning, and achievement. A person must have something to be excited about and challenged to aspire to, ${ }^{3}$ thus echoing apostle Paul, "Not that I have already obtained all this, or have already been made perfect, but I press on to take hold of that for

${ }^{\mathrm{l}}$ Reginald M. McDonough, Keys to Effective Motivation (Nashville, TN: Broadman Press, 1979), 72.

${ }^{2}$ Ibid., 73 .

${ }^{3}$ Tbid., 79-82. 
which Christ Jesus took hold of me. ... But one thing I do: Forgetting what is behind and straining toward what is ahead, I press on toward the goal to win the prize for which God has called me heavenward in Christ Jesus" (Phil 3:12-14 NIV).

The motivation of uninvolved members involves identifying an unsatisfied need that relates to the members' natural desire to feel fulfilled or self-actualized in the environment of the church or community. ${ }^{1}$ According to Hersey, Blanchard and Johnson, if that need is not met, then that energy will be channeled into some other activity that satisfies the original need. It is the challenge of the church leadership therefore, to help members fulfill their needs in the mission of the church which means identifying the strengths and potentials and ultimately to find expression in ministry. Viktor Frankl states that "the striving to find a meaning in one's life is the primary motivational force in man." These sentiments are echoed by Thomas Peters and Robert Waterman in writing that "the dominating need in human beings is to find meaning, ... to control one's destiny, ... to be an expert in the promotion and protection of values."

In Abraham Maslow's hierarchy of needs it is noted that the physiological needs are at the top of the hierarchy. However, this need ceases to be the strongest once it has

${ }^{1}$ Paul Hersey, Kenneth H. Blanchard, and Dewey E. Johnson, Management of Organizational Behavior: Leading Human Resources, $8^{\text {th }}$ ed. (Upper Saddle River, NJ: Prentice Hall, Inc., 2001), 26.

${ }^{2}$ Viktor Fankl, Man's Search for Meaning: An Introduction to Logotherapy, trans. Ilse Lasch (London: Hodder and Stoughton, 1962), 99.

${ }^{3}$ Thomas J. Peters and Robert H. Waterman, Jr., In Search of Excellence: Lessons from America's Best Run Companies (New York: Harper and Row, 1982) 76, 80, 85. 
been met. It then gives way to the safety, social, esteem, and finally the self-actualization needs in turn. ${ }^{1}$

Self-actualization needs are those needs that drive a person to achieve success in a variety of arenas. These needs are expressed in two motives, namely, competence and achievement. Hersey, Blanchard, and Johnson state that, "According to Robert W. White, one of the mainsprings of action in a human being is a desire for competence. Competence implies control over environmental factors - both physical and social. People with this motive do not wish to wait passively for things to happen; they want to be able to manipulate their environment and make things happen." ${ }^{2}$ However, people who have a low competence level are more likely to take fewer risks and therefore, are less motivated.

On the other hand the authors go on to suggest, "The high need for achievement surfaces only when people believe they can influence the outcome. Achievementmotivated people are not gamblers. They prefer to work on a problem rather than leave the outcome to chance."

The surveys that were conducted in three separate churches in the South England Conference show a close correlation between involvement in the local church ministries and that of knowing one's spiritual giftedness and being trained in identifying one's spiritual giftedness. Adding to this, it was clear that the vast majority of those surveyed

\footnotetext{
${ }^{1}$ Hersey, Blanchard, and Johnson, 36.

${ }^{2}$ Ibid., 47.

${ }^{3}$ Ibid., 48.
} 
expressed a desire for knowing their giftedness and being trained for greater involvement in the local church. This was not only among those who had no prior knowledge of their spiritual gifts, but also those who had previous knowledge of their spiritual giftedness and were already involved and active in local ministry.

In order to address this need it was necessary for me first of all to select one of the three churches in which the survey was conducted in order to pilot the strategy for greater involvement. The Gloucester Seventh-day Adventist Church was selected primarily because it is of a size that would act as a representative sample of the South England Conference churches. Secondly, in conducting the survey, there was a greater response to the questionnaire and many members expressed interest in receiving feedback. Thirdly, my relationship with the church is new enough to create the element of novelty which hopefully will generate greater cooperation. ${ }^{1}$

\section{Impact of Involvement}

A successful project will motivate the members to want to be involved in the ministries of the church for a number of reasons: (1) Members will have a sense of ownership of the activities, plans, and goals of the church. Because they are involved success or failure will be accredited to them. (2) The members will have a sense of fulfillment or accomplishment, in that they have contributed to the progress of the mission of the church. (3) Involvement will help to develop the character of the

${ }^{1}$ See appendix A for the Gloucester survey results. Note: No scores were recorded for questions 3,8 , and 12 because the data was no longer considered relevant to the project. No scores were recorded for questions 19 and 20 because responses were consistently "welcome it, enthusiastically," and "welcome it gladly." 
members. Working with others helps to shape and refine the graces that often go unpolished were it not for interaction with others. (4) Involvement lightens the load for everyone. (5) Members will find that there is less time to find fault with the church and with one another. Finally, (6) there will be greater growth seen as a result of a greater number of witnesses. 


\section{CHAPTER V}

\section{STRATEGY FOR THE MOTIVATION OF THE UNINVOLVED}

\section{CHURCH MEMBER}

The purpose of this project is to increase the number of members involved in local church ministries in order to help meet the challenges that confront the church in an ever changing world. However, to pursue this project it was necessary to identify the pilot church in which the project was to be tested. What follows is a brief profile of the Gloucester Seventh-day Adventist Church.

\section{Profile of the Gloucester SDA Church}

\section{A Brief History}

The Gloucester Seventh-day Adventist Church is situated in the town of Gloucester in the mid-western county of Gloucestershire, in rural England. The town boasts a population of almost one hundred and ten thousand, of which 49 percent are male and 51 percent are female. ${ }^{1}$ It has an average age of 37.5 and a majority age group of 30-59 years. Just over half of the town's population are either married or re-married, with over 28 percent who are single.

\footnotetext{
${ }^{1}$ www.neighbourhood.statistics.gov.uk. Data supplied by 2001 Census (1 December 2004).
} 
The dominant ethnic group of the town of Gloucester is Caucasian. Combined with the Irish population, there is a majority of more than 92 percent of the total population. The balance is made up of Asian and African-Caribbean, with less than one percent coming from the Oriental and other ethnic groups.

Living in the town of Gloucester makes one more likely to have a secure job than living in the average town or city in England and Wales, despite the fact that compared with these same countries, there are fewer retired residents and also fewer economically inactive students.

The Seventh-day Adventist Church in Gloucester is among the majority faith group of more than 74 percent Christian; however, of the remaining 26 percent, there are just over 14 percent who claim no religious affiliation.

The writer is indebted to the members of the Gloucester Church for the information on the history of their church. Reports have been compiled to commemorate special dedications of their place of worship over the years, and it is from this source that vital information will be extracted.

The Gloucester Seventh-day Adventist Church dates back to the year 1932 when the then district minister, John Bevan, pioneered the founding of a group of believers who were organized into a company within fours years with a membership of eighteen. Within thirteen years the company was organized into a church and on 12 March 1960 the members opened and dedicated their own church building on Cromwell Street in Gloucester. 
The Membership

The book membership of the Gloucester Church stands presently at $153^{1}$ with an average attendance of approximately 100. Despite the fact that the dominant ethic group in the town is white English and Irish, the dominant ethnic group of the church is AfroCaribbean. The majority is approximately 90 percent Black with a minority White population of just 10 percent. Of the majority population the predominant country of origin is Jamaica.

Over the past two decades there have been slight fluctuations in the profile of the membership of the church. Figure 5 illustrates the baptisms over the period. ${ }^{2}$

As can be seen from figure 5, during the decade of the eighties until 1992 there were very few gains in membership; however, a sudden increase took place from 1993 until 2000. Church Clerk figures show that over this period there was a total gain by baptism of 105 members, and only one gained by profession of faith.

${ }^{1}$ Data from South England Conference membership list, March 2005.

${ }^{2}$ Data taken from South England Conference Church Clerk reports, 8 March 2005. 
Gloucester SDA Church Gains:

Baptism/Profession of Faith, 1980-2004

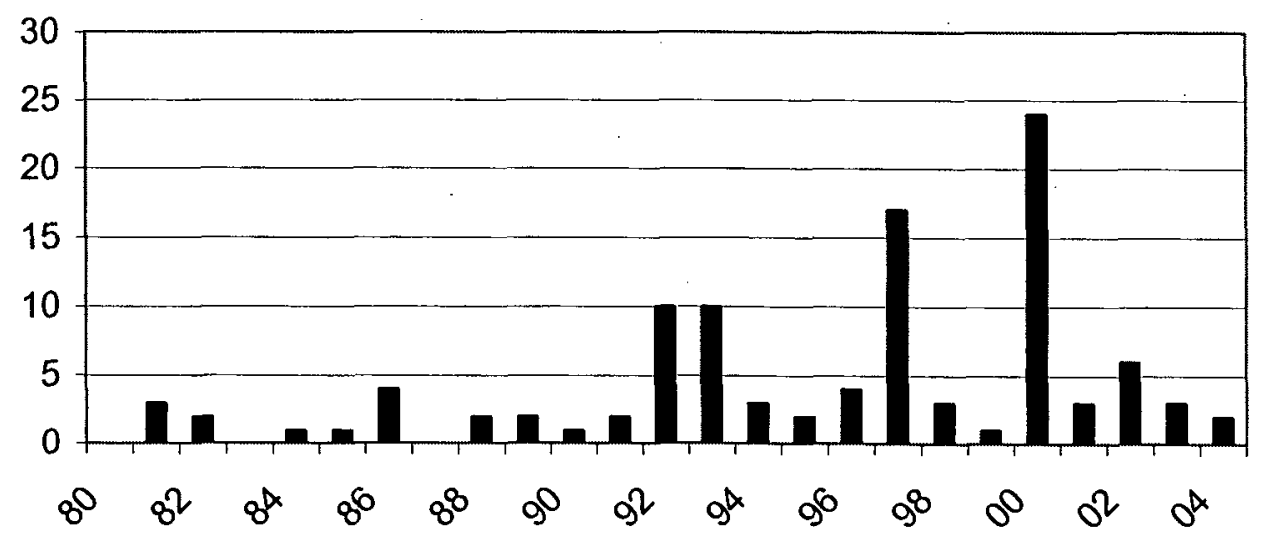

Figure 5. Gloucester Church Gains.

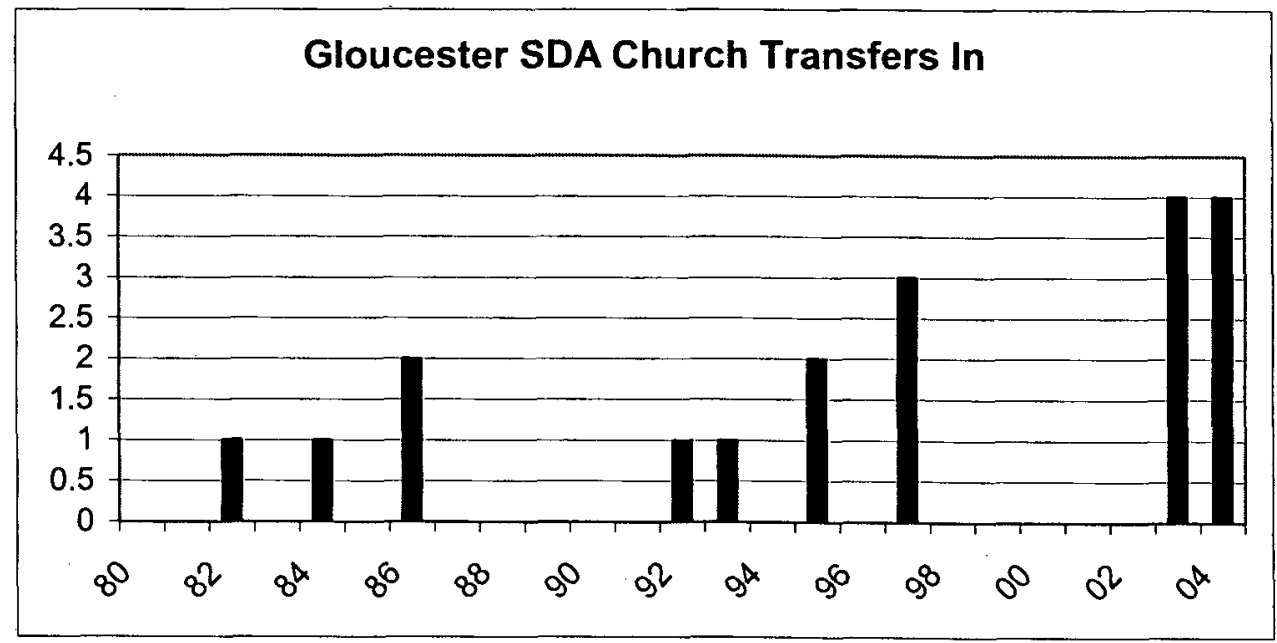

Figure 6. Gloucester Transfers. 
Gloucester has gained members also by transfers in from other Seventh-day Adventist churches. These have been churches found in the United Kingdom as well as churches in other parts of the world, namely, the Caribbean from where the majority of the membership have originated. The total number of transfers in has been nineteen (see figure 6).

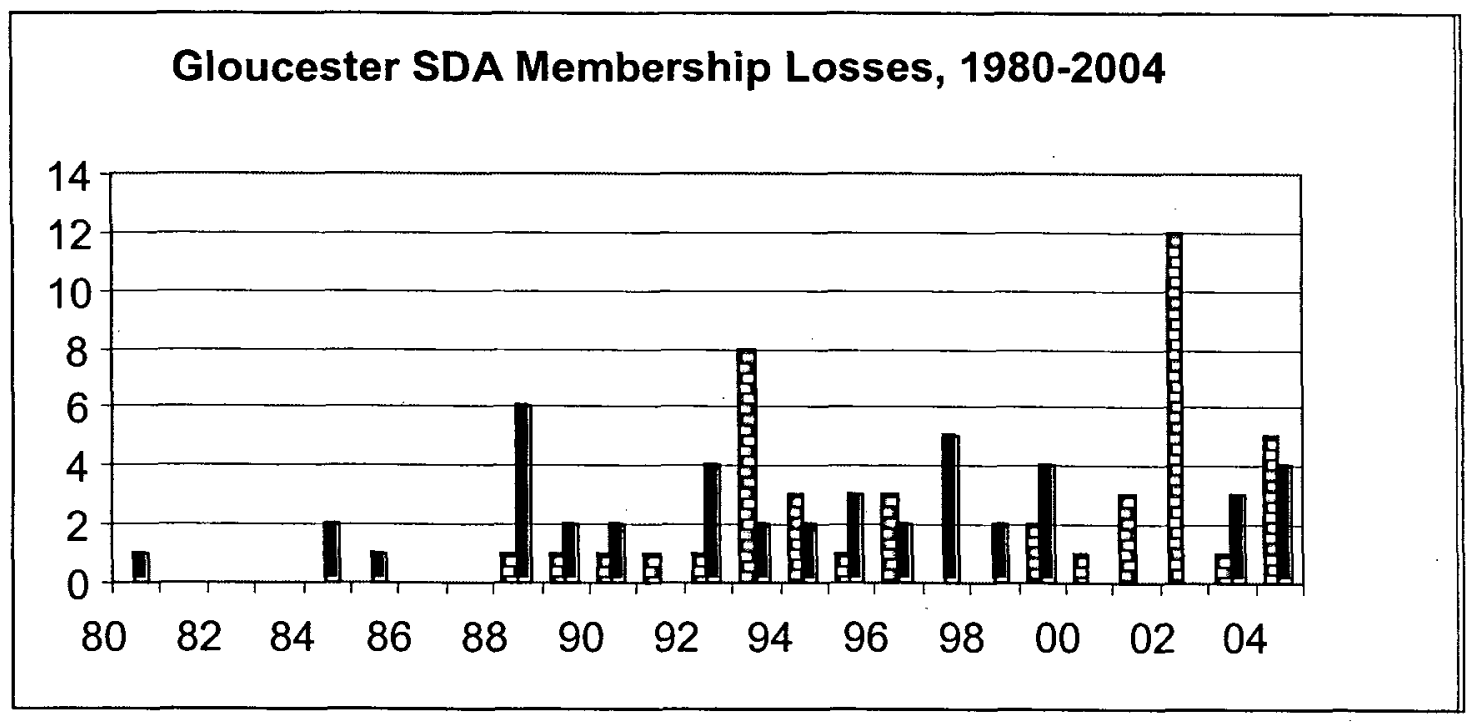

Figure 7. Gloucester Losses. Losses by Transfer 罩 Losses by Death/Apostasy

The church clerk's records show that the majority of losses due to transfers out of Gloucester were made to churches within the United Kingdom, whereas approximately one-third were transferred to churches in the Caribbean. The total number of losses for the period was eighty-nine members. As with many other rural churches in the South England Conference, Gloucester has lost many of its young adults to churches in the major cities of the United Kingdom, namely, Birmingham and Manchester in the north 
and London in the southeast. Many have left to engage in further studies and others for career purposes.

A survey conducted at the Gloucester Church indicates that the majority of its members are women who are keen to become more involved in ministry both inside and outside of the church.

The church is a fairly traditional church in that the ministries are all in line with those demanded by the administration at the South England Conference. The nominating committee recommendations for officers for 2005 do not indicate that there are any deviations or variations from main ministries expected of the majority of Seventh-day Adventist churches.

\section{The Worship Style}

The worship style of many Seventh-day Adventist churches throughout the British Isles had changed with the influx of West Indians; Gloucester's experience is not dissimilar. The West Indian conservative worship style was more liberal and more robust than the English conservative worship style. The English enjoyed a more contemplative worship experience, whereas the West Indians were used to a more responsive worship experience. In the African and West Indian community religion and worship formed part of the most important elements in the members' lives and the church building was symbolic of social strength and identity. Therefore when West Indians and Africans attended church in the morning, they were not intending to go home until the day was over and it became dark. When it came to worship the average English member found these changes to the established structure difficult to deal with. Many left and went to 
other churches and those who remained eventually grew old and died and were never replaced.

\section{Development of the Strategy for Involvement}

Self-awareness is a crucial factor in the motivation of lay members for active ministry. It is especially important in the areas of personality, temperament, worldview, passion, and knowledge of the will of God for the member's life. Failure to understand why they are who they are and why they do what they do, with all their likes and dislikes is a major cause of dissatisfaction and frustration on the part of many within the church community. The fact that Seventh-day Adventist Christians are called to engage in active ministry should be a catalyst in itself for greater effort toward understanding the will of God for their life, which includes understanding how God uses each Christian according to their personality and make up. These factors will play a crucial role in the development of the strategy to involve the inactive member.

To facilitate the process of planning and implementation of such a program it was necessary to prepare a Logical Framework, or "Logframe." The logframe is a project design tool intended to help structure and evaluate a project and to give guidance in carrying out each detailed phase of the project. It is a "systematic and visual way to present and share your understanding of the relationships among the resources you have to operate your program, the activities you plan, and the changes or results you hope to achieve." In other words, a logframe will show the relationship between your "planned

${ }^{1}$ See W. K. Kellogg Foundation, Logical Model Development Guide (Battle Creek, MI: W. K. Kellogg Foundation, updated 2004), 1. 
work" and your "intended results." The planned work includes the resources needed to carry out the project and the activities that one will be engaged in while carrying out the project. The intended results range from the immediate changes expected to the shortterm impact these changes will have on those who participate in the project directly and ultimately the long-term impact to those involved indirectly. Figure 8 is intended to clarify the process:

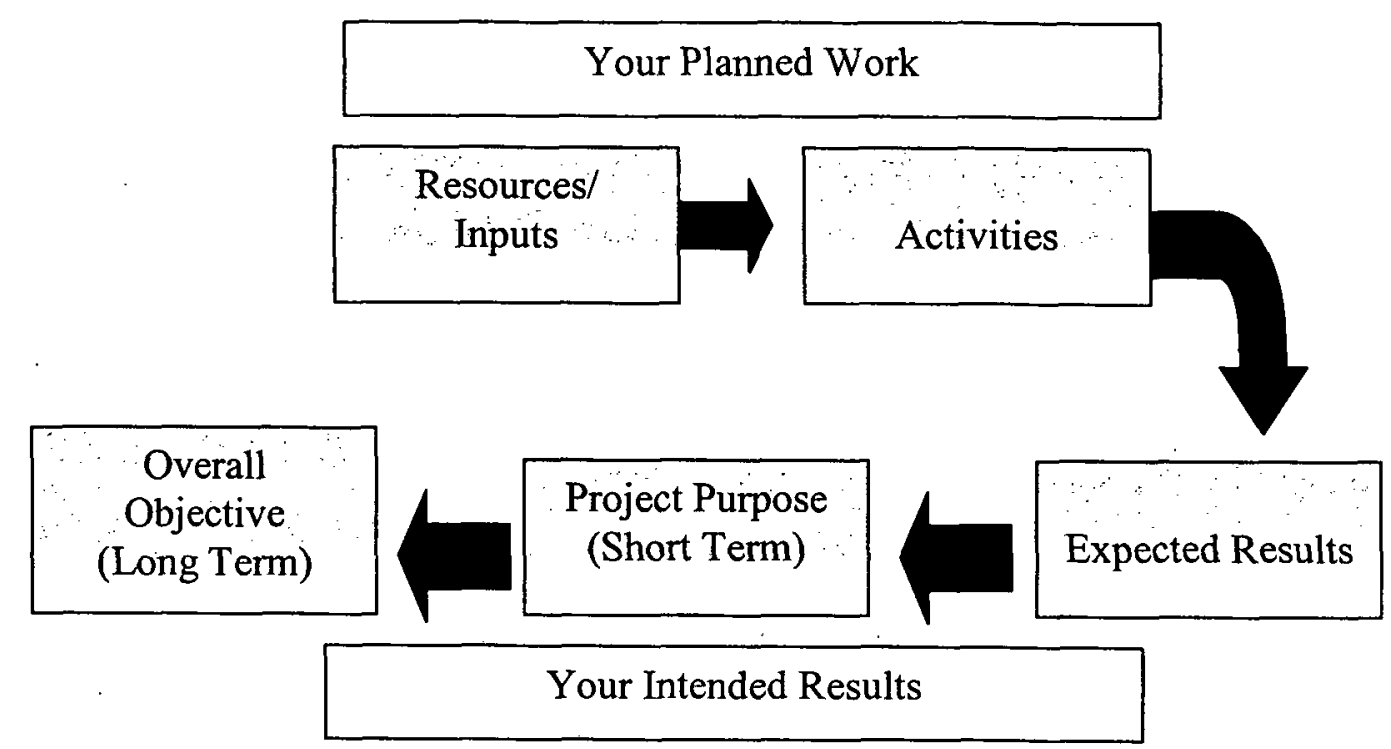

Figure 8: Reading a Logframe. Adapted from W. K. Kellogg Foundation, Logic Model Development Guide, 3.

In the above illustration the resources needed to carry out the project would include any financial inputs, materials for presentations, human resources such as assistants and presenters of seminars, and even the venue needed to carry out the

$$
\text { 1'Ibid., } 2 .
$$


activities. When all the resources are in place there is a greater likelihood that the planned activities will function more effectively and efficiently. The success of the planned activities is very much dependent on the availability of the resources.

The activities are the main part of the project. They may be varied and multiple but they all relate to each other and all contribute to the intended results. The activities form the hub of the project and must be well-thought through and well-executed. It may be only a short term activity, but if it is effective its contributions can be long-term.

The activities successfully accomplished will contribute to the outputs of the project. The output is the direct and immediate result of the project. This is necessary to show that the activities were not in vain. They are not accidental, but are planned. They are part of the strategy of the activities, and as a result of these outputs one is able to accomplish the direct purpose of the project: the immediate stakeholders will be benefited. This is the short-term result. The people for whom the project was intended are benefited. The benefits will, in turn, produce changes in the people and the environment in which the project was conducted and will ultimately accomplish the intended long-term goal of the project, that of influencing a wider community.

Appendix B shows the logframe matrix for this particular project. It is an outline of the strategy for the motivation of uninvolved church members in the Gloucester Seventh-day Adventist Church. The column headed "Objectives" is a description of the planned work and the intended results.

The two successive columns, namely the "measurable indicators" and the "means of verification," are analysis tools intended to clarify and realize the objectives. Their aim is to measure quantitatively and qualitatively the intended objectives and also to 
indicate the time frame in which these objectives are to be met. Quantitative indicators measure the number, size, and rate at which changes are expected to take place, whereas qualitative indicators measure the type or nature of the expected change.

The "important assumptions" in the final column serve to identify the necessary factors that need to be in place for each stage of the project to be successful. If these factors are not met then the project or activity in question cannot progress.

To further facilitate the execution and timing of the activities of the project it was necessary to construct a Gantt chart. This is a planning tool that is used by project managers to schedule tasks within a project so that the main activities can be completed within a given time frame. ${ }^{1}$

\section{Description of Strategy}

The overall objective or long-term goal of this project is ultimately to mobilize more church members to become involved in local church ministry. Emphasis is placed on the local church because it is my belief that the local church can be a hub of the community if the members are involved in making it a place for everyone to find fulfillment. It is unrealistic to expect all the members of the church to be involved in ministry, even though this is the ideal for all churches. However, my goal for this project is to see a minimum of 75 percent of the total membership involved in active ministry inside and/or outside of the church. Verification of this can be gained from the list of church officers compiled at the end of each year. If 75 percent are involved in the local

\footnotetext{
${ }^{\mathrm{I}}$ For the Gantt chart, see appendix C.
} 
church, this can provoke others to jealousy, and encourage them to be also trained for involvement.

The success of this phase of the project is dependent on the short-term purpose of the Gloucester church members being motivated to become more active in knowing who they are, what God has called them to be and do, and finally, that they can be equipped with the skills necessary for productive ministry. The aim is to increase by at least 10 percent the number of those who are presently involved in church ministries.

The strategy for the implementation of this project is three-fold. First, the resources, both material and human, needed for the project will be prepared. This includes all seminar materials, video and audio equipment, computer generated presentations, and inviting and securing guest lecturers who will make presentations on special subjects. Human resources also include the training of men and women who will mentor the uninvolved members. Second, the plan is to conduct training workshops that will (1) impart knowledge, (2) influence change, and (3) develop skills. Third, those members who have completed training will be mobilized into active ministry within the church. Mentors will have been trained who will monitor and encourage ongoing ministry. Close monitoring of and reporting by the mentors will ensure that the project is assessed by the project manager so that any difficulties can be addressed and all necessary adjustments made.

\section{Resources for Increased Knowledge}

In order for the uninvolved members to become actively involved on a long-term basis there needs to be an internal support system which will encourage and guide them into meaningful ministry. The method of internal support that this project will engage in 
will be a mentoring model. It is believed that if members within the Gloucester Church who are already actively involved and who are in a leadership position are able to mentor those who are uninvolved and are perhaps of less experience, then sustained support will be given to those who will need long-term motivation. The mentors themselves will also need to be encouraged and monitored on a regular basis to ensure that they do not become de-motivated in their tasks. This will be the responsibility of the project manager.

Even though the survey shows that many members claim that they were already aware of their spiritual giftedness it will be necessary to prepare resources on the subject in order to contextualize the other subject areas. It will be essential for the attendees to become aware of the uniqueness of each person in the utilization of their spiritual gifts, even though they may share their gifts with some other person. The need for this is echoed by James Arraj who, in discussing temperament type theories, states:

Jung developed a highly detailed yet flexible framework within which we can attempt to understand the legitimate differences among persons and the inner development they are called to. Certainly past spiritualities had no adequate way to deal with these differences. In practice, a uniform rule and prescribed spiritual exercises were often imposed in a mistaken quest for unity. We differ in our needs for food, sleep, and exercise. We vary in capacity for solitude and social life, and in our reactions to joy and sorrow. In short, we differ in our physical and psychic makeup and in our ways of perceiving and judging the world within and without. This means that we will be attracted to different forms of prayer and service, for our spiritual gifts will tend to build on the distinctive natural gifts we possess. ${ }^{\text {' }}$

The idea of utilizing spiritual gifts in the ministry of the church membership is by no means a new phenomenon. According to Christensen the writings of the apostle Paul on spiritual gifts in the ministries of the church imply that the early church had prior

'James Arraj, “Jungian Spirituality," Spirituality Today 40 (autumn 1988): 257. Quoted in Radmacher, 200. 
knowledge of, and were engaged in organizing the church according to the spiritual giftedness of the members. ${ }^{1}$ The strategy is to follow the example of the apostle Paul by instilling this knowledge of spiritual giftedness in the minds of the members as a means of motivation, and to alert the members to the realization of the benefits that spiritual gifts are to the church and to the ordained or professional ministry. It will be important for each member to note that the spiritual gift of pastoring, for example, was not given only to the ordained persons but more so to the laity, or to the church in general. If the spiritual gift of pastoring was recognized more in the church today it is very likely that fewer ordained pastors would suffer from burnout and other related set backs in ministry. ${ }^{2}$ Greg Ogden suggests, "Without denigrating the absolute necessity of leadership and its catalytic nature, the biblical emphasis is not on the 'omnicompetent' pastor, but on the multigifted body. Jesus Christ was the only fully gifted human, and when he ascended to his Father, he chose to create an interdependent, multifaceted, corporate body as the only entity that could contain his gifts. No individual was ever meant to show the fullness of Christ to the world. We are meant to do that through redeemed communities."3

Even though the training will involve the identifying of spiritual gifts it will be stressed that the job of identifying spiritual gifts must lie with the entire church community. There is a role for the pastor/leader, the leadership team, and also the

${ }^{1}$ Christensen and Savage, 106.

${ }^{2}$ Ibid., 109.

${ }^{3}$ Greg Ogden, The New Reformation: Returning the Ministry to the People of God (Grand Rapids, MI: Zondervan Publishing House, 1990), 75. 
congregation at large. It says in 1 Cor 12:7 that spiritual gifts are given to all, for the benefit of all, and therefore no one should be tempted to suggest that they do not possess a gift. "To deny that you have one or more spiritual gifts is to deny part of the creative work of God in the world. Gifts have no automatic ties to your educational or socioeconomic level or profession. Gifts are not limited by race, ethnic background, gender, or sexual orientation."

Another part of the strategy for increased knowledge is to assist the mentors and uninvolved members in exploring their personality type. Helping them to understand why they are who they are will help them to put their spiritual gifts into perspective and learn to identify their natural ability and calling.

Understanding personality type can be quite complex and difficult to define. According to Robert Ewen, psychologists have difficulty finding a generally accepted definition for personality. ${ }^{2}$ However, he concludes that "personality refers to important and relatively stable aspects of a person's behavior." ${ }^{33}$ The aim in this strategy therefore, is that each person should be able to understand his or her own stable and regular behavior, thus better being able to assess the reasons for their actions and better able to determine their natural responses to certain stimuli and tasks.

There are a variety of tools available for assessing personality types; however, the tool that will be employed for this project will be one that is based on the Meyer-Briggs

${ }^{1}$ Christensen, 116.

${ }^{2}$ Robert B. Ewen, An Introduction to Theories of Personality (Mahwah, NJ: Lawrence Eribaum Associates, 1998), 3.

${ }^{3}$ Ibid. 
Type Indicator and combines leadership and management studies conducted by Hersey and Blanchard with studies in the behavioral sciences and psychology. The tool is based on the "DISC" theory and is produced by an international company called "Extended Disc."

The "DISC" theory's name is based on the four basic personality types identified by William Moulton-Marston in the 1920s. " $D$ " (dominance), describes a person who is aggressive, determined, has a pioneering attitude, and may even be perceived as being stubborn. "I" (inducement), describes one who is persuasive, charming, winsome, and influencing others. "S" (submission) describes a person who is calm, good natured, obedient, and altruistic. "C" (compliance) is for someone who has an appreciation for beauty, is peace loving, shy, and adaptive, among other similar descriptions. ${ }^{1}$

The tool's purpose is to assess personality types of individuals in the context of their comfort zones and their working environment. The test highlights and illustrates the fact that individuals will adjust their behavior according to circumstances and may not be aware that they are doing so and why. The "personal analysis" tool personally analyzes each individual and gives a computerized profile of their perceived strengths, areas of needed development, and how best they can conscientiously relate to their working environment. An advantage of this test is that it helps the participant to identify which types of work and responsibilities demand greater energy to perform. Not only does it identify types of work but also other types of personalities which are incompatible or demand excessive energy. The greater the amount of energy needed, the less likely they

\footnotetext{
${ }^{1}$ See Extended DISC (UK) Ltd., Extended DISC System User's Manual, Personal Analysis/Team Analysis, (n.p.: Extended DISC (UK) Ltd., 2003), 10.
} 
are to feel comfortable doing the task long-term. Within the context of the church and local ministries, this information is vital for the member to feel fulfilled and accomplished. The test can be administered electronically via the internet, or manually, in written form.

\section{Performance Objectives}

There are certain performance objectives that are necessary for each seminar to be effective. These objectives must be identified in order to help in the assessment of the overall project. In the "increase of knowledge" seminars the objectives are first of all for the participants to be able to recall the knowledge that has been passed on to them. This is important to assure that the information is valued and not dismissed by the participants. To do this one needs to give opportunity for discussion of the material, maybe in a simple question and answer session where the information previously received can be "regurgitated" to some degree and any clarification that needs to be made can be made.

It will also be necessary for each participant to show evidence that the imparted information from the seminar is understood. This is obviously an important objective that can be assessed through the responses of the participants and by allowing time for, and encouraging any questions that may arise from each of the seminar presentations. This objective leads naturally to giving opportunity for each participant to demonstrate, with the assistance of the presenters, the application of the information to their own situation and lives.

The next objective is that of analysis of the information. Does each participant know why this information is important? What is the importance to their particular situation, giftedness, and personality type? These questions, and others, must be 
answered by the participants to enable them to synthesize the knowledge and allow it to become part of their thinking and regular activities.

The final objective will be for the participants to assess the knowledge they have received to determine whether it is relevant to them.

\section{Resources for Change of Attitude}

The seminar in "change of attitude"' is a strategy for change in the participant's motivation toward involvement in the local church. The aim is to develop in the participants a positive attitude concerning involvement in the work of the local church and to create a sense of willingness to be proactive in creating opportunities for ministry. The resources for this seminar were power point presentations and handouts for each participant on Core Values Audit adapted from Aubrey Malphurs', Advance Strategic Planning. ${ }^{1}$ Each participant completes the audit after the presentation on "change of attitude" and then shares their conclusions with the rest of the participants.

\section{Performance Objectives}

The performance objectives of the change in attitude seminar are first of all to bring each participant to the point of giving God their attention. This means that each participant will become aware of the fact that God has a purpose and a ministry for each person, and then to recognize the need to seek an understanding of God's values. This will take the form of spiritual instruction and will lead to the second objective of response and participation in actively discovering the values of God through Bible study, prayer,

${ }^{1}$ Aubrey Malphurs, Advanced Strategic Planning: A New Model for Church and Ministry Leaders (Grand Rapids, MI: Baker Books, 2000), 236. 
meditation, and fellowship. Discovering God's values takes place over time. It is through continuous study of the Bible that one identifies the values that God holds dear. God's values are revealed in seeking to understand the principle that governs God's interactions and commands as found in Scripture.

Once God's values have been explored it then becomes necessary to accept God's values in light of organizing one's own value system. The organizing of one's values must be a result of comparing God's values with one's own. Personal deficiency will be amplified in the light of God's sufficiency. Organizing may mean discarding certain long held traditions and identifying certain priority values that may need immediate attention.

The vision of God's values must be a motivator for ministry in each of the participants. This motivation must ultimately lead to the participants characterizing the values of God, namely, adopting a new way of life.

\section{Development of Skills}

The final seminar will be in the development of skills for increased participation in the local church ministries. It is necessary to guide the participants in how they can actively become involved in ministry. This will involve the sharing of ideas and models that others have used and have proven successful. It will mean accepting the fact that not all ministries can practically be engaged in without certain adjustments being made in the local church structure and philosophy of ministry and mission.

At this stage of the strategy it will become necessary for the mentors and mentees to become aware of their responsibilities. Instruction will be given on how mentees can observe the mentors and other leaders doing ministry in their respective area of 
giftedness, with the view of preparing themselves to be active participants. After observation comes active participation with assistance from mentors and other leaders.

\section{Mobilizing Members for Ministry}

At the conclusion of the seminars the next, and perhaps the most important stage of the strategy, is to mobilize the participants for ministry. At this stage the role of the mentors comes into play. The mentor's role will be to guide, counsel, and encourage the mentee as he or she participates in ministry. The long-term objective will be for the mentee to be fully engaged in ministry without assistance, and this time frame will differ for each individual. With continued participation and practice ministry will become habitual and the mentees will in turn become mentors to others who are developing in the local church.

The mentor-mentee relationship after the seminars will be crucial in determining the sustainability of the project. If the mentoring program breaks down and the mentees become de-motivated then the project's objective will be lost. It is therefore necessary to establish and implement a network support system that will monitor the on-going effectiveness of the mentors-mentee relationships. This must include initial weekly meetings between mentors and mentees for prayer, feedback, and encouragement. They may even be free to develop the meetings into deeper relationships for ministry on an ongoing basis. The support network will also include regular contact between the mentors and the project manager, incorporating at least a monthly meeting for dialogue and assessment of the program. 


\section{Implementation Strategy}

It was anticipated that the implementation of this project take place over a period of approximately four months. This included initial meetings with stakeholders, preparation and securing of all resources, conducting the training sessions, and finally evaluating the project.

The implementation strategy began with first realizing the need to speak to the pastor and board members of the Gloucester Seventh-day Adventist Church. The purpose of this meeting.was to share my plans with them and secure the blessing of the church board for me to conduct this pilot project with the members of the church. This was done on the evening of 4 September 2004. The board members were very accommodating. After sharing with them the details of my logical framework they asked questions of clarification such as to whom the program would be targeted, what the cost would be to the church, and whether the program would be sponsored by the Conference or if it was my personal project. Comments were also made that gave affirmation of the need for this type of project to be conducted in the Gloucester Church. The general consensus of the verbal comments from those in attendance was that 75 percent of the membership was uninvolved and therefore, this would be a welcomed project. After discussion and questions answered, the pastor called for a motion to accept the recommendation and it was voted unanimously.

The next phase of the implementation strategy was to present the training plans to the church members and also to meet the leaders and members who are involved in local ministry and who will be trained as mentors. 
In presenting the project to the members it allowed opportunity for those who felt the need for more involvement to participate in the training. This way they retained the right to volunteer rather than be enlisted by the leadership of the church. To allow for a level of anonymity it was necessary to prepare a response slip for each member to use, should they choose to. This was distributed during a Sabbath morning service, explanation was given on how to complete the response slip and they were collected at the end of the service. The response slip read as follows:

\section{Motivation of Uninvolved Church Members Gloucester SDA Church}

"I am not involved in local ministry as I would like to be and I would like to enroll for the special training for uninvolved church members."

Name:

Address:

More information will be sent to you giving detail of venue, dates, etc. Thank you for your cooperation.

Figure 9: Response Slip.

There were twenty-eight responses from the membership indicating that they wanted to be involved in the training project for uninvolved members. Having received the responses I then consulted with the local pastor to verify whether all the responses were, in fact, uninvolved members. Fourteen were identified as being uninvolved.

The meeting with the prospective mentors was necessary in order to share with them the philosophy, not only of the project, but of mentoring itself. Seven persons were 
selected by the church board to be mentors. These were leaders who were actively involved in the local church and who the board thought could give spiritual guidance. It was necessary to meet with them because it was possible that some leaders would not have had the time to mentor others, and others might not understand the importance of the commitment that is required on the mentor's part for a successful outcome to the project. It was necessary to point this out to each of them and to secure the commitment of each person to first of all participate in the training and then to be part of the mentoring process.

After the initial meetings with the various committees it was necessary to arrange a series of dates for starting the seminars. These dates were arranged around the church's evangelistic and regular scheduling.

The first seminar conducted was on personality types. It was conducted on 4 December 2004. The sermon preached to the congregation on that Sabbath morning was on the theme, "God uses ordinary people to touch ordinary lives in extraordinary ways." This was followed by the seminar in the afternoon on personality types.

There were approximately twenty participants at the seminar. A presentation on personality type was conducted, followed a by personal analysis profile questionnaire being completed by each participant. All questionnaires were taken away and computer analyzed. After correction of some incorrectly filled in questionnaires, within four weeks, the results were shared with those who participated. As a result of word-ofmouth, many new members who were not present at the first session attended the second session of the seminar and requested that their profiles be done also. This was done while the results of the first session were shared with those who were waiting for their 
scores. An important objective of this series of seminars is to help each member identify their personality type and then explain it to someone else. This was done by all participants with someone who they knew well. That person then confirmed as to whether they identified those characteristic in the participant.

All those who attended the personality seminar and also filled in the questionnaire were asked to fill in an evaluation sheet. The results indicated that the participants underwent a positive learning experience and were motivated to become more involved in ministry.

The next seminar was on identifying one's Spiritual Gifts. This was conducted on 2 April 2005. Many members had already completed a Spiritual Gifts inventory and were aware of their Spiritual Gifts-this is verified by the survey conducted in the church (see appendix A). However, some completed a questionnaire and were able to identify their spiritual giftedness. Approximately twenty persons attended this seminar.

The next and final seminar for the uninvolved member was the "change of attitude" seminar which was conducted on 23 April. Again approximately twenty persons attended. The seminar included information on how to become aware of one's values and how they relate to our attitude. An exercise was conducted that helped to explore God's values. After this the attendees completed a worksheet which helped them to explore their own values (see appendix C) and then to compare them with God's values. Those in attendance completed an evaluation sheet and the results and comments indicated a positive learning experience. 


\section{Impact of Lay Involvement}

When church members are more involved in local ministries they are better able to identify the spiritual gifts that they may be blessed with. It is only in ministering that they are able to expose themselves to the variety of opportunities that await them in the services of the church. Exploring opportunities for ministry will help to satisfy the need to aspire to new goals and challenges. Everything that the members try may not be the right ministry, but in the process the conviction and the direction of their calling will be made clearer.

Christians cannot over-estimate the influence that they have over those who are in their community. Ministry involvement motivates others to be involved even though it may not be the Christian's primary intention. Ellen White states, "Every act of our lives affects others for good or evil. Our influence is tending upward or downward; it is felt, acted upon, and to a greater or less degree reproduced by others. If by our example we aid others in the development of good principles, we give them power to do good. In their turn they exert the same beneficial influence upon others, and thus hundreds and thousands are affected by our unconscious influence."1

As church members continue in local ministry they not only become more aware of their spiritual gifts and influence on others, they also develop and sharpen the skills that have perhaps lain dormant for years, and which may have never been used.

Therefore the member becomes a great asset to the church and experiences a greater sense of usefulness as they are made more aware of their true potential for ministry.

\footnotetext{
${ }^{1}$ Ellen G. White, Testimonies for the Church, Vol. 2, (Boise, ID: Pacific Press, 1948), 133.
} 
The impact of lay involvement is not only felt in the life of the church member and the local church, it is also felt in the wider Adventist community. A project of this sort, successfully run, can be replicated in neighboring churches and eventually to neighboring communities. If local pastors see the benefit of such a model for lay involvement it is something that will become a permanent part of their strategy for lay training and mobilization. 


\section{CHAPTER VI}

\section{CONCLUSION}

\section{Summary}

The purpose of this project has been to highlight the need among local church members for more active involvement and to suggest and implement a strategy for reintegration of the uninvolved member into greater involvement in the main program and mission of the local church. The local pastor and leaders of the Gloucester Seventhday Adventist Church were convinced that this project would be of benefit to their church, so they agreed to allow their church to be used for the implementation of the project strategy. The project started with the holding of a series of seminars with those who had expressed a desire to become more involved in their local church ministries. The aim was to convince each uninvolved member that an understanding of their personality type, knowledge of their spiritual giftedness, and a change of attitude toward their own values would give them a greater sense and appreciation of their mission in the local church context.

The original plan was to conduct the seminars over a period of one weekend; starting on a Friday and finishing on a Sunday evening. However, funding for the project was not forthcoming and this created certain obstacles, namely: (1) guest speakers could not be invited to present specialized subject material such as spiritual gifts, mentoring, 
and personality types, and (2) plans to hire a residential venue for the weekend seminars could not be pursued.

As a result of the funding crisis, at a meeting with the leaders of the Gloucester Church, it was decided that the time frame for the seminars be extended to take place over a period of four to five months, to conduct the seminars on Sabbath afternoons and to use the church building as the venue. This would obviously mean that there would not be a captive group. Familiarity of the church building would become a deterrent and the Sabbath afternoon meeting would prove some difficulty, especially in trying to attract the uninvolved church member who is already unmotivated.

\section{Lessons Learned}

As a result of planning and conducting the seminars for the uninvolved church member there were certain findings or lessons that were learned, which will be shared as follows:

1. Getting uninvolved members to register for the seminars was a challenge. It would appear that most uninvolved members need a personal invitation to participate. A disadvantage of not knowing the membership is that one cannot identify the uninvolved before hand. This prior knowledge of the membership would have been crucial in extending specific invitations to specific people.

2. Involved members were eager for more training. Registration slips suggest that they want to be more involved than they already are. This might also suggest that they are not involved in the areas of their giftedness. This revealed that the materials presented in the seminars served a dual purpose in that both involved and uninvolved members were benefited. 
3. Members expressed concern that they had already been trained in these areas but nothing had come of it-it had made no difference. This made it incumbent that this project be carried through to its final conclusion.

4. The local pastor observed that conducting the seminar away from the church building would prove difficult. This was due to some members' unwillingness to commit themselves to the time demands for them to be away from family and the local church. In the future, more long-term planning with the members could overcome this problem.

5. It is necessary that this project be conducted by the local leadership in their local church setting. Local leadership have knowledge of the members and have greater control of resources.

The final stages of the project include the training of the mentors and the mobilization of the uninvolved members. Time and circumstances have not allowed for this to take place up to this time. However, an observation that has been made is that the ministries of the local church will need to be further explored and restructured in order to accommodate the anticipated demands of a more motivated and involved membership. The traditional departmental structure of the churches in the South England Conference is not conducive to innovation from motivated members and anyone who would like to become involved in an unconventional or a supporting ministry.

Another observation is that the mentors would not be empowered to implement changes to the local church structure that may be necessary to accommodate all members who would want to engage in a ministry that is not offered by the present church structure. This is something that the local church board will need to become conscious of and implement measures to bring about whatever changes that will be thought necessary. 
For this reason then, it is vitally necessary for a project such as this to be conducted, managed, or endorsed by the local church leadership. Local church leaders are at an advantage of knowing the membership and are therefore better able to identify those members who may be invited to participate in the training and seminars. Local leaders also have a greater control over local finances and are able to command budgets to run such a project.

The successful training of the mentors provides for a potential ministry in itself, in that it is not a one-time activity; but rather, it is something that will be ongoing for as long as there are members who need to be motivated. The training equips them to work with groups of uninvolved members or with individuals, and their role will be seen as key to the ongoing growth and development of the church growth strategy for local churches.

One dilemma encountered during this project was where to schedule the training of the mentors. It was originally planned to conduct the training at the start of the project, prior to the increase of knowledge seminars. The thinking was that mentors would need to be ready to implement the training as soon as the members were ready. However, it was also felt that the mentors needed to be aware of the training and information that the members were receiving and that the information could be something that could be of benefit to them also. For this reason it was decided to conduct the training for mentors after all other seminars had taken place. In hindsight, it is felt that this was a mistake.

\section{Recommendations}

Time has not allowed for the completion of this project prior to presentation of this paper. In light of this a meeting was held with the Gloucester Church board on 
5 June 2005, in order to share the findings from the project and to present recommendations to the board for the future involvement of church members in ministry. The presentation to the church board emphasized that the strategy was to:

1. Show members the importance of personality types and its relationship to ministry.

2. Help members understand the importance of spiritual gifts and its relationship to ministry.

3. Train mentors to identify needs of uninvolved members and encourage and support them in development of their involvement.

4. Mobilize members into ministry.

Observations:

1. Fifty percent of regular members have been assigned responsibilities or to ministries.

2. Not all involved members have been assigned to ministries in line with their giftedness.

3. Some involved members are dissatisfied with their level of involvement.

4. In order for the training to be effective certain changes will need to be made to the structure of the church for ministry.

5. Trained mentors would not have authority to implement necessary changes.

Recommendations:

1. That the church board give study to the present ministry structure of the church and recommend and implement necessary changes to facilitate greater involvement of members. 
2. That the church board give study to helping each member to have a clear understanding of the mission strategy of Gloucester Church.

3. That each church board member be trained as mentors for uninvolved church members.

4. That the church board compile a database of the spiritual giftedness and personality profile of each of the members of Gloucester Church.

5. That the church considers implementing the Natural Church Development strategy for long-term natural church growth and member involvement.

The church board voted to accept the recommendations and to allow the project to continue for an indefinite period. 
APPENDIX A

\section{Church Involvement Survey Results}

Gloucester Results. Participants: 59 Persons

Dear Church Member

I am conducting a survey of members of the church to determine why we are or are not involved in our local church ministry. Your help in this research will be vital to the development of a strategy for the motivation of lay members for local church ministry. Please respond to each question as honestly and thoroughly as possible. Thank you very much for your assistance and God bless you.

Michael G. Hamilton

1. Which age group do you belong to?

$\underline{\text { Results }}$

- $15-20$

- $21-25$

[ 4 ]

- $26-30$

- $31-40$

- $41-50$

- $51-60$

- $61+$

2. Are you male or female?

Male [13] Female [26]

3. Which area of the South England Conference is your church located in?

- [ ] Area 1 (Devon/ Cornwall)

- [ ] Area 2 (Somerset/ Gloucestershire/ Wiltshire)

- [ ] Area 3 (Hampshire/ Dorset)

- [ ] Area 4 (Kent/ Sussex) 
- [ ] Area 5 (Berkshire/ Buckinghamshire/ Oxfordshire/ Surrey)

- [ ] Area 6 (Greater London)

- [ ] Area 7 (Bedfordshire/Hertfordshire/Buckinghamshire)

- [ ] Area 8 (Cambridgeshire/Essex/Suffolk/Norfolk)

4. For how long have you held membership in your local church?

- Less than 2 years

- $\quad 2-5$ years

- $\quad 5-10$ years

- $10-15$ years

- $\quad 15-20$ years

- $\quad$ More than 20 years

5. How many hours per week do you spend in ministering to the church members?

- $\quad 0-1$ hour

- 1-3 hours

- 3-5 hours

- $\quad$ more than 5 hours

6. How many hours per week do you spend ministering to the 'unchurched' (those outside the church)?

- $\quad 0-1$ hour

- 1-3 hours

- 3-5 hours

- $\quad$ more than 5 hours

7. Do you know what your spiritual gift(s) is/are?

- Yes

- No

- $\quad$ Not Sure

8. What area(s) of ministry do you consider yourself to be most gifted in? 
- [ ] Youth Ministry

- [ ] Evangelistic Ministry

- [ ] Teaching Ministry

- [ ] Administrative Ministry

- [ ] Other (Please specify)

9. Have you ever had help in identifying your spiritual gift(s)?

- $\quad$ Yes

- $\quad$ No

- Not Sure

10. Have you ever had training in how to share your faith, or work in the local church?

- $\quad$ Yes

- $\quad$ No

- Not Sure
[ 4 ]

11. If you have never attended training, what reason can you give for not attending?

- I couldn't afford the time to go

- I didn't think the training would be effective

- Training was never offered for my area of ministry

- I just couldn't be bothered

- $\quad$ Other (Please specify)

12. If you have had training, what area(s) of ministry were you trained in?

- [ ] Youth Ministry

- [ ] Evangelistic Ministry

- [ ] Teaching Ministry

- [ ] Administrative Ministry

- [ ] Other (Please specify)

13. If you have attended training, what reason did you have for attending?

- My church said that I had to go 
- I wanted to become better equipped to serve in the church [31]

- I just went along for the experience [ 4 ]

- Other (Please specify)................................................ [ ]

14. Have you been involved in the area(s) of ministry that you were trained in?

- Yes

- No

- $\quad$ Not sure

15. If you have had training and are not actively involved in your local church ministries, what reasons can you give for not being involved?

- No opportunities in your local church

- Lack of motivation to be involved

- Fear of failure

- $\quad$ Fear of trying

- The ministries offered are not in accordance with your training $\quad[0]$

- The ministries offered are not in line with your spiritual gift(s) [ 1 ]

- $\quad$ Other (Please specify)

16. To what degree are you involved in your local church?

- $\quad$ Very involved

- Occasionally involved

- Hardly ever involved

- $\quad$ Never involved

17. Which statement best describes your attitude about church involvement?

- I am very involved in my local church and am enjoying it.

- I am involved in my local church but am not enjoying it.

- I want to be involved in my local church but don't know how.

- I don't want to be involved in my local church.

- I wish I were more involved in my local church. I wish someone would ask me 
to do something.

18. If you were to become more efficient in your ministry in your local church, what would you consider to be your greatest need?

- A better understanding of your roll in the church

- A greater commitment on your part to become involved

in your local church

- More efficient training to prepare you to become more involved

- More opportunity to be involved in your local church

- $\quad$ Other (Please specify)

19. If you were offered help in identifying your spiritual gift(s), would you:

- [ ] Welcome it, enthusiastically?

- [ ] Welcome it, but not right now?

- [ ] Think that it is a waste of time?

- [ ] Think that it is a good idea, but not for me?

20. If you were offered training in how to be involved in your local church, would you:

- [ ] Welcome it, gladly?

- [ ] Welcome it, but not right now?

- [ ] Think that it is a waste of time?

- [ ] Consider it a good idea, but not for me?

Please return this immediately after you have completed it. May God bless you. Thank you once again. 


\section{APPENDIX B}

\section{Logical Framework for Motivating Uninvolved Members for Ministry}

\begin{tabular}{|c|c|c|c|c|}
\hline & OBJECTIVES & $\begin{array}{l}\text { MEASURABLE } \\
\text { INDICATORS }\end{array}$ & $\begin{array}{l}\text { MEANS OF } \\
\text { VERIFICATION }\end{array}$ & $\begin{array}{l}\overline{\text { IMPOI }} \\
\text { ASSU! }\end{array}$ \\
\hline $\begin{array}{l}\text { OVERALL } \\
\text { OBJECTIVE }\end{array}$ & $\begin{array}{l}\text { To mobilize more uninvolved members } \\
\text { to become involved in local church } \\
\text { ministries }\end{array}$ & $\begin{array}{l}75 \% \text { of members } \\
\text { involved in local church } \\
\text { ministry }\end{array}$ & $\begin{array}{l}\text { Departmental Register } \\
\text { of members } \\
\text { involvement }\end{array}$ & $\begin{array}{l}\text { Pastor } \\
\text { adopt } \mathrm{F}\end{array}$ \\
\hline $\begin{array}{l}\text { PROJECT } \\
\text { PURPOSE }\end{array}$ & $\begin{array}{l}\text { Number of members motivated for } \\
\text { involvement in local ministries } \\
\text { increased }\end{array}$ & $\begin{array}{l}10 \% \text { increase of } \\
\text { involvement in local } \\
\text { church ministries } \\
\text { within first year }\end{array}$ & $\begin{array}{l}\text { Training register and } \\
\text { activity record of } \\
\text { mentors }\end{array}$ & $\begin{array}{l}\text { Pastor } \\
\text { willing } \\
\text { progral }\end{array}$ \\
\hline \multirow[t]{3}{*}{$\begin{array}{l}\text { EXPECTED } \\
\text { RESULTS }\end{array}$} & 1. Resources Produced & $\begin{array}{l}\text { Seminars materials and } \\
\text { other resources } \\
\text { completed by } \\
\text { November } 2004\end{array}$ & Seminar materials file & $\begin{array}{l}\text { Humar } \\
\text { training } \\
\text { availat }\end{array}$ \\
\hline & 2. Members Equipped & $\begin{array}{l}\text { All complete Seminars } \\
\text { by December } 2004\end{array}$ & $\begin{array}{l}\text { Register of Certificates } \\
\text { issued }\end{array}$ & $\begin{array}{l}\text { Mento } \\
\text { be trair }\end{array}$ \\
\hline & 3. Members Involved & $\begin{array}{l}\text { All trained members } \\
\text { assigned to local } \\
\text { ministry }\end{array}$ & $\begin{array}{l}\text { Trained member } \\
\text { involvement record }\end{array}$ & $\begin{array}{l}\text { Leader } \\
\text { envirol } \\
\text { ministr }\end{array}$ \\
\hline ACTIVITIES & $\begin{array}{l}\text { 1.1 Develop Training Resources } \\
\text { 1.1.1. Mentors Training Manual } \\
\text { 1.1.2. Spiritual Gifts Manual } \\
\text { 1.1.3. Personality Test Manual } \\
\text { 1.2. Develop Human Resources } \\
\text { 1.2.1. Rehearse Seminars } \\
\text { 1.2.2. Train Mentors } \\
\text { 2.1. Promote need for training } \\
\text { 2.1.1. At church board } \\
\text { 2.1.2. With mentors } \\
\text { 2.1.3. With members } \\
\text { 2.2. Conduct training workshops } \\
\text { 2.2.1. For Mentors } \\
\text { 2.2.2. "Increase of Knowledge" } \\
\text { 2.2.3. "Change of Attitude"" } \\
\text { 2.2.4. "Skill Development" }\end{array}$ & 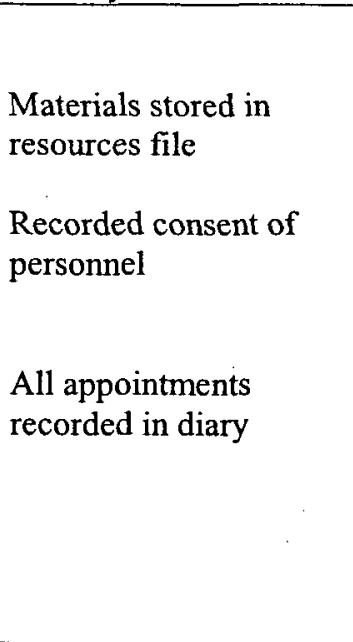 & $\begin{array}{l}\text { Invitation from local } \\
\text { Pastor } \\
\text { Venue secured and } \\
\text { invitations extended } \\
\text { and accepted }\end{array}$ & $\begin{array}{l}\text { Funds } \\
\text { availat } \\
\text { necessi }\end{array}$ \\
\hline
\end{tabular}


Logical Framework-Continued.

\begin{tabular}{|c|c|c|c|c|}
\hline & OBJECTIVES & $\begin{array}{l}\text { MEASURABLE } \\
\text { INDICATORS }\end{array}$ & $\begin{array}{l}\text { MEANS OF } \\
\text { VERIFICATION }\end{array}$ & $\begin{array}{l}\text { IMPOI } \\
\text { ASSUI }\end{array}$ \\
\hline ACTIVITIES & $\begin{array}{l}\text { 3.1 Mobilize Members for Local } \\
\text { Ministries } \\
\text { 3.2. Establish Network Support } \\
\text { System } \\
\text { 3.2.1. On-going mentoring and } \\
\text { support } \\
\text { 3.2.2. Weekly meeting with } \\
\text { members } \\
\text { 3.2.3. Spiritual support }\end{array}$ & $\begin{array}{l}\text { Members assigned to } \\
\text { department } \\
\text { Record of meetings } \\
\text { held }\end{array}$ & $\begin{array}{l}\text { Record of mentor's } \\
\text { interaction with trained } \\
\text { members }\end{array}$ & $\begin{array}{l}\text { Mentor } \\
\text { membe } \\
\text { to parti } \\
\text { follow. }\end{array}$ \\
\hline
\end{tabular}




\section{APPENDIX C}

(Activity Schedule Inserted) 


\section{APPENDIX D}

\section{A Personal Core Values Audit}

An adaptation from Advanced Strategic Planning by Aubrey Malphurs.

Please indicate what your personal core values are by rating each of the core values from 1 to 5 ( 1 being the lowest and 5 being the highest). Give as fewer $5 \mathrm{~s}$ as possible. Do not be too analytical. Work through as quickly as possible, going with your first impression. Please feel free to add to the list any core values of your own which may not be listed, rating them accordingly.

1. godly church leadership

2. saving lost people

3. vibrant worship

4. biblical teachings

5. meaningful worship

6. regular private prayer

_ 7. regular corporate prayer

8. sense of community

9. family oriented fellowship

_ 10. community friendly church

_ 11. freedom of expression

_.12. independent thought

13. creativity
14. comfortable and attractive environment

_ 15. financial security

16. concern for the poor and disenfranchised

_17. a trouble-free life

18. consistency in tithing and giving

_ 19. civil rights

20. people

21. meeting new people

22. commitment

_23. compassion

_24. to be given responsibility 
_25. respect

26. ethnic diversity

27. discipline

28. teamwork

_29. allowing flexibility

_30. positive thinking

31. serving the community

32. equality
33. enthusiasm

_34. a Christian self-image

_35. God's grace

36. other:

List all the core values which have scored 4 or 5 . List no more than eight of what you consider to be your most important values. Rank them in order of priority and number them 1-8 (1 being the highest). 


\section{APPENDIX E}

\section{Outline for Seminar on Behavioral Styles}

Aim:

To increase the knowledge of the participant concerning their behavioral style.

Objective:

1) That each participant be able to identify their behavioral style and give a clear description of it to someone else.

2) To be able to identify which type of ministries best suit their behavioral style.

\section{Part One.}

Main points:

I. Introduction

Individuality

- in Scripture

- in Creation

- in Society

II. The Abstract Brain Model. Our behavior is influenced by:

- CH Cultural Heritage

- UBUnconscious Behavior

- $\mathrm{CB}$ Conscious Behavior

- A Attitudes

- V Values 
- S Skills

- K Knowledge

- E Experience

- X Expectations

- PC Physical Condition

- MC Mental Condition

III. The Behavioral Styles.

- Four Quadrant Division of Behavior

- Description of Behavioral Styles

IV. Identifying Behavioral Styles

V. Behavioral Styles and the Work Environment

VI. Administer Extended DISC Test

- Distribute Questionnaires

- Give explanation

$\underline{\text { Part Two }}$

VII. Interpreting Test Scores

VIII. Dialogue for Confirmation

IX. Application 


\section{APPENDIX F \\ Outline for Seminar in Spiritual Gifts}

Aim:

To increase the knowledge of the participant concerning their Spiritual Gifts Objectives:

- To clearly identify one's two dominant spiritual gifts

- To suggest how they are used in ministry.

I. Introduction

Understanding God's Design for Empowerment.

- What is Passion (Where)

- What is personal Style (How)

- What are Spiritual Gifts (What)

II. Spiritual Gifts Definition.

III. Gifts Mentioned in Scripture.

IV. Gifts Clusters

V. What is my Spiritual Gift?

- Administer Test.

- Dialogue for Confirmation 


\section{APPENDIX G \\ Outline for Seminar in Change of Attitude}

Aim:

The aim is to develop in the participants a positive attitude concerning involvement in the work of the local church and to create a sense of willingness to be proactive in creating opportunities for ministry.

Objectives:

- Each participant to know how to identify their own Core Values.

- Each participant to be able to understand God's Values.

I. Introduction

II. Relationship between Attitude and Behavior.

III. Definition of Attitude.

IV. Understanding "Self-talk".

V. Importance of Values and Change of Attitude.

VI. What are My Values? 
VII. Discovering God's Values.

VIII. Adopting God's Values

- Systematic Bible Study

- Meditation on the Discovery

- Prayer of Commitment

- Fellowship with Fellow Believers 


\section{APPENDIX H}

\section{Spiritual Gifts Inventory for Individuals and Congregations}

(Adapted from Dick, D. R., and Barbara Miller, Equipped for every Good Work: Building a Gift Based Church, Nashville TN: Discipleship Resources, 2001.)

For each statement, rate yourself on a scale of 1 to 7 .

7 Always

6 Almost Always

5 Often

4 Sometimes

3 Rarely

2 Almost Never

1 Never

Inventory Statements:

1. I am able to help people make choices and clarify options.

2. I am aware of things without anyone having told me about them.

3. I easily delegate authority to others.

4. I enjoy sharing my faith with the homeless and impoverished in order to give hope.

5. I enjoy teaching the Bible to a small group.

6. I believe that God will help anyone who believes in God.

7. Through prayer God miraculously works in my life.

8. I don't mind being made fun of for what I believe.

9. I am able to organise human and material resources to serve the needs of others.

10. I enjoy giving money to support the work of God.

11. I like to work with people who are considered outcasts in their communities.

12. Praying for sick people is critical for their healing.

13. I can tell when Christian groups are being honest and faithful.

14. I listen to others as carefully as I want others to listen to me.

15. I would rather be a secretary in a group than president of chairperson.

16. When sharing my faith, I ask others about their faith commitment.

17. I help others regardless of whether they are deserving or appreciative of the help.

18. I am willing to counsel people who have spiritual, emotional, or physical problems.

19. I can speak several foreign languages.

20. I can follow the conversation of a foreign language I have never studied.

21. I am good at seeing many different sides of an issue and at helping others see them as well.

22. Things I know by faith are supported later by experience or hard data.

23. When I make decisions, I stand by them. 
24. I like being part of new ministries that didn't exist before.

25. I am an effective mentor to other Christians.

26. I see God's hand at work in both good times and bad.

27. God works amazing miracles in my life.

28. Others tell me that I am a good public speaker.

29. Working with a group of ministers to the physical needs of others is more enjoyable than doing the same thing on my own.

30. I have enough money to give generously to important causes.

31. I like to visit people wherever they are: at home, in the hospital, in prison, and so forth.

32. I believe that God's healing power manifests itself in many different ways, not just in physical healing.

33. I am able to point out the flaw in logic of certain beliefs or teachings.

34. I need to talk about the things. I read in scripture and share my insights with others.

35. I am good at attending to details and doing "the busy work" that others often avoid.

36. An invitation to Christian discipleship should be extended to believers and nonbelievers whenever they worship.

37. I give practical/material assistance to people who are in need.

38. I will work hard for and support a group that is truly committed to its task.

39. Foreign languages are easy to learn.

40. I understand the meaning of foreign words and phrases.

41. Others are surprised at my depth of understanding and the soundness of my advice.

42. I sense people's moods and problems just by talking with them.

43. I am effective at organising resources to minister to others.

44. I desire the opportunity to be a missionary.

45. I feel a responsibility to point out dangerous or false teachings to others.

46. I trust that God will protect those who have lost their faith.

47. I believe that God works miracles through the faith of Christian believers.

48. I find practical applications to daily life when I read the Bible.

49. It is easy for me to ask others to help with a worthy project.

50. I feel a strong desire to give money to Christian ministries.

51. I want to help anyone I can, regardless of the reason for their need.

52. I pray for the healing of those who are sick or afflicted.

53. I know when a preacher or speaker is being true to the gospel of Jesus Christ.

54. I bothers me when people are persuaded by stories of faith that contain false teachings or wrong information.

55. I give whatever time is needed to finish a project of meet a deadline.

56. I feel comfortable telling non-Christians how important it is to believe in Jesus the Christ.

57. I prefer working in the background rather than the spotlight.

58. I am patient with people who are less mature in their spirituality

59. I communicate easily with members of other races, culture, or generations. 
60. I understand the language and attitudes of generations other than my own.

61. When others seek my advice or counsel, I am confident that my words will be sound.

62. People are surprised by how well I understand them.

63. I offer good leadership to a group or committee.

64. It is easy for me to share the gospel with other cultures that speak other languages.

65. I work to create unity and harmony within groups.

66. Regardless of the possibility or likelihood of success, I trust God's promises to be true.

67. I feel the power of the Holy Spirit when I pray.

68. My faith gives me the courage to speak out, even to people in authority.

69. I design strategies and plans for implementing ministries trough the church.

70. I know whether or not an appeal for money is legitimate.

71. My compassion for others prevents me from tending to personal needs

72. I participate in the healing of people through prayer.

73. I sense elements of truth or error in other people's teachings.

74. I enjoy creating lessons and projects that help illustrate Biblical truths.

75. Pastors and other church leaders seek my opinion on key issues.

76. I feel comfortable sharing my faith in non-Christian settings.

77. I make sure that everything runs smoothly.

78. People are willing to listen to my suggestions and criticisms because they know that I have their best interests in mind.

79. I communicate well with members of other generations

80. I am able to interpret foreign languages for others.

81. God gives me insight into the significant decisions of others.

82. Knowing what the Bible says and means gives me the answers to my problems.

83. I help others make the most of their gifts and talents.

84. I make sure that people know that I am a Christian, especially when I travel to new places.

85. I help others apply Christian principles to their lives.

86. Prayer on behalf of others channels God's power to their needs.

87. God uses me as an instrument of spiritual and supernatural power.

88. I see how biblical principles apply to today's world.

89. Others refer to me as an effective leader.

90. I seek the counsel of friends or family when I contribute to charity or church.

91. I listen to those who need someone to talk to.

92. When I pray, I deliberately include people who are physically or emotionally ill.

93. I know when a Christian leader is more self-interested than God-interested.

94. I need proof before I accept a claim as valid or true.

95. I am a better assistant than I am a leader.

96. The idea of sharing the gospel with other people excites me.

97. Serving others to make their lives easier is important to me. 
98. People go out of their way to please me.

99. I can explain western religious practices to people of different cultures.

100. I understand intuitively the meaning of foreign rituals and practices.

101. I know some things without understanding how I know them.

102. I see potential problems that others are unaware of.

103. I focus on the big picture rather than on individual details.

104. I am accepting of different lifestyles and other cultures.

105. I look for ways to help others grow as Christian disciples.

106. I spend long periods of time in prayer for others.

107. I pray for things that other people think are impossible.

108. I enjoy showing others how the Bible speaks to their life situations.

109. I enjoy supporting ministries that help the poor and needy.

110. I am a cheerful giver of money.

111. I am drawn to people who suffer physical or emotional pain.

112. When I pray for healing for myself and others, I accept that the healing that occurs might not be the one expect.

113. I know when people are speaking with the power of the Holy Spirit.

114. I understand the connection between the Old and New Testaments.

115. Being thanked is not important to me; I will continue to serve and give regardless of recognition.

116. It is important to me to lead others to Jesus Christ.

117. I am more interested in meeting the physical needs of others than in meeting their spiritual needs.

118. People seek out me opinion on personal matters.

119. I can speak a foreign language that I never formally studied.

120. I can accept the thoughts, speech, and actions of different cultures, even when the conflict with my own beliefs.

121. I have a clear sense of the right choices that other people should make.

122. My intuitions are clear and correct.

123. I work well under pressure.

124. I would like to represent the church in a foreign country.

125. When Christians loose faith, it is my duty to try to help them recover it.

126. Others tell me that I have a strong faith.

127. When I pray, I invoke God's power to change present circumstances.

128. I am committed to speaking the truth even when my stance is unpopular with others.

129. In a group, I emerge as a leader.

130. My money management abilities are of value to my church.

131. I am especially drawn to people who are suffering.

132. Others have told me that I have a healing touch.

133. I am deeply troubled by spiritualities that lack a sound theological basis.

134. I am energized and excited when I teach.

135. I enjoy making work easier for other people.

136. It is easy to invite people to make a commitment to Christ.

137. I prefer doing a job to planning a job. 
138. Others tell me that I am a good counsellor.

139. I am able to effectively communicate, in other languages, complex ideas about God.

140. I feel a close kinship with members of other cultures and traditions.

141. When I am faced with difficult choices in life, biblical applications come to mind.

142. I know when people are upset, no matter how well they try to hide it.

143. I am a good judge of other people's gifts for ministry and service.

144. I want to learn a new language in order to qualify for missionary work.

145. I enjoy working with newcomers to the Christian faith.

146. I see the image of God in everyone I meet.

147. When I pray for the health of others, there are tangible results.

148. I talk to people about salvation and heaven.

149. I like directing projects better than participating in them.

150. When I give money, I give it anonymously.

151. I reach out to people who have gotten themselves in trouble.

152. When I see people in pain, I am moved to pray for them.

153. I know when someone is not being honest.

154. I would rather read scripture or theology than Christian biographies or inspirational stories.

155. I would rather have a task defined for me than have to define it for myself.

156. I let people know what Christ has done in my life.

157. I do what is right even when it means breaking the rules.

158. I challenge people with hard truths, even if it makes me unpopular.

159. I am called to proclaim the gospel in a foreign culture or location.

160. I can translate foreign phrases into my own language automatically.

161. God allows me to see situations from God's own perspective.

162. I am able to apply biblical concepts to real-life situations.

163. I encourage people to use their gifts and talents to serve others.

164. I seek the opportunity to spread the gospel to unchurched people.

165. I assist others in their discipleship journey and spiritual growth.

166. God's promises in the Bible are still valid today.

167. I help others see God's miracles when they don't see them on their own.

168. The Bible speaks directly to the economic, social, and justice issues of our day.

169. People say that I am organised.

170. There is no limit to what I will give to help others.

171. I am very sensitive to the feelings of others.

172. I encourage people to pray for the sick and the afflicted.

173. I find inspirational messages and spiritual applications in secular books, films, or speeches.

174. I read the Bible to learn and understand God's will.

175. I prefer serving to leading.

176. I talk to nonbelievers about the Christian faith and invite them to make a commitment. 
177. I enjoy doing jobs that others consider less important.

178. I encourage dispirited and discouraged people whenever possible.

179. I have spoken a language without knowing what it was.

180. I can explain the theological thinking and teaching of foreign speakers to nonforeign-speaking people.

181. People tell me they are impressed by my insights.

182. I look at issues and situations from as many different angles as possible.

183. I enjoy managing people and resources.

184. I study other cultures and traditions with a hope that I might serve more people.

185. I want to get to know the people I serve and give aid to.

186. Even when others grow discouraged, it is easy for me to trust God.

187. My first reaction to problems or difficulties is to pray.

188. I believe that God speaks through me.

189. I experience my faith more in day-to-day living than in study, prayer, and reflection.

190. I am ready to give money to a cause I believe in.

191. Where there is sickness or suffering, I engage in the laying on of hands.

192. My faith increases when I witness the miracles of God.

193. People gain a clearer understanding of the Bible when I explain it to them.

194. I enjoy preparing Bible studies or church school lessons.

195. I make sure everything is prepared so that meetings, programmes, or services run smoothly and everyone has everything he or she needs.

196. I am more effective at sharing the gospel one-on-one than at sharing it in front of a group or crowd.

197. I minister in ways other than preaching teaching, or praying.

198. I tell others that practicing the spiritual disciplines will help their faith grow.

199. People who speak only another language understand what I am saying.

200. I feel God leading me to involvement with people of other races, cultures, or generations. 


\section{APPENDIX I}

Adapted from Dick and Miller

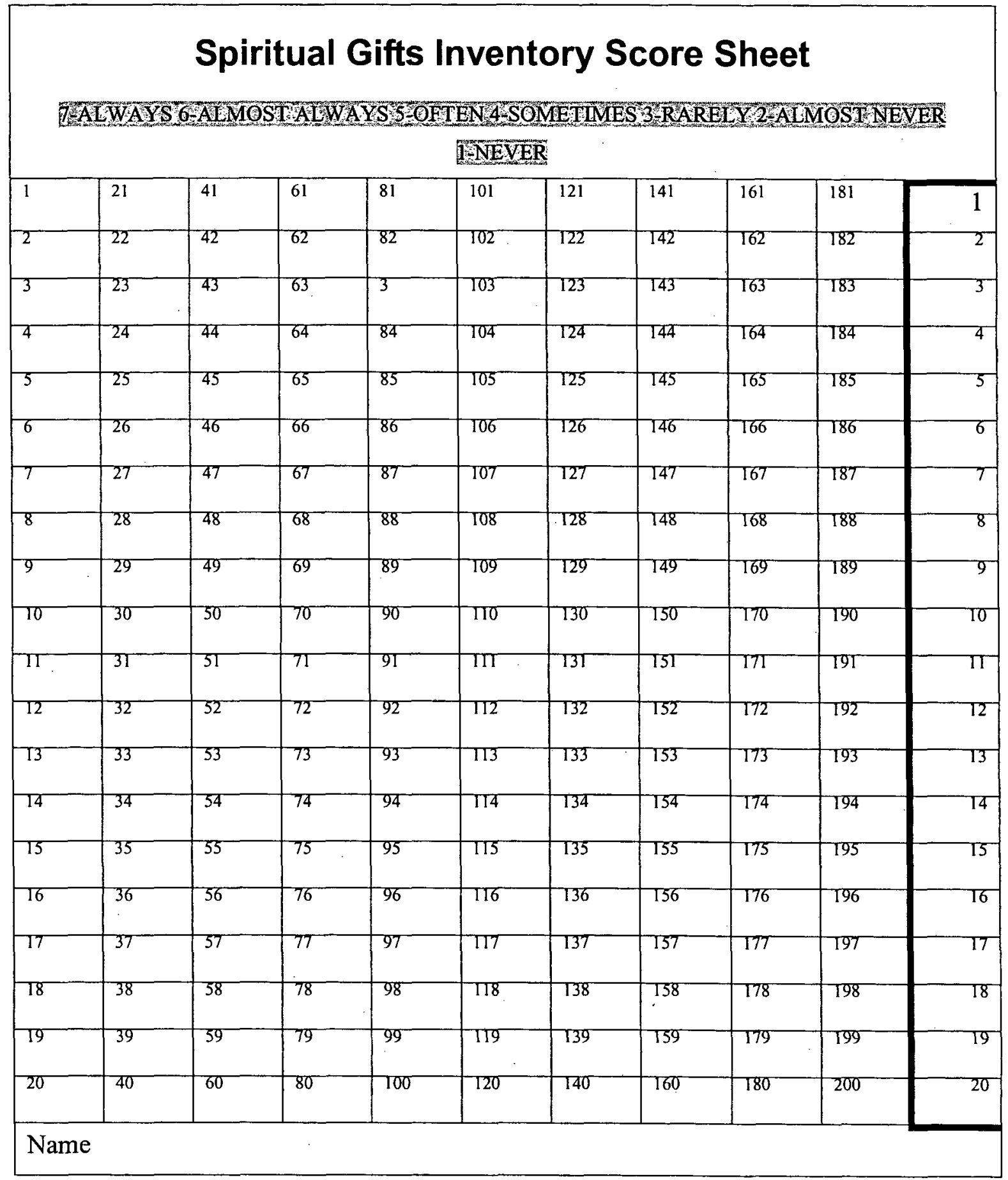




\section{APPENDIX J}

\section{Evaluation Sheet 1}

\section{Seminar in Personality Assessment}

Please respond to all questions.

1. Did you learn anything new about yourself as a result of attending this seminar?

$$
\text { Yes [ ] No [ ] }
$$

2. Are you involved in an organized ministry in the local church?

Yes [ ] No [ ]

3. Are you involved in organized ministry outside of the church? (Not organized by the local church). Yes [ ] No [ ]

4. Has the information received affected your attitude toward involvement in

$$
\text { ministry? Yes [ ] No [ ] Don't Know [ ] }
$$

5. What did you like most about this seminar?

6. What did you like the least about this seminar?

7. If this seminar were to be conducted again in the future, what changes would you recommend? 


\section{Evaluation Sheet 2}

\section{Seminar in Change of Attitude}

Please respond to all questions.

1. Did you learn anything new about yourself as a result of attending this seminar?

$$
\text { Yes [ ] No [ ] }
$$

2. Are you involved in an organized ministry in the local church?

$$
\text { Yes [ ] No [ ] }
$$

3. Are you involved in organized ministry outside of the church? (Not organized by the local church). Yes [ ] No [ ]

4. Has the information received affected your attitude toward involvement in ministry? Yes [ ] No [ ] Don't Know [ ]

5. Has this seminar help you to become more aware of you core values? Yes [ ] No [ ] Not sure [ ]

6. What did you like most about this seminar?

7. What did you like the least about this seminar?

8. If this seminar were to be conducted again in the future, what changes would you recommend? 


\section{BIBLIOGRAPHY}

Arraj, James. “Jungian Spirituality.” Spirituality Today 40 (autumn 1988): 257. Quoted in William J. Radmacher, Lay Ministry: A Theological, Spiritual, and Pastoral Handbook. New York: Crossroad, 1991.

Atkinson, J. W. An Introduction to Motivation. New York: Van Nostrand Reinhold Company, 1964.

Bacon, Francis. The Advancement of Learning. Edited by G. W. Kitchen. London: Everyman's Library, 1962.

Bauman, Zygmunt. Intimations of Postmodernity. London: Routledge, 1992.

BBC News. E-CYCLODIA. "Globalisation: What on Earth is it about?" http://news.bbc. co.uk/1/hi/special_report/1999/02/99/e-cyclopedia/711906.stm (7 October 2003).

Berger, Peter, ed. The Desecularization of the World. Resurgent Religion and World Politics. Grand Rapids, MI: Wm. B. Eerdmans Publishing Company, 1999.

Blakemore, Ken, and Margaret Boneham. Age, Race and Ethnicity: A Comparative Approach. Buckingham, UK: Open University Press, 1994.

Brierley, Peter. UK Christian Handbook Religious Trends 3 2002/2003. London: Christian Research, 2002. . UK Christian Handbook Religious Trends 4 2003/2004. London: Christian Research, 2003.

Briggs Myers, Isabel. Introduction to Type: A Guide to Understanding Your Results on the Myers-Briggs Type Indicator. Oxford, UK: Information Press, 2000.

Burke, Barry. "Post-modernism and post-modernity." http://www.infed.org/biblio/bpostmd.htm (23 November 2003).

Callinicos, Alex. Against Postmodernism: A Marxist Critique. Cambridge, UK: Polity Press, 1989. 
Campbell, W. S. "Church as Israel, People of God," In Dictionary of the Later New Testament and its Development. Edited by Ralph P. Martin and Peter H. Davids. Downers Grove, IL: InterVarsity Press, 1997, 204.

Christensen, Michael J., and Carl E. Savage, eds. Equipping the Saints: Mobilizing Laity for Ministry. Nashville, TN: Abingdon Press, 2000.

Clack, Beverley, and Brian R. Clack. The Philosophy of Religion, A Critical Introduction. Cambridge, UK: Polity Press, 2002.

Clouser, Roy A. The Myth of Religious Neutrality. London: University of Notre Dame Press, 1991.

Clowney, Edmund P. The Church, Contours of Christian Theology. Edited by Gerald Bray. Leicester, UK: Inter-Varsity Press, 1995.

Concise Oxford Dictionary of Current English, $6^{\text {th }}$ ed. Edited by J. B. Sykes. London: Book Club Associates, 1979. S.v. "Clergy."

Concise Oxford Dictionary. Edited by H. W. Fowler and F. G. Fowler. London: Book Club Associates, 1976. S.v. "Culture."

Dana, H. E., and Julius R. Mantey. A Manual Grammar of the Greek New Testament. Toronto: The Macmillan Company, 1957.

Davie, Grace. Religion in Britain Since 1945. Oxford, UK: Blackwell Publishing, 1994.

Dick, Dan R., and Barbara Miller. Equipped for Every Good Work: Building a Gift-Based Church. Nashville, TN: Discipleship Resources, 2001.

Eastwood, Cyril. The Priesthood of All Believers: An Examination of the Doctrine from the Reformation to the Present Day. Minneapolis, MN: Augsburg Publishing House, 1960.

Ewen, Robert B. An Introduction to Theories of Personality. Mahwah, NJ: Lawrence Eribaum Associates, 1998.

Exegetical Dictionary of the New Testament. Edited by Horst Balz and Gerhard Schneider. Grand Rapids, MI: Wm. B. Eerdmans Publishing Company, 1981. S.v. "kleeros."

Fenton, Steve. Ethnicity: Racism, Class and Culture. London: Macmillan Press Ltd., 1999.

Ferguson, Duncan S., ed. New Age Spirituality: An Assessment. Louisville, KY:

Westminster John Knox Press, 1993. 
Foster, Richard J. Celebration of Discipline: The Path to Spiritual Growth. San Francisco, CA: HarperCollins, 1998.

Frankl, Viktor E. Man's Search for Meaning: An Introduction to Logotherapy. Translated by Ilse Lasch. London: Hodder and Stoughton, 1982.

Fryer, Peter. Staying Power: The History of Black People in Britain. London: Pluto Press, 1984.

Giles, K. N. Dictionary of the Later New Testament and Its Development. Edited by Ralph P. Martin and Peter H. Davids. Downers Grove, IL: InterVarsity Press, 1997. S.v. "Church."

Glasser, Arthur F., Paul G. Hiebert, C. Peter Wagner, and Ralph D. Winter. Crucial Dimensions in World Evangelization. Pasadena, CA: William Carey Library, 1977.

"Gloucestershire." www.neighbourhood.statistics.gov.uk. Data supplied by 2001 Census (1 December 2004).

Godley, Andrew. Jewish Immigrant Entrepreneurship in New York and London 18801914: Enterprise and Culture. Hampshire, UK: Palgrave, 2001.

Grenz, Stanley J. A Primer for Postmoderism. Grand Rapids, MI: William B. Eerdmans Publishing Company, 1996.

Hammer, Raymond. "Approaches to Truth: The Great Interpreters." In The World Religions, eds., R. Pierce Beaver, Jan Bergman, Myrtle S. Langley, and others, 183. Hertfordshire, UK: Lion Publishing Plc., 1988.

Harper's Bible Dictionary. Edited by Paul Achtemeier. San Francisco, CA: Harper and Row Publishers, 1985. S.v. "Minister."

Hersey, Paul, and Kenneth H. Blanchard. Management of Organizational Behavior: Utilizing Human Resources, $5^{\text {th }}$ ed. Englewood Cliffs, NJ: Prentice-Hall International, Inc., 1988.

Hersey, Paul, Kenneth H. Blanchard, and Dewey E. Johnson. Management of Organizational Behavior: Leading Human Resources, $8^{\text {th }}$ ed. Upper Saddle River, NJ: Prentice Hall, Inc., 2001.

Hess, K. The New International Dictionary of New Testament Theology. Edited by Colin Brown. Grand Rapids, MI: Zondervan Publishing House, 1979. S.v. "Serve."

Hiebert, Paul. "The Flaw of the Excluded Middle." Missiology 10 (January 1982): 35. 
Hindmarsh, Bruce. "Reshaping Individualism: The Private Christian, Eighteenth Century Religion and the Enlightenement." In The Rise of the Laity in Evangelical Protestantism, ed. Deryck W. Lovegrove, 67-84. London: Routledge, 2002.

Hofstede, Geert. Culture's Consequences: Comparing Values, Behaviors, Institutions, and Organisations Across Nations, 2d ed. London: Sage Publications, 2001.

Interlinear Greek-English New Testament. Edited by Jay P. Green, Sr. Grand Rapids, MI: Baker Books, 1996.

Jackson, Edgar N. Understanding Prayer. London: SCM Press, 1980.

Jenkins, Keith. The Closed Door: A Christian's Critique of Britain's Immigration Policies. London: British Council of Churches, 1984.

Kellogg Foundation. Logical Model Development Guide. Battle Creek, MI: W. K. Kellogg Foundation, 2004.

Kruse, C. G. Dictionary of the Later New Testament and Its Development. Edited by Ralph P. Martin and Peter H. Davids. Downers Grove, IL: InterVarsity Press, 1997. S.v. "Ministry."

Kuhlman, Delcy. Experiencing God Through Spiritual Mentoring: Coming Together. Lincoln, NE: AdventSource, 1998.

Kull, Steven. "Culture Wars? How Americans and Europeans View Globalization." Brookings Review 19, no. 4 (Fall 2001): 18. Cited in http://www.questia.com/ PM.qst?action $=$ print $\&$ docId $=5000913066 j$ sessionid $=C$ n01 $(9$ June 2005).

LaHaye, Tim. Spirit-Controlled Temperament. Wheaton, IL: Tyndale House Publishers, 1966.

Leffel, Jim, and Dennis McCullum. Postmodernism and You: Religion. Cited on http://www.xenos.org/ministries/crossroads/dotrel.htm (23 November 2003).

Lewis, Philip. Islamic Britain: Religion, Politics and Identity among British Muslims. London: I. B. Tauris and Co. Ltd., 2002.

Lossky, Nicholas, Jose Miguez Bonino, John Pobee, Tom F. Stansky, Geoffrey Wainwright, and Pauline Webb, eds. Dictionary of the Ecumenical Movement. London: Council of Churches for Britain and Ireland, 1991. S.v. "Pluralism."

McDonough, Reginald M. Keys to Effective Motivation. Nashville, TN: Broadman Press, 1979. 
McNeal, Reggie. A Work of Heart: Understanding How God Shapes Spiritual Leaders. San Francisco, CA: Jossey-Bass Publishers, 2000.

Malphurs, Aubrey. Advanced Strategic Planning: A New Model for Church and Ministry Leaders. Grand Rapids, MI: Baker Books, 2000.

Maxwell, Randy. If My People Pray: An Eleventh-Hour Call to Prayer and Revival. Boise, D: Pacific Press Publishing Association, 1995.

Merton, Thomas. "Contemplative Prayer." In Celebration of Discipline: The Path to Spiritual Growth, ed. Richard J. Foster, 22. San Francisco, CA: HarperCollins, 1998.

Michael, Chester P., and Marie C. Norrisey. Prayer and Temperament. Charlottesville, NC: The Open Door, 1991.

Mulholland, M. Robert, Jr. Invitation to a Journey: A Road Map for Spiritual Formation. Downers Grove, IL: InterVarsity Press, 1993,

Muller, Karl. Dictionary of Mission: Theology, History, Perspectives. Maryknoll, NY: Orbis Books, 1987.

National Front. "The Prophecies of Enoch Powell." http://www.natfront.com/powell.html (23 November 2003).

Neill, Stephen Charles, and Hans-Ruedi Weber. The Layman in Christian History. London: SCM Press Ltd., 1963.

Oakland, John. British Civilization: An Introduction. London: Routledge, 1989.

Ogden, Greg. The New Reformation: Returning the Ministry to the People of God. Grand Rapids, MI: Zondervan Publishing House, 1990.

Parekh, Bhikhu. The Future of Multi-Ethnic Britain. London: Profile Books Ltd., 2000.

Perry, Michael. Gods Within: A Critical Guide to the New Age. London: SPCK, 1992.

Peters, Thomas J., and Robert H. Waterman, Jr. In Search of Excellence: Lessons from America's Best Run Companies. New York: Harper and Row, 1986.

Porter, D. S. A Century of Adventism in the British Isles, Messenger: Centennial Historical Special. Grantham, UK: The Stanborough Press Ltd., 1974.

Rademacher, William J. Lay Ministry: A Theological, Spiritual, and Pastoral Handbook. New York: Crossroad, 1991. 
Richards, Lawrence O. Expository Dictionary of Bible Words. Grand Rapids, MI: Zondervan Publishing House, 1985. S.v. "Minister/Ministry."

Savage, John S. The Apathetic and Bored Church Member: Psychological and Theological Implications. Reynoldsburg, OH: LEAD Consultants, Inc., 1976.

Sewell, Tony. Keep on Moving. The Windrush Legacy. London: Voice Enterprise Ltd., 1998.

Schmidt, K. L. "ekklesia." Theological Dictionary of the New Testament. Edited by Gerhard Kittle and Gerhard Friedrich. Grand Rapids, MI: Wm. B. Eerdmans Publishing Company, 1985.

Schweitzer, Cathie Ann. "Mentoring Future Professionals." JOPERD-The Journal of Physical Education, Recreation and Dance 64, no. 7 (1993): 50.

Schweizer, R. Eduard. "Ministry in the Early Church." Anchor Bible Dictionary. Edited by David Noel Freedman. London: Doubleday, 1992. 6:835.

Spencer, Nick. Asylum and Immigration: A Christian Perspective on a Polarised Debate. London: Paternoster Press, 2004.

Streng, Frederick J. Understanding Religious Man. Belmont, CA: Dickenson Publishing Co., Inc., 1969.

Swenson, Richard A. Margin: Restoring Emotional, Physical, Financial, and Time Reserves to Overloaded Lives. Colorado Springs, CO: NavPress, 1992.

Theological Dictionary of the New Testament. Edited by Gerhard Friedrich. Translated by Geoffrey W. Bromiley. Grand Rapids, MI: Wm. B. Eerdmans, 1974. S.v. "charismata."

Thomson, Rosemary. Managing People. Oxford, UK: Butterworth-Heinemann, 1993.

UK Government. Department for Culture, Media and Sport. http://www.culture.gov.uk/ about_dcms (15 October 2003).

Wagner, Hugh. The Psychobiology of Human Motivation. London: Routledge, 1999.

Wakeham, Rt. Hon. Lord. "A House for the Future: Royal Commission on the Reform of the House of Lords," 20 January 2000. http://www.archive.official-documents .co.uk (3 November 2003).

Waters, Malcolm. Globalisation. London: Routledge, 2001.

White, Ellen G. Education. Mountain View, CA: Pacific Press, 1952. 
Instruction for Effective Christian Service. Hagerstown, MD: Review and Herald Publishing Association., 1896.

. Testimonies for the Church. Vol. 2. Boise, ID: Pacific Press Publishing Association, 1948.

Whitney, Donald S. Spiritual Disciplines for the Christian Life. Colorado Springs, CO: NavPress, 1991.

Winder, Robert. Bloody Foreigners: The Story of Immigration to Britain. London: Little, Brown, 2004.

Woolford, Orville. "The 70s Struggle: A Black Perspective." Messenger-90 $0^{\text {th }}$ Anniversary Souvenir Edition 1902-1992. Grantham, UK: The Stanborough Press Ltd., 1992.

Yamauchi, E. "Synagogue." Dictionary of Jesus and the Gospels. Edited by Joel B. Green. Leicester, UK: Inter-Varsity Press, 1992.

http://www.focus.org.uk/soul (23 November 2003) and http://www.thetablet.co.uk (31 December 2003).

http://www.foreignpolicy.com/issues_janfeb_2003/countrydetail.php (7 October 2003). 
VITA

Name: $\quad$ Michael G. Hamilton

DOB: $\quad 9$ December 1957

Education:

Elementary and Secondary Education in England

B.A. Theology, Oakwood College, Huntsvillle, Alabama, USA, 1985

M.A. Religion, Andrews University, (Newbold Campus), 1987

D.Min. in Global Mission Studies, Andrews University, 2005

Professional Work:

Pastor in South England Conference, UK from 1987 to 2004.

South England Conference Ministerial Association Secretary, 2004.

Interest in Radio Ministry. 